\title{
RENATA SIMÕES
}

Influência da fragmentação de DNA espermático na produção in vitro de embriões bovinos

São Paulo 2010 


\section{RENATA SIMÕES}

Influência da fragmentação de DNA espermático na produção in vitro de embriões bovinos

Tese apresentada ao Programa de PósGraduação em Reprodução Animal da Faculdade de Medicina Veterinária e Zootecnia da Universidade de São Paulo para obtenção do título de Doutor em Ciências

Departamento:

Reprodução Animal

Área de concentração:

Reprodução Animal

Orientadora:

Prof $^{a} \quad$ Dr $^{\mathrm{a}}$ Mayra Elena Ortiz D’Ávila Assumpção 
Autorizo a reprodução parcial ou total desta obra para fins acadêmicos, desde que citada a fonte.

DADOS INTERNACIONAIS DE CATALOGAÇÃO-NA-PUBLICAÇÃO

(Biblioteca Virginie Buff D’Ápice da Faculdade de Medicina Veterinária e Zootecnia da Universidade de São Paulo)

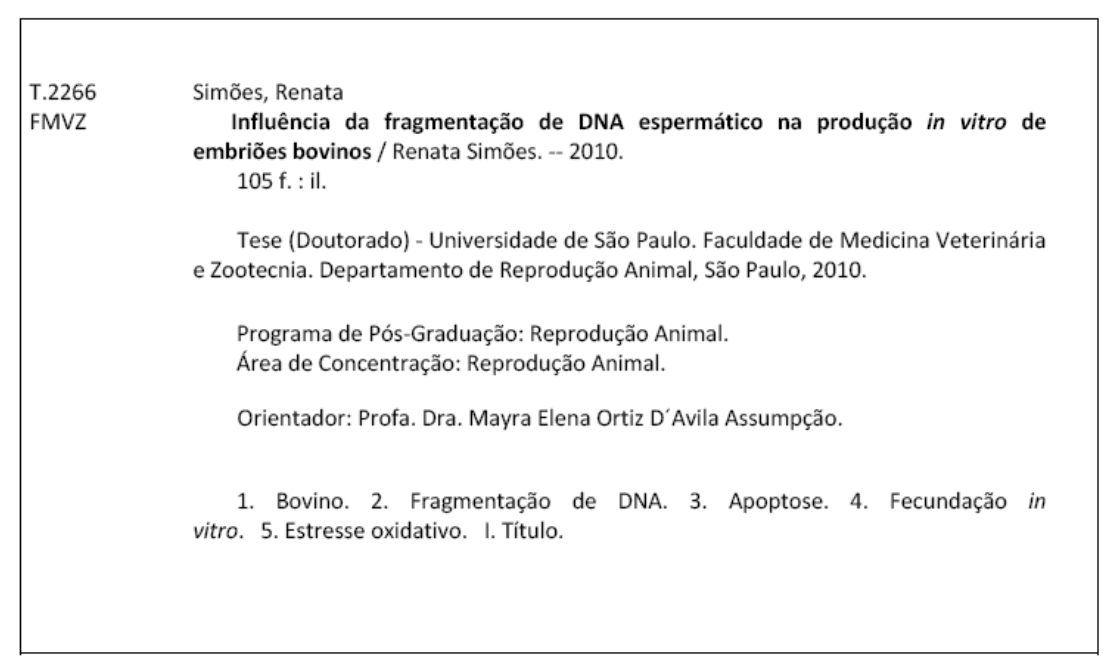


UNIVERSIDADE DE SÃO PAULO

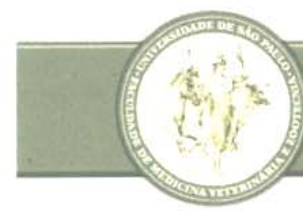

FACULDADE DE MEDICINA VETERINÁRIA E ZOOTECNIA

\section{Comissão de Ética no uso de animais}

\section{CERTIFICADO}

Certificamos que o Projeto intitulado: "Influência da fragmentação de DNA espermático na produção in vitro de embriões bovinos", protocolado sob o nº71/2007, utilizando número indefinido de bovinos, sob a responsabilidade da Profa. Dra. Mayra Elena Ortiz D’Avila Assumpção está de acordo com os princípios éticos de experimentação animal da "Comissão de Ética no uso de animais" da Faculdade de Medicina Veterinária e Zootecnia da Universidade de São Paulo e foi aprovado em reunião de 23/05/07.

We certify that the Research "Sperm DNA fragmentation influence on bovine in vitro embryo production", protocol number 1110/2007, under the responsibility Profa. Dra. Mayra Elena Ortiz D' Avila Assumpção, agree with Ethical Principles in Animal Research adopted by "Ethic Committee in the use of animals" of the School of Veterinary Medicine and Animal Science of University of São Paulo and was approved in the meeting of day $23 / 05 / 07$.

São Paulo, 18 de março de 2010

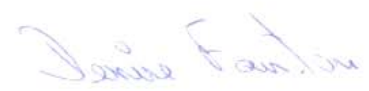

Profa Dra Denise Tabacchi Fantoni

Presidente 


\section{FOLHA DE AVALIAÇÃO}

Nome: SIMÕES, Renata

Título: Influência da fragmentação de DNA espermático na produção in vitro de embriões bovinos

Tese apresentada ao Programa de PósGraduação em Reprodução Animal da Faculdade de Medicina Veterinária e Zootecnia da Universidade de São Paulo para obtenção do título de Doutor em Ciências

Data:

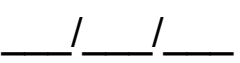

\section{Banca Examinadora}

Prof. Dr.

Instituição:

Assinatura:

Julgamento:

Prof. Dr.

Instituição:

Assinatura:

Julgamento:

Prof. Dr.

Assinatura:

Instituição:

Julgamento:

Prof. Dr.

Instituição:

Assinatura:

Julgamento:

Prof. Dr.

Instituição:

Assinatura:

Julgamento: 
À minha avó Teca e minha mãe Christina, meus anjos da guarda, pela dedicação, paciência e pelo amor incondicional.

Ao meu marido Giuliano, meu porto seguro, pela lealdade, carinho, dedicação, amor e por sempre acreditar em mim. 


\section{MEUS SINCEROS E ETERNOS AGRADECIMENTOS...}

À minha mãe, Christina, por ter me dado a vida e me ensinado a vivê-la com dignidade. Por ter iluminado meus caminhos com sabedoria e dedicação para que eu trilhasse sem medo e cheia de esperança. Pela renúncia dos seus sonhos para que, muitas vezes pudesse realizar os meus. Pela compreensão durante minha ausência e pelo "colo de mãe" sempre que necessário. Te amo eternamente!!

À minha vó, Teca, pelo amor incondicional e por todas as "velinhas"... e quantas foram nestes últimos anos... Sempre presente e torcendo pelo meu sucesso. Vó, não tenho palavras para agradecer tanto amor e dedicação.

As minhas irmãs, Fernanda e Adriana, pelo companheirismo e amizade. Pela lealdade, pelo carinho, por vibrarem comigo nas vitórias e por dividirem comigo os momentos mais difíceis.

Ao meu pai por escolha, Virgilio, que sempre alegra os meus dias com seus telefonemas "trote"... pelos seus "sábios" ensinamentos e que mesmo com a distância sempre esteve presente com um sorriso e um carinho imenso. Gutchão, obrigada por fazer parte da minha vida.

Ao meu marido, Giuliano, por me apoiar incondicionalmente. Por ser meu amigo, meu marido e meu eterno namorado.... Nego, obrigada por aturar meu mau humor, minhas angústias, meus choros, minha ansiedade, minha ausência e por viver intensamente comigo todas as vitórias. Não sei como agradecer por tanta paciência, dedicação, lealdade e respeito. Obrigada por estar sempre ao meu lado, segurando a minha mão. Te amo!!!

À Fubá, uma das coisas mais gostosas que aconteceram no ano passado. Afinal, "não há nenhum psiquiatra no mundo igual a um cachorro que lambe sua face".

À Regina, Glorinha e meu pai, Oswaldo, pelo apoio e incentivo durante essa longa caminhada.

Aos meus cunhados e amigos, Deda, Fábio, Fabrízio, Luis e Maurizio pelas muitas conversas, inúmeras risadas, churrascos e carinho. Valeu!! Vocês são impagáveis!!!!

Aos amigos e colegas do Laboratório, Adriano, Camilla, Everton, Fabíola, Fê, Flá, Giana, Julia, Marcinha, Mari Giassetti, Mari Groke, Mari Queiroz, Maza, Paulo, Pedro, Samir, Weber e Zeca, pela colaboração no projeto, apoio, incentivo e momentos de descontração eternos. "Essa família é muito unida..."

Às amigas da faculdade, Clau, Ju, Luzinha, Mari, Paulinha e Pê, pelos "clubes da Lulu" e apoio mesmo que distante. Adoro vocês!!

Às amigas, Alê Nicacio, Flá, Lindsay e Mari Groke pela amizade, paciência, compreensão, puxões de orelha, carinho, colo, risadas, baladas, incentivo, 
torcida e apoio nas horas mais necessárias e difíceis. Não sei o que seria de mim sem vocês...

Aos amigos Adriano, Marcilio e Mari Groke pela maior demonstração de amizade e profissionalismo. Como será que teria sido esta reta final sem vocês? Com certeza eu não teria conseguido fazer tudo isso sem vocês. Obrigada por passarem tantas noites no laboratório junto comigo... por compartilharem todos os meus momentos de desespero e me mostrarem que no fim tudo dá certo... pelos almoços aos sábados (Gato, você é quem brilha!!!), pelos lanches nas madrugadas, por quase me matar de frio (né, Adriano??!!!), pelas eternas discussões sobre assuntos aleatórios (né, Mari???!!) e também sobre o projeto, por abrirem mão dos seus finais de semana e horas de sono só para me ajudar nos loucos dias de FIV. Vocês são muito especiais!!!

Aos amigos Camilla, Maran e Edu, por me ajudar a superar meus "medos" e a desvendar os "mistérios" do citômetro e pelas análises dos dados sempre feitas rapidamente e principalmente pela paciência.

Aos amigos de Departamento, Camila (Tralha), Carlinha, Claudinha, Cris, Eduardo, Henderson, Liege, Manoel, Paola, Robertinha, pelas conversas, pelos almoços sempre cheios de risadas, pelas baladas, churrascos e por sempre tornar todos os meus dias mais divertidos.

À minha orientadora $\operatorname{Prof}^{a} \operatorname{Dr}^{a}$ Mayra Elena Ortiz D'Ávila Assumpção. Má... é tão difícil transcrever em poucas palavras todo o carinho e respeito que tenho por você durante estes oito anos de amizade... Obrigada por ser meu porto seguro e minha mãe quando necessário. Obrigada por toda a confiança, pelo carinho e por me aceitar mais uma vez como parte da sua equipe. Obrigada pela confiança com os seus filhos (Xi e João)... nunca vou esquecer de todas as tentativas de fazer os dois comerem, dos sorrisos e dos abraços mais gostosos do mundo!!! Não tenho como te agradecer por muitas vezes você ter deixado as suas coisas de lado e até algumas horas de sono para corrigir meus trabalhos e conversar sobre assuntos pessoais. Obrigada por me ensinar a perseguir os meus sonhos e nunca desistir, mesmo quando os caminhos são tortuosos. Talvez, em alguns momentos, tenha sido muito difícil não ter você ao meu lado, mas hoje tenho certeza que sou uma pessoa muito mais madura em todos os sentidos... e isso eu devo à você!!!

Ao Prof. Dr. José Antônio Visintin, por ser um dos grandes "culpados" de tudo isso. Obrigada por sempre me nortear, por "comprar brigas" junto comigo, por me dar bronca nos momentos de fraqueza e por ser muitas vezes o meu pai... Obrigada por todas as oportunidades e ensinamentos. Você é o meu exemplo de superação, de força, de vontade, de profissionalismo e de amigo. Você me ensinou a ouvir NÃO e transformá-lo em garra e determinação para alcançar os meus sonhos. Agora é a minha vez de te dizer NÃO.... Visintin, NÃO esquecerei jamais, nunca tudo o que você fez por mim.... tudo o que você fez para permitir que agora eu estivesse aqui concluindo mais esta etapa. Serei eternamente grata. 
Aos amigos André (Cachaço) e Ricardo (Snarf) pelas inúmeras discussões sobre o projeto. Pelas sugestões e pela paciência sempre que eu ligava ou mandava email com alguma dúvida. Haja paciência... Ninguém mandou ser tão solícito!!!

À Prof $^{\mathrm{a}} \mathrm{Dr}^{\mathrm{a}}$ Valquíria Hyppolito Barnabe pelo uso do Laboratório do Departamento de Reprodução Animal da FMVZ-USP para as dosagens de TBARS.

Às Centrais de Coleta e Processamento de Sêmen Bela Vista, Lagoa da Serra, VR e aos colegas Marco Antônio e Eduardo Grandal (GMG e Xenetica Fontao, Espanha) pela doação das doses de sêmen para este projeto.

À Dona Silvia pelos chás, cafés e carinho de todos os dias.

Ao Irailton (Ira), Miguel, Luis e Belau, por estarem sempre dispostos a ajudar.

À Harumi, Thaís e Alice, pela ajuda burocrática e compreensão.

À todos os funcionários da biblioteca, principalmente a Elza Faquim.

Ao Departamento de Reprodução Animal (VRA), minha segunda casa... ou será que é minha primeira casa???!!! Já nem sei mais.... O melhor lugar para trabalhar e fazer amigos... o único lugar onde todos são profissionais e apesar de tantas diferenças, todos vestem a mesma camisa... a única coisa ruim é que um dia a gente tem que colocar o pé na estrada e sair deste mundo... Sentirei saudades eternas!!!!

Ao Frigorífico Angelelli (Piracicaba-SP), pelos milhares de ovários cedidos para este experimento.

À Fundação de Amparo à Pesquisa do Estado de São Paulo (FAPESP), pela concessão da bolsa de Doutorado (Processo 07/55294-8).

Ao Prof. Dr. Pietro Sampaio Baruselli, chefe do Departamento de Reprodução Animal, pela oportunidade. 


\title{
Meus longos e bons anos no doutorado....
}

\author{
O mestrado acabou, \\ o doutorado começou, \\ a FAPESP não aprovou, \\ e agora, Renata? \\ e agora, Renata? \\ você se esforçou, \\ o Weber ajudou \\ a Mayra justificou \\ a FAPESP entendeu \\ e agora, Renata? \\ Está sem touro, \\ está sem protocolo, \\ está sem rumo, \\ já não pode parar, \\ já não pode esperar, \\ desesperar já não pode, \\ alguns emails enviou, \\ a viagem veio \\ o sêmen veio, \\ não veio o resultado \\ a Marcella opinou, \\ o Giuliano ajudou, \\ e tudo funcionou \\ e agora, Renata? \\ E agora, Renata? \\ você se esforçou, \\ você trabalhou, \\ o resultado conseguiu \\ a publicação saiu, \\ a qualificação aconteceu, \\ o projeto mudou, \\ e o ano acabou, \\ e agora?
}

\author{
Novo projeto na mão \\ novo rumo, \\ não tem mais sêmen, \\ quer morrer de angústia, \\ mas a Mari Groke acalmou; \\ a Flavia ajudou, \\ o Visintin incentivou, \\ chegou mais sêmen \\ Renata, e agora?
}

Se a Camilla não ensinasse, Se a Maran não analisasse, Se a Fabíola não ajudasse, a estatística não existiria, se a Fernanda não acompanhasse

se a Marcinha não cooperasse se os ovários o Zeca não buscasse se você enlouquecesse.... Mas você não enlouquece, você é forte, Renata!

Sozinha? Nunca!

Com a Julia na aspiração, com o Everton na MIV, com a Giassetti no preparo, com o Pedro na FIV, com o Marcilio no TBARS com a Xumbada na lavagem com a Giana na embalagem

E se a noite chegasse? churrasco o Paulo faria o Adriano gargalharia o projeto acabaria e você agradeceria.

E chegaria o dia da defesa, Renata! E agora, Renata? Para onde? 


\section{RESUMO}

SIMÕES, R. Influência da fragmentação de DNA espermático na produção in vitro de embriões bovinos. [Sperm DNA fragmentation influence on bovine in vitro embryo production]. 2010. 105f. Tese (Doutorado em Ciências) - Faculdade de Medicina Veterinária e Zootecnia, Universidade de São Paulo, São Paulo, 2010.

A integridade da cromatina espermática é fundamental para a transmissão das informações genéticas paternas, sendo que alterações de DNA podem levar a falhas no processo reprodutivo. Danos na cromatina espermática podem ocorrer por diversos motivos, sendo que os mais importantes são a apoptose, a deficiência de protamina e os danos causados pelas espécies reativas de oxigênio (EROs). Os danos de DNA espermático não impedem que o espermatozóide fecunde o oócito, entretanto podem causar perda embrionária por apoptose. A importância da integridade da cromatina espermática no desenvolvimento embrionário já foi descrita em humanos, sendo que pode ser atribuída como uma das causas de infertilidade masculina, quando está alterada. Contudo, as informações sobre a influência da integridade do DNA espermático no processo de fecundação e do desenvolvimento embrionário na espécie bovina são muito escassas. Devido à falta de informação sobre a relação da fragmentação de DNA e conseqüente alteração nos índices de desenvolvimento embrionário nessa espécie, este trabalho teve como objetivo avaliar o índice de fragmentação de DNA espermático em uma população de touros e verificar a influência dos possíveis danos de DNA espermático na produção in vitro (PIV) de embriões. Para isto, o sêmen congelado de 221 touros foi avaliado pelo ensaio de estrutura de cromatina espermática (SCSA). Após o ensaio, os animais foram divididos em seis grupos experimentais de acordo com o índice de fragmentação de DNA apresentado, sendo sete animais de cada grupo, escolhidos aleatoriamente para as avaliações espermáticas: motilidade, fragmentação de DNA espermático pelos ensaios SCSA e Cometa Alcalino e estresse oxidativo pelo ensaio de substâncias reativas ao ácido tiobarbitúrico (TBARS). Posteriormente foi realizada a PIV de 
embriões, sendo avaliados os índices de clivagem e de blastocisto e realizado o ensaio de TUNEL para a avaliação da apoptose dos blastocistos produzidos. Em relação à motilidade espermática, o grupo 1 apresentou menor motilidade em relação ao grupo $4(p<0,05)$. Não foi verificada diferença significativa da motilidade entre os outros grupos experimentais. $O$ ensaio SCSA revelou que o grupo 1 apresentou menor susceptibilidade à fragmentação de DNA espermático quando comparado com o grupo 5 $(p<0,05)$. O grupo 2 apresentou susceptibilidade à fragmentação de DNA espermático inferior, quando comparado aos grupos $3,4,5$ e $6(p<0,05)$. Em relação ao ensaio Cometa Alcalino, a avaliação do estresse oxidativo e a PIV de embriões, não houve diferença significativa entre os grupos experimentais. Além disso, foi observada correlação negativa entre a intensidade média do Cometa e o índice de blastocisto produzido in vitro. $\mathrm{O}$ índice de blastocisto também apresentou correlação negativa com a intensidade média da cabeça do Cometa e ao ensaio TBARS. O ensaio TBARS apresentou correlação negativa com o índice de clivagem dos embriões PIV. Por outro lado, o ensaio TBARS apresentou correlação positiva com os ensaios SCSA e TUNEL. Considerando as condições experimentais, a fragmentação de DNA espermático não influenciou a PIV de embriões bovinos.

Palavras-chave - bovino, fragmentação de DNA, apoptose, fecundação in vitro, estresse oxidativo 


\section{ABSTRACT}

SIMÕES, R. Sperm DNA fragmentation influence on bovine in vitro embryo production [Influência da fragmentação de DNA espermático na produção in vitro de embriões bovinos]. 2010. 105f. Tese (Doutorado em Ciências) - Faculdade de Medicina Veterinária e Zootecnia, Universidade de São Paulo, São Paulo, 2010.

Sperm chromatin integrity is essential for the transmission of paternal genetic information. Changes in sperm DNA can lead to failures in the reproductive process. Loss of chromatin integrity may occur for several reasons, and the most important are apoptosis, protamine deficiency and damages caused by reactive oxygen species (ROS). The sperm DNA damage does not prevent the sperm to fertilize the oocyte, however it can cause embryonic loss by apoptosis. The importance of sperm chromatin integrity in embryonic development has been described in humans, and can be considered a cause of male infertility when it is disrupted. However, information on the influence of sperm DNA integrity in the process of fertilization and embryonic development in cattle are very scarce. Due to the lack of information on the relationship between DNA fragmentation and its consequence on embryonic development rates in this species, this study aimed to evaluate the sperm DNA fragmentation rate in a population of bulls and the influence of possible sperm DNA damage on in vitro production (IVP). For this, frozen semen from 221 bulls was evaluated by sperm chromatin structure assay (SCSA). After that, animals were divided into six groups, according to the DNA fragmentation rate observed. Then seven animals from each group were randomly chosen for sperm evaluation: motility, sperm DNA fragmentation by the SCSA and Alkaline Comet assay and oxidative stress by tiobarbituric acid reactive substances (TBARS). After sperm evaluations embryo IVP was performed. Cleavage and blastocyst rates were assessed and the obtained blastocysts were submitted to TUNEL assay for apoptosis evaluation. Regarding sperm motility, group 1 had lower motility compared to group 4 ( $p<0.05)$. There was no significant difference in motility between the other experimental groups. The SCSA revealed that 
group 1 showed lower susceptibility to sperm DNA fragmentation when compared to group 5 ( $p<0.05$ ). Group 2 was less susceptible to sperm DNA fragmentation, when compared to groups $3,4,5$ and $6(p<0.05)$. For the alkaline comet assay, the assessment of oxidative stress and embryo IVP, no significant difference was shown between en experimental groups. Moreover, there was a negative correlation between the comet mean intensity and the blastocyst rate. The blastocyst rate also negatively correlated to the comet head mean intensity and TBARS. The TBARS was negatively correlated to cleavage rate. In addition, TBARS correlated positively to TUNEL assay and SCSA. Considering the experimental conditions, the sperm DNA fragmentation did not influence the IVP of bovine embryos.

Keywords - bovine, DNA fragmentation, apoptosis, in vitro fertilization, oxidative stress 
SUMÁRIO

1 INTRODUÇÃO

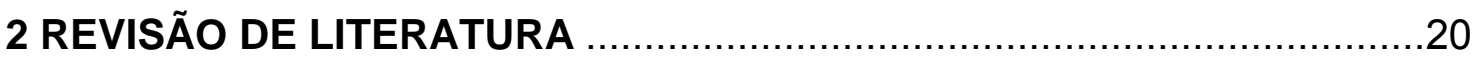

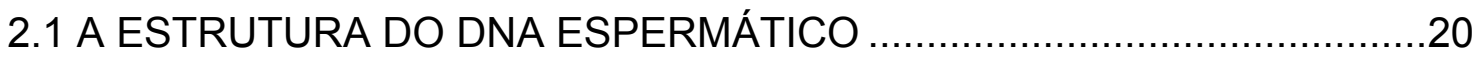

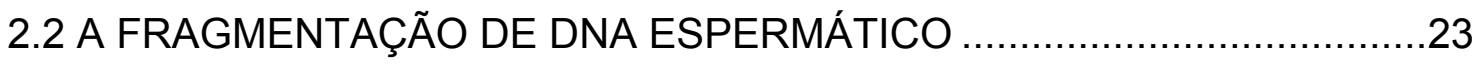

2.2.1 Fragmentação de DNA espermático por apoptose na

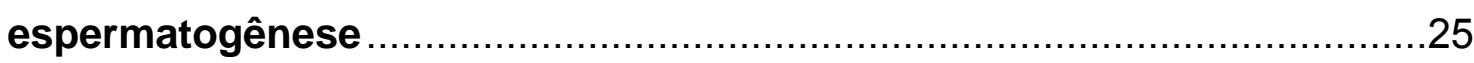

2.2.2 A fragmentação de DNA espermático por deficiência de

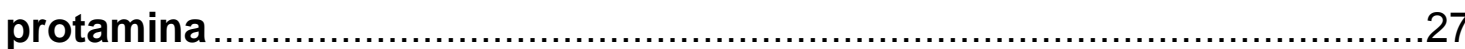

2.2.3 A fragmentação de DNA espermático por espécies reativas de

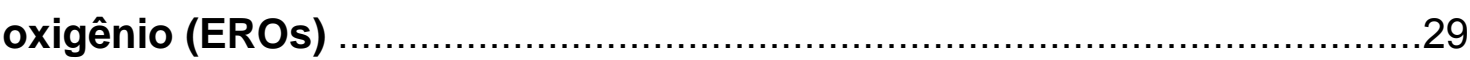

2.3 A FRAGMENTAÇÃO DO DNA ESPERMÁTICO E O DESENVOLVIMENTO EMBRIONÁRIO INICIAL..........................................32

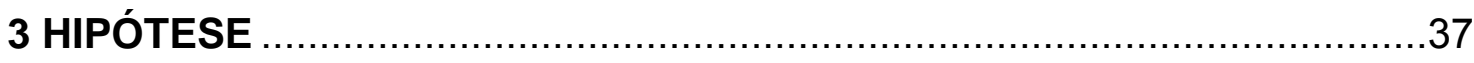

4 OBJETIVOS

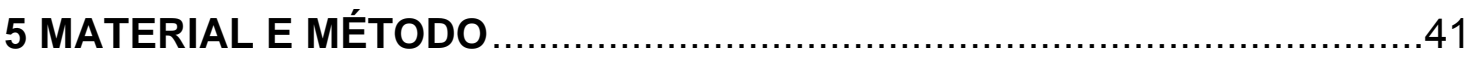

5.1 EXPERIMENTO 1: AVALIAÇÃO DO ÍNDICE DE FRAGMETNAÇÃO DE DNA ESPERMÁTICO DE UMA DETERMINADA POPULAÇÃO DE TOUROS

5.1.1 Avaliação da susceptibilidade da fragmentação de DNA espermático pelo Ensaio de Estrutura de Cromatina Espermática SCSA para a divisão dos grupos experimentais .................................... 41

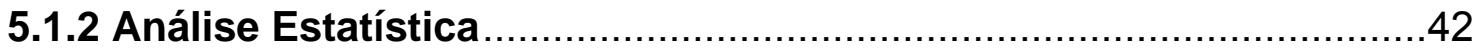

5.2 EXPERIMENTO 2: INFLUÊNCIA PATERNA NA PRODUÇÃO IN VITRO

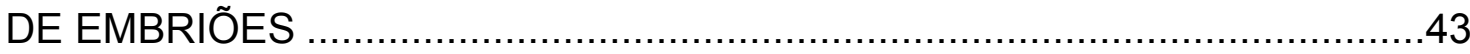

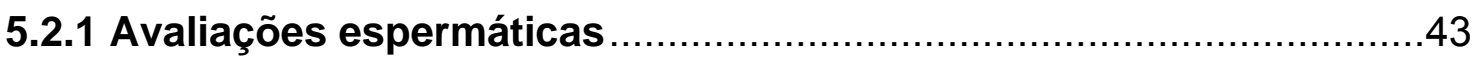

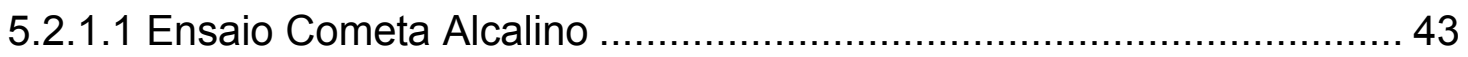

5.2.1.2 Ensaio de substâncias reativas ao ácido tiobarbitúrico - TBARS ....... 47

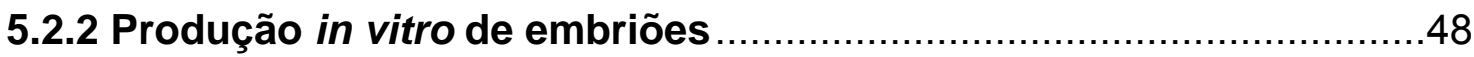

5.2.2.1 Obtenção e maturação in vitro (MIV) dos oócitos.............................. 48

5.2.2.2 Fecundação in vitro (FIV) e culitivo embrionário (CIV) ...................... 49

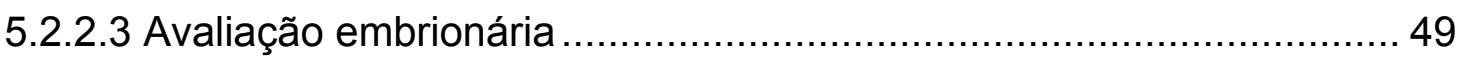




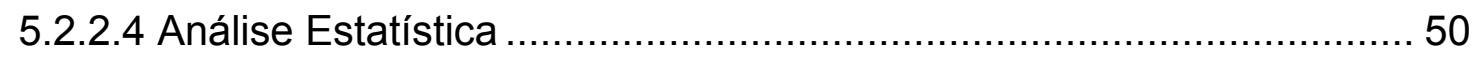

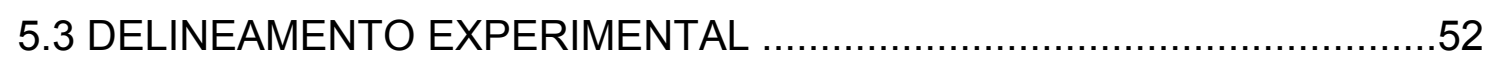

6 RESULTADOS

6.1 EXPERIMENTO 1: AVALIAÇÃO DA SUSCEPTIBILIDADE DA FRAGMENTAÇÃO DE DNA ESPERMÁTICO PELO ENSAIO DE ESTRUTURA DE CROMATINA ESPERMÁTICA (SCSA) PARA A DIVISÃO

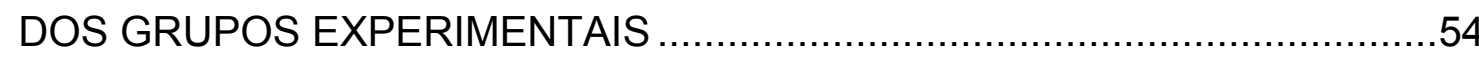

6.2 EXPERIMENTO 2: INFLUÊNCIA PATERNA NA PRODUÇÃO IN

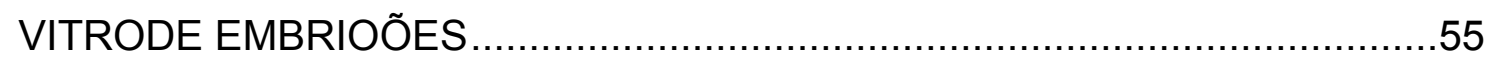

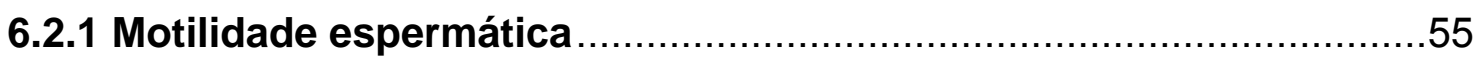

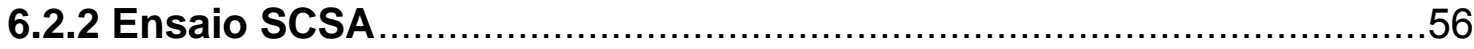

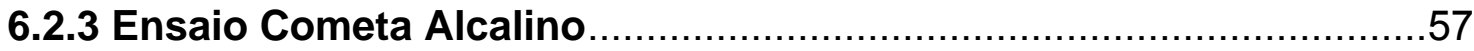

6.2.4 Ensaio de substâncias reativas ao ácido tiobarbitúrico - TBARS ....59

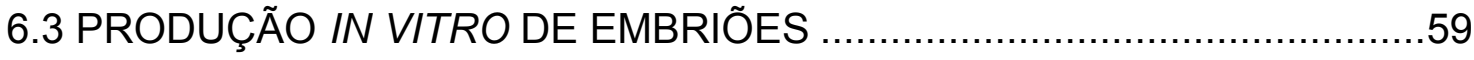

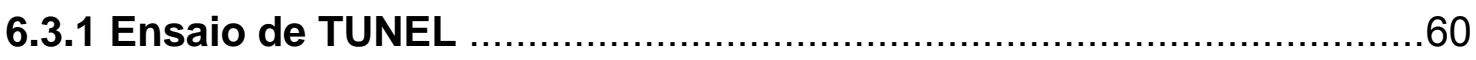

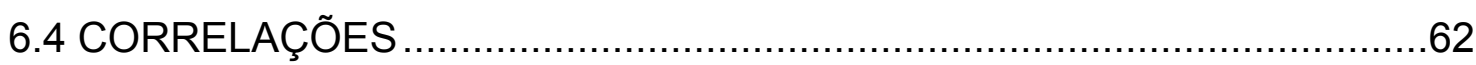

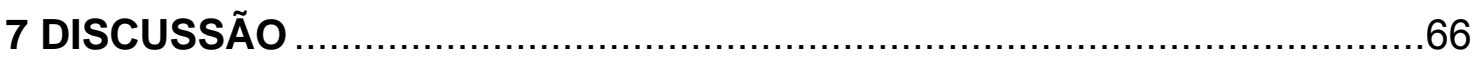

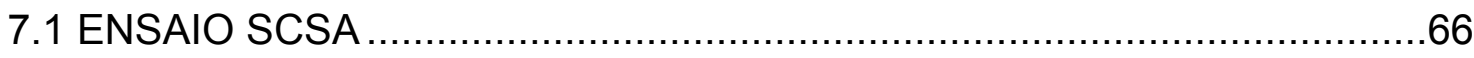

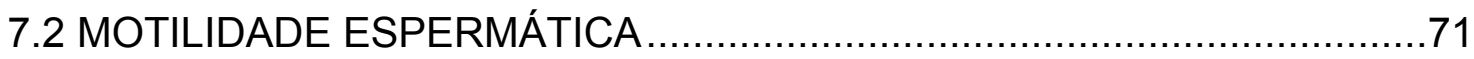

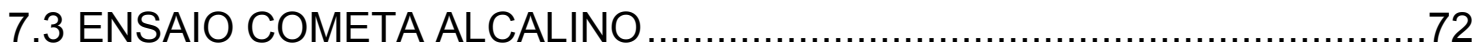

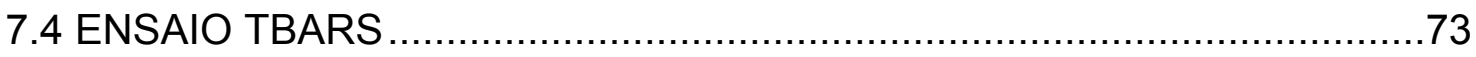

7.5 PRODUÇÃO IN VITRO DE EMBRIÕES ..............................................

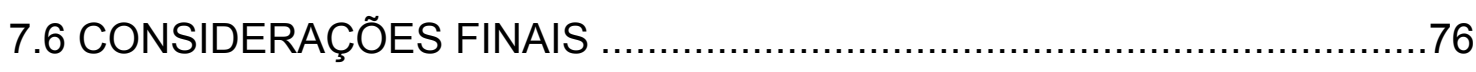

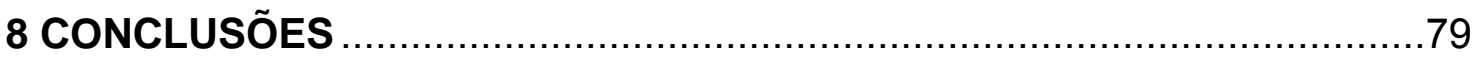

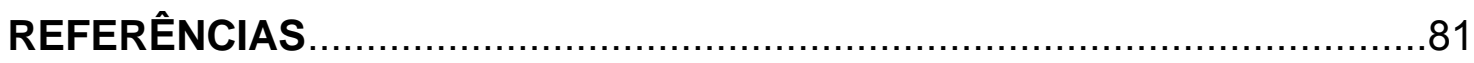

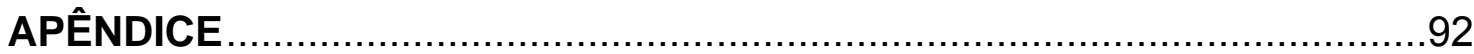

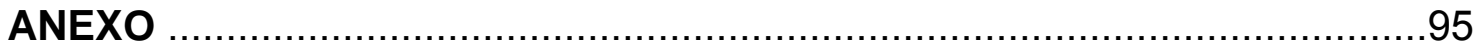




\section{INTRODUÇÃO}

A eficiência reprodutiva dos animais domésticos é uma das maiores preocupações econômicas para a pecuária mundial. Segundo Sreenan e Diskin (1983), aproximadamente $90 \%$ do sucesso reprodutivo pode estar relacionado ao índice de fecundação e ao desenvolvimento embrionário inicial. Sendo assim, um dos principais fatores que pode afetar tanto a fecundação como o desenvolvimento embrionário é a qualidade seminal.

A qualidade do sêmen é normalmente determinada segundo a concentração, a motilidade e a morfologia dos espermatozóides. Entretanto, já foi descrito baixa correlação entre as características seminais e a fertilidade (ROCHA et al., 2002; ERENPREISS et al., 2006) sugerindo que as causas de baixa fertilidade possam estar relacionadas a alterações das membranas espermáticas (plasmática e acrossomal) ou da cromatina desta célula.

Com o uso das biotecnologias da reprodução, a seleção natural dos espermatozóides que acontece durante o trajeto no trato genital feminino, não ocorre, permitindo que espermatozóides com diversos tipos de anomalias sejam utilizados para a produção in vitro (PIV) de embriões. Aproximadamente 20-40\% dos oócitos selecionados para maturação in vitro (MIV) atingem o estádio de blastocisto (PALMA; SINOWATZ, 2004). Diversos fatores como a qualidade do oócito, o sistema de co-cultivo, os meios de cultura, a concentração de oxigênio, a densidade embrionária e os substratos energéticos podem afetar os índices de implantação dos embriões PIV (KHURANA; NIEMANN, 2000).

Além dos fatores oocitários e intrínsecos ao cultivo embrionário, a importância do espermatozóide não deve ser deixada de lado. O espermatozóide não pode ser considerado meramente como um vetor do DNA paterno, pois também carrega fatores citoplasmáticos que são essenciais para o início do desenvolvimento embrionário normal. Além disto, alterações no material genético do espermatozóide podem acarretar a diminuição dos índices de desenvolvimento embrionário (ERENPREISS et al., 2006).

A avaliação do DNA espermático tem sido destacada na literatura como essencial para o sucesso do desenvolvimento embrionário. $O$ efeito biológico 
dos danos presentes na cromatina do espermatozóide é uma combinação da extensão das alterações no DNA espermático com a capacidade do oócito em reparar estes danos pré-existentes (EVENSON; LARSON; JOST, 2002). O oócito tem a capacidade de reparar danos no DNA do espermatozóide, entretanto esta capacidade é limitada. Espermatozóides que apresentam danos de DNA não perdem a capacidade de fecundar o oócito, ocorrendo a ativação do genoma paterno e o desenvolvimento embrionário inicial, entretanto este é bloqueado nos primeiros estádios ou há perda fetal precoce (FATEHI et al., 2006).

Em humanos, os testes envolvendo análise de cromatina espermática têm sido utilizados rotineiramente em clínicas de reprodução assistida para evitar falhas de fecundação e perda embrionária (ESTERHUIZEN et al., 2000; ENCISO et al., 2006). Ao contrário da reprodução humana assistida, o sêmen utilizado na PIV de embriões bovinos provém de animais de genética comprovada; entretanto, os índices de desenvolvimento embrionário ainda são inferiores aos resultados obtidos in vivo e podem estar relacionados não apenas com a qualidade do oócito e meios de cultivo, mas também com fatores intrínsecos ao espermatozóide (COMIZZOLI et al., 2000).

Devido ao fato da fragmentação de DNA espermático não alterar os parâmetros avaliados na análise seminal de rotina e não impedir que estas células defeituosas fecundem um oócito, testes de avaliação da integridade de DNA espermático devem ser empregados antes da utilização do sêmen, evitando assim, possíveis perdas embrionárias precoce, o desperdício do material genético da fêmea e os custos com a PIV de embriões. Além disso, pouco se sabe sobre a influência da fragmentação de DNA espermático na capacidade fecundante de espermatozóides e no desenvolvimento embrionário in vitro na espécie bovina. 


\section{Revisão de Literatura}




\section{REVISÃO DE LITERATURA}

Diversos trabalhos têm destacado a importância do espermatozóide no processo de fecundação. Atualmente já se sabe que existe grande interação entre o espermatozóide e o oócito, levando à ativação do gameta feminino e à descondensação da cabeça do espermatozóide. Muitas estruturas, organelas e moléculas presentes na célula espermática parecem ser críticas para o sucesso da fecundação e o desenvolvimento embrionário normal (BARROSO et al., 2009).

A influência paterna no desenvolvimento embrionário pode ocorrer no período pré-implantacional. Em um estudo realizado por Tesarik, Greco e Mendonza (2002) foi observado que a influência paterna no início do desenvolvimento embrionário pode estar relacionada à deficiência de fatores de ativação oocitária oriundos do espermatozóide. As alterações nesta fase coincidem com a fase de menor expressão de genes paternos. Isso pode explicar a não influência da qualidade da cromatina espermática nesta fase do desenvolvimento embrionário. Por outro lado, em estádios mais avançados, quando ocorre a ativação do genoma embrionário, danos de DNA e alterações de empacotamento da cromatina espermática, podem afetar a expressão de genes paternos e consequentemente, o desenvolvimento embrionário (TESARIK et al., 2005).

\subsection{A ESTRUTURA DO DNA ESPERMÁTICO}

A espermatogênese é o processo de produção de espermatozóides a partir da espermatogônia e apresenta duração média de 61 dias em bovinos. A espermatocitogênese e a espermiogênese são os dois principais eventos da produção de espermatozóides. A espermatocitogênese tem duração média de 44 dias e inclui divisões mitóticas e meióticas da espermatogônia, originando os espermatócitos primários, secundários e posteriormente, as espermátides. A espermiogênese se estende, em média, por 17 dias e compreende as 
alterações morfológicas da espermátide redonda, dando origem ao espermatozóide maturo (AMANN, 1983).

A cromatina dos espermatozóides maduros difere em composição e estrutura da cromatina das células somáticas (ROCHA et al., 2002; McLAY; CLARKE, 2003). Durante a espermiogênese, as histonas, que são proteínas nucleares responsáveis pela compactação da cromatina das células somáticas são substituídas por nucleoproteínas específicas chamadas protaminas. Estas proteínas constituem aproximadamente $85 \%$ das nucleoproteínas presentes no espermatozóide e o restante da cromatina espermática (15\%) continua associada às histonas (SINGH et al., 2003).

De acordo com Carrell, Emery e Hammoud (2007), a cromatina das espermátides tem estrutura similar àquela presente nas células somáticas e apresentam alta atividade transcricional. Nos estágios iniciais da espermiogênese ocorre o processo de substituição das histonas por protaminas (protaminação). Durante este processo, as histonas são hiperacetiladas e os nucleossomos dissociados. O DNA sofre remodelação e no lugar das histonas há ligação de proteínas de transição (PTs). No final da espermiogênese, as PTs são substituídas pelas protaminas, que por sua vez, se ligam à curvatura menor do DNA (WOUTERS-TYROU et al., 1998). Segundo Rocha et al. (2002), após a ligação desta proteína, a cromatina espermática apresenta-se extremamente condensada e inerte, devido a neutralização do esqueleto fosfodiéster do DNA pela interação dos resíduos amina da protamina com grupos fosfatos das fitas do DNA. Esta ligação núcleo-proteína é estabilizada durante a maturação espermática no epidídimo devido a formação de pontes dissulfídicas quando ocorre a conversão das pontes -SH para -S-S- das protaminas (BIANCHI et al., 1993).

Apesar de diversos mamíferos apresentarem o DNA espermático ligado às protaminas, algumas diferenças são encontradas entre espécies. $A$ protamina 1 (P1) é expressa em todos os mamíferos (CARRELL et al., 2007) enquanto que a protamina 2 (P2) só foi descrita em espermatozóides humanos e murinos. Segundo Maier et al. (1990), a P2 em bovinos e suínos não é funcional. Estes autores acreditam que somente a P1 possa ser responsável pela compactação da cromatina e que a P2 sofra degradação durante as últimas etapas da espermiogênese. Mutações pontuais no gene da P2, que na 
espécie bovina, ganha aminoácidos neutros e hidrofóbicos diminuindo a afinidade do produto transcrito ao DNA, justificam esta degradação.

Segundo McLay e Clarke (2003), a protamina tem a capacidade de compactar 6 vezes mais o material genético do espermatozóide do que o DNA das células somáticas. Sendo assim, estas nucleoproteínas têm como função não só compactar, mas também estabilizar e proteger o material genético no núcleo do espermatozóide. Esta compactação da cromatina espermática diminui o volume da célula, o que facilita o trajeto pelo trato reprodutivo feminino. Esta alta compactação do DNA paterno pelas protaminas permite que, o espermatozóide passe pelas barreiras do trato reprodutivo feminino, penetre e ative o oócito, desencadeie o início do desenvolvimento embrionário, sem que haja danos de DNA, sendo possível expressar as informações genéticas de forma correta (OLIVA, 2006).

Durante o processo de protaminação, a cromatina espermática necessita da atividade das nucleases endógenas como a topoisomerase II. Esta enzima cliva o DNA espermático durante a espermiogênese para aliviar a tensão de torção da estrutura terciária da cromatina, o que facilita o processo de protaminação. Segundo Sakkas et al. (2002), estas clivagens são evidentes em estágios específicos da espermatogênese (espermátides redonda e alongada). Contudo, estas quebras de DNA são temporárias e devem ser reparadas pela própria célula, antes do fim do processo de protaminação (BALHORN, 1982; ANDRABI, 2007). Segundo Lewis e Agbaje (2008), células em estados avançados de diferenciação (espermatócitos, espermátides e espermatozóides) não tem mecanismo de reparo de DNA; sendo assim, mesmo sendo anormais ou que tenham iniciado o processo de apoptose, estas células podem não ser descartadas e estarem presentes no ejaculado. Isto pode explicar o aparecimento de espermatozóides defeituosos mesmo em animais férteis. 


\subsection{A FRAGMENTAÇÃO DE DNA ESPERMÁTICO}

Muitos estudos relacionam a alteração na fertilidade do macho com anormalidades morfológicas do espermatozóide ou diferenças do padrão funcional espermático como a motilidade e a integridade de acrossomo (JANUSKAUKAS et al., 2000; BRITO et al., 2003; TARTAGLIONE; RITA, 2004). Já foi sugerido que a diferença na fertilidade entre indivíduos se deve a fatores intrínsecos do espermatozóide que não são selecionados pelo trato reprodutivo feminino. Estes espermatozóides, mesmo defeituosos podem penetrar o oócito, mas falham em iniciar a seqüência do desenvolvimento embrionário normal (EID; LORTON; PARRISH, 1994).

Apesar do oócito ser capaz de reparar danos no DNA espermático que ocorreram antes da fecundação, este reparo é limitado (FATEHI et al., 2006; DERIJCK et al., 2008) e, quanto maior for o dano no material genético do espermatozóide, menor a chance de gestação (VIRRO; LARSON-COOK; EVENSON, 2004). Adicionalmente, esta capacidade pode ser diferente entre oócitos do mesmo ou de diferentes indivíduos e depende do tipo e extensão do dano presente no DNA do espermatozóide (SAKKAS et al., 2010). Em um estudo realizado por Ahmadi e $\mathrm{Ng}$ (1999), verificou-se que o desenvolvimento embrionário e fetal em camundongos está relacionado ao grau de dano de DNA e que o oócito tem a capacidade de reparar o DNA espermático quando este dano é menor do que $8 \%$.

$\mathrm{Na}$ reprodução de bovinos, os animais utilizados em programas de inseminação artificial (IA) e de produção in vitro (PIV) de embriões são selecionados geneticamente e têm a fertilidade comprovada. Contudo, os resultados de PIV de embriões em bovinos variam entre touros e muitas vezes não correspondem à fertilidade a campo.

O sucesso da PIV de embriões está relacionado à capacidade de separar uma quantidade adequada de espermatozóides móveis e com acrossomo e DNA intactos. Muitos métodos têm sido desenvolvidos, sendo a técnica de centrifugação em gradiente de Percoll a mais utilizada para recuperar esta população de espermatozóides de uma amostra de sêmen congelado (RECKOVA et al., 2008). Segundo Parrish, Krogenaes e Susko- 
Parrish (1995), em comparação com outras técnicas de separação, este método consegue separar uma maior quantidade de espermatozóides móveis para a PIV de embriões. Entretanto, apesar desta população apresentar alta proporção de espermatozóides viáveis com acrossomo intacto, o DNA pode estar alterado, uma vez que os espermatozóides de alguns touros podem ser muito sensíveis a este processo (ALOMAR et al., 2006). Adicionalmente, já foi descrito que a centrifugação por si só pode aumentar as espécies reativas de oxigênio (EROs) que aumentam as chances de dano de DNA espermático (AITKEN; CLARKSON, 1988).

O sucesso da fecundação também depende da capacidade do espermatozóide sofrer reação acrossômica. Para estimular esta condição in vitro, os meios de cultivo são suplementados com agentes capacitores. Para a espécie bovina o mais comumente utilizado é a heparina que auxilia na remoção dos fatores decapacitantes presentes na membrana do espermatozóide (PEREIRA et al., 2000). Entretanto, mesmo dentro das condições padrão de capacitação espermática in vitro, a proporção de espermatozóides que sofrem a reação acrossômica pode ser muito variável, dependendo da raça do animal e das características individuais.

Em bovinos já foi sugerido que a redução dos índices de fecundação in vitro pode estar relacionada com alterações da integridade de DNA espermático que podem ocorrer durante o processo de separação do sêmen ou durante a reação acrossômica (BOE-HANSEN et al., 2003). Já foi descrito em humanos a ocorrência de fragmentação de DNA espermático em momentos específicos da vida do homem. Agarwal, Shyam e Allamaneni (2005) relataram que as causas de fragmentação de DNA em humanos podem ser condições transitórias e estar relacionadas com doenças, uso de drogas, febre alta, aumento da temperatura testicular, poluição do ar, cigarro e idade avançada. Extrapolando para a reprodução em bovinos, isso também poderia influenciar o sêmen dos animais, mesmo que estes sejam dotados de alto potencial genético, uma vez que estes touros também estão sujeitos a estresse térmico, insulação testicular, alteração de alimentação, doenças e idade avançada. Desta forma, diferentes partidas de sêmen poderiam apresentar diferença de potencial de fertilidade, ou seja, baixa fertilidade esporádica. De forma geral, os danos de fita simples de DNA tem melhor 
prognóstico e são mais fáceis de serem reparadas do que os danos de fita dupla (SAKKAS et al., 2010). Dentre as causas de dano de DNA mais importantes descritos na literatura destacam-se a apoptose, a deficiência de protamina e as EROs (BARROSO et al., 2009).

\subsubsection{Fragmentação de DNA espermático por apoptose na espermatogênese}

A apoptose é um tipo de morte celular programada que ocorre em condições fisiológicas como por exemplo durante o desenvolvimento embrionário normal; no entanto pode estar presente em condições patológicas, como no desenvolvimento tumoral ou na aquisição de resistência à quimioterápicos (KAUFMANN et al., 2001). Durante a apoptose, a célula apresenta condensação e fragmentação da cromatina nuclear, compactação das organelas citoplasmáticas, dilatação do retículo endoplasmático, diminuição do volume celular e alterações na membrana plasmática (RAFF, 1998). Muitas das alterações morfológicas apresentadas pelas células em apoptose são causadas por proteases específicas chamadas caspases. A ativação destas caspases pode ser resultado de diversos mecanismos de sinalização intra ou extracelular que levam à destruição de proteínas vitais e à morte celular (KAUFMANN et al., 2001).

Este processo de morte celular programada também está presente nos testículos. A apoptose nas células germinativas, que afeta principalmente as espermatogônias e espermatócitos, parece ser essencial para o funcionamento normal da espermatogênese durante a puberdade. $\mathrm{Na}$ espermatogênese de indivíduos adultos também ocorre episódios de apoptose. Segundo Sakkas et al. (1999), aproximadamente 50 a 60\% das células germinativas que entram em divisão (meiose I) sofrem apoptose e são fagocitadas e eliminadas pelas células de Sertoli.

Estudos conduzidos em camundongos mostraram que fatores pró e anti-apoptóticos são responsáveis por manter a homeostase das células germinativas masculinas (RODRIGUEZ et al., 1997; RUSSEL et al., 2002). 
Segundo estes autores, as células de Sertoli podem iniciar e regular a apoptose das células germinativas conduzida pelo sistema Fas, que é caracterizado pela interação entre a proteína Fas e seu ligante. A cascata de eventos envolvidas na apoptose também inclui a ativação de endonucleases que induzem a quebra da cromatina.

A razão porque a morte celular programada da grande parte das espermatogônias acontece durante a espermatogênese normal, ainda não é totalmente conhecida. Contudo, sabe-se que as células de Sertoli disponíveis só podem sustentar e promover um ambiente favorável, com uma quantidade limitada de células germinativas. Desta forma, a apoptose ocorre para eliminar o excesso de células germinativas as quais as células de Sertoli não podem abrigar. Por outro lado, a apoptose pode acontecer também para eliminar algumas células germinativas que não foram detectadas por alguns pontos críticos de checagem, como por exemplo, durante as divisões mitóticas e meióticas. A apoptose nestes pontos de checagem auxilia não só a eliminar o número de células germinativas em relação às células de Sertoli, como também a controlar problemas como danos irreversíveis de DNA (BAUM; St. GEORGE; McCALL, 2005; MAKKER; AGARWAL; SHARMA, 2009).

Em indivíduos com sêmen normal, a apoptose é detectada em uma pequena porcentagem de espermatozóides no ejaculado. Entretanto, a apoptose nos testículos também pode apresentar falhas, o que contribui para a má qualidade do sêmen. Neste caso, ocorre o processo conhecido como apoptose abortiva, no qual algumas células escapam das etapas finais do processo de morte celular e aumentam a população de células anormais no ejaculado (YIN et al.,1998, SHAMSI; KUMAR; DADA, 2008).

A presença de espermatozóides apoptótico pode ser resultado de diversos tipos de injúrias. Segundo Nanassy e Carrel (2008), indivíduos mais velhos podem apresentar fragmentação de DNA em decorrência da diminuição da atividade apoptótica na espermatogênese. Em 2009, Barroso et al. observaram que a apoptose pode ser iniciada in vivo, no testículo (deficiência hormonal, irradiação, agentes tóxicos, químicos ou térmicos), no epidídimo (sinalização feita por espermatozóides anormais, senis ou por leucócitos) ou no sêmen (EROs ou ausência de antioxidantes) podendo também ser causada por fatores presentes no trato reprodutivo feminino. 
Um trabalho publicado por Sakkas et al. (1999) verificou que indivíduos oligozoospérmicos apresentavam níveis mais elevados de expressão de Fas (um dos receptores de morte celular) nos espermatozóides ejaculados, quando comparado com indivíduos férteis. Os resultados deste estudo sugerem que a apoptose é um mecanismo de controle da espermatogênese; entretanto este aumento de células marcadas com fas no ejaculado de indivíduos oligozoospérmicos pode ser indicativo de falha neste mecanismo de controle (apoptose abortiva). Em concordância a este relato, Francavilla et al. (2000) acrescentam que indivíduos com espermatogênese reduzida podem não produzir espermatozóides suficientes para desencadear o processo de apoptose o que pode acarretar no aumento de células marcadas para apoptose no ejaculado.

Algumas evidências observadas sugerem que a apoptose abortiva pode ocorrer em indivíduos com parâmetros seminais anormais com alta concentração de marcadores seminais de apoptose, como Fas e p53 nos espermatozóides ejaculados (SAKKAS et al., 1999). Desta forma, a apoptose abortiva pode ser uma das causas de dano de DNA. Uma vez presentes no sêmen, estas células marcadas para apoptose que não foram eliminadas, podem apresentar alterações típicas como o dano de cromatina (TAROZZI et al., 2007). Como uma das características destas células em apoptose é a fragmentação de DNA, isso pode alterar a capacidade fecundante destas células ou em etapas mais tardias, alterações no desenvolvimento embrionário, casos de abortamento ou fetos com defeitos congênitos (SINGH et al., 2003; HENKEL et al., 2004; SACKKAS et al., 2010).

\subsubsection{A fragmentação de DNA espermático por deficiência de protamina}

A protamina é a proteína responsável por preservar a integridade do material genético do espermatozóide. O alto poder de compactação promovido por esta nucleoproteína faz com que a cromatina do espermatozóide fique inerte e protegida até o momento da fecundação. Em situações de deficiência 
de protaminas, o DNA espermático pode apresentar pontos susceptíveis à fragmentação por falta de compactação da cromatina.

A importância de detectar populações de espermatozóides com defeitos de protaminação foi descrita por Bizarro et al. (1998). Neste estudo, os autores observaram que espermatozóides com deficiência de protamina poderiam apresentar maior susceptibilidade de apresentar danos de DNA por estresse químico e radiação.

Segundo Erenpreiss et al. (2006), a utilização de espermatozóides com dano de DNA na PIV de embriões humanos aumenta a chance de perda embrionária. Os pesquisadores relataram ainda que embriões produzidos por espermatozóide com fragmentação de DNA podem bloquear em qualquer fase do desenvolvimento embrionário. Caso não ocorra este bloqueio, os fetos poderão chegar a termo, contudo, os bebês poderão nascer apresentando anormalidades. Em outro trabalho, Nasr-Esfahani et al. (2004) observaram que as falhas de fecundação estavam mais relacionadas a problemas no espermatozóide $(59,09 \%)$, do que a alterações intrínsecas no oócito (27,30\%).

Desde o fim da década de 80 , já existem relatos de que a protamina exerce grande influência na fertilidade humana (BALHORN et al., 1982). Atualmente, a quantidade de informações sobre estas nucleoproteínas é vasta. Em humanos, já foi descrito que não é apenas o aumento (ou a diminuição) da P1 ou da P2 que pode acarretar em dano no DNA do espermatozóide. Segundo Aoki et al. (2005), a relação P1/P2 também é importante para predizer a fertilidade, sendo a razão 1:1 a ideal. Segundo Oliva (2006) estas alterações da razão P1/P2 pode ser conseqüência de falha generalizada na substituição das histonas por protaminas durante a espermiogênese.

Em concordância, McPherson et al. (1992) descreveram a importância da quebra do DNA pela topoisomerase II durante a troca das histonas pelas protaminas. Conseqüentemente, a presença destas quebras de DNA em espermatozóides ejaculados pode ser indicativa de maturação espermática incompleta durante a espermiogênese, o que acarreta em alteração da condensação da cromatina devido à falha de protaminação.

Em camundongos, também foi observado que o desequilíbrio da razão P1/P2 altera a integridade do DNA e o subseqüente desenvolvimento embrionário (SUGANUMA et al., 2005). Em bovinos, pouco se sabe sobre o 
papel e a importância da P1 e da P2. Por haver degradação da P2 no final da espermatogênese, a razão P1/P2 poderá ser importante somente durante as fases iniciais do processo, necessitando de maiores estudos para saber a influência destas proteínas e o efeito de uma possível alteração das mesmas na fertilidade dos touros.

\subsubsection{A fragmentação de DNA espermático por espécies reativas de oxigênio (EROs)}

As EROs são moléculas ou átomos que contém elétrons despareados na órbita mais externa. Isto torna estas substâncias extremamente instáveis, conferindo-Ihes uma reatividade química de interação com outras moléculas. Os principais metabólitos de oxigênio produzidos pela redução de um dos elétrons são: radical superóxido $\left(\mathrm{O}_{2}^{-}\right)$, radical hidroxila $\left(\mathrm{OH}^{-}\right)$e peróxido de hidrogênio $\left(\mathrm{H}_{2} \mathrm{O}_{2}\right)$. As EROs são capazes de reagir com qualquer molécula com quem tenham contato, extraindo elétrons e gerando novos radicais livres citotóxicos (URREGO et al., 2008).

As EROs são componentes normais da fisiologia celular. Em espermatozóides, as EROs também desempenham funções importantes durante a espermatogênese, pois participam dos processos de capacitação, de reação acrossômica, de hiperativação e de ligação do espermatozóide com a zona pelúcida do oócito (BLUMER et al., 2008). Apesar deste efeito benéfico na fisiologia do espermatozóide, o desequilíbrio entre a produção e a eliminação das EROs no sêmen pode ser prejudicial ao espermatozóide. Isso pode ocorrer por excesso de produção de EROs ou pela diminuição dos agentes antioxidantes.

Os antioxidantes são substâncias que tem a capacidade de retardar ou prevenir significativamente a reação de oxidação. Estas substâncias estão presentes tanto no espermatozóide como no plasma seminal. Para proteger os espermatozóides contra a produção excessiva de EROs, o plasma seminal possui uma série de antioxidantes enzimáticos (por exemplo, superóxido desmutase, sistema glutationa peroxidase / glutationa redutase e catalase) e 
não enzimáticos (por exemplo, ascorbato, urato, a-tocoferol, piruvato, glutationa, taurina e hipotaurina). Contudo, a capacidade de proteção do espermatozóide, por si só é muito pequena, sendo então dependente dos antioxidantes presentes no plasma seminal. Os antioxidantes, como por exemplo, a-tocoferol, têm a capacidade de quebrar a cadeia de formação das EROs, resultando na formação de produtos sem elétrons despareados (NICHI, 2009).

O espermatozóide é altamente susceptível aos danos causados pelas EROs devido à grande quantidade de ácidos graxos poliinsaturados (polyunsaturated fatty acids - PUFA) presentes na membrana plasmática e baixas concentrações de enzimas antioxidantes em seu reduzido citoplasma (NICHI, 2009). Os PUFAs são considerados essenciais aos mamíferos, uma vez que estes não são capazes de sintetizá-los; além disso, contribuem para a fluidez de membrana, o que é importante para o movimento dos espermatozóides e necessário para os eventos de fusão de membranas durante o processo de fecundação (BLUMER et al., 2008). As insaturações presentes na membrana do espermatozóide garantem uma maior resistência à criopreservação além de favorecer a motilidade destas células. Entretanto, as EROs atacam preferencialmente as ligações carbono-hidrogênio adjacentes às dupla-ligações presentes nos PUFAS e iniciam uma cascata de peroxidação lipídica, que se não for interrompida, pode afetar a integridade da cromatina espermática e aumentar a freqüência de quebras no DNA (AITKEN et al., 2001).

Existem pelo menos duas fontes principais de EROs no sêmen, o próprio espermatozóide e os leucócitos. Os espermatozóides possuem grande quantidade de mitocôndrias que são as principais fontes de EROs (ALLAMANENI et al., 2005). Segundo Makker; Agarwal; Sharma (2009), a geração de EROs pelo espermatozóides pode ocorrer via sistema nicotinamida adenina dinucleotideo fosfato oxidase (NADPH) presente na membrana ou pela oxiredutase NADPH-dependente presente na membrana mitocondrial, que são fontes de elétrons para a produção de EROs. Espermatozóides anormais ou imóveis são exemplos de células produtoras de EROs. Os mecanismos responsáveis pela geração de EROs mitocondrial ainda não são totalmente conhecidas; entretanto, uma hipótese é que as mitocôndrias 
perdem elétrons sendo responsáveis por uma parte das EROs produzidas pelos espermatozóides (ANDRABI, 2007). Os leucócitos, em humanos são considerados a maior fonte produtora de EROs no plasma seminal e quando ativados, estas células tem a capacidade de produzir até 1000 vezes mais EROs do que os espermatozóides (PASQUALOTTO et al., 2003). Entretanto, a ação deletéria das EROS produzida por leucócitos, só acontece na ausência dos antioxidantes (WOLFF, 1995).

Na membrana plasmática dos espermatozóides, o radical hidroxila inicia a oxidação dos ácidos graxos poli-insaturados em um processo conhecido como peroxidação lipídica. Devido ao fato de cada ácido graxo que participa da peroxidação lipídica ser capaz de gerar um radical com o potencial para produzir a peroxidação de outro ácido graxo, este fenômeno é considerado altamente deletério e acarreta na diminuição da fluidez de membrana e na redução da capacidade fecundante do espermatozóide (MAKKER; AGARWAL; SHARMA, 2009).

A integridade do DNA espermático também pode ser afetada pela alta concentração de EROs. Segundo Urrego et al. (2008), o radical $\mathrm{OH}^{-}$ desempenha um papel determinante nos danos à cromatina espermática, podendo alterar a estrutura das purinas e pirimidinas nas cadeias de ácidos nucléicos (DNA e RNA) além de gerar quebras na cadeia de polinucleotídeos, alterando assim, a informação genética. Entretanto, vale ressaltar que os danos de cromatina são os últimos a acontecer em decorrência do aumento das EROs. Segundo Barros (2007), estas moléculas podem causar, por exemplo, alterações de membrana e de organelas como as mitocôndrias que também podem influenciar o processo de fecundação e até mesmo o desenvolvimento embrionário.

De acordo com Erenpreiss et al. (2006), as EROs modulam a atividade de genes e proteínas vitais para a proliferação, a diferenciação e a função dos espermatozóides. A quantidade de EROs produzida no sêmen de um indivíduo fértil é controlada pelos antioxidantes seminais. Segundo Aitken et al. (1992), na presença de espermatozóides morfologicamente anormais e leucócitos no sêmen a quantidade de EROs produzida ultrapassa a produção de antioxidantes e, normalmente, o sêmen com estas características apresenta 
diminuição dos índices de embriões PIV de embriões associado a danos de DNA.

Diante deste cenário fica evidente que para a espécie humana, a avaliação da apoptose espermática, a deficiência de protamina e do estresse oxidativo no sêmen ejaculado é de extrema importância para minimizar as consequências da fragmentação de DNA espermático no desenvolvimento embrionário. Porém, em reprodução humana assistida, as análises são feitas normalmente em sêmen fresco, ao contrário da reprodução na espécie bovina que utiliza sêmen congelado para a maioria das biotecnologias. Neste sentido, pode ser que algumas avaliações como a apoptose espermática e a deficiência de protamina, não tenham a mesma importância para a espécie bovina quando comparado à humanos. Simões et al. (2009) objetivando esclarecer a protaminação na espécie bovina, validaram um teste rápido e fácil para a espécie. Os autores verificaram que a incidência da deficiência de protaminas na espécie bovina é baixa, ou seja, não parece ser um fator determinante para a fragmentação de DNA na espécie.

No que diz respeito a apoptose espermática, a criopreservação do sêmen não altera o número de células positivas já que esta injúria ocorre durante a espermatogênese, ou seja, uma causa de fragmentação de DNA testicular. Entretanto, a criopreservação pode causar efeitos deletérios aos espermatozóides durante o processo de industrialização do sêmen (TARTAGLIONE; RITTA, 2004). Sendo assim, o processo de criopreservação de sêmen pode como consequência causar estresse oxidativo no espermatozóide criopreservado, e portanto levar à fragmentação de DNA.

\subsection{A FRAGMENTAÇÃO DO DNA ESPERMÁTICO E O DESENVOLVIMENTO EMBRIONÁRIO INICIAL}

Tesarik, Greco e Mendonza (2004) relataram que a influência paterna pode acontecer precoce ou tardiamente no desenvolvimento embrionário. $\mathrm{O}$ efeito do genoma paterno no início do desenvolvimento embrionário acontece antes da ativação do genoma embrionário e parece ser mediado por fatores de 
ativação oocitários. Eid, Lorton e Parrish (1994) e Comizzoli et al. (2000) demonstraram que em bovinos, o sêmen pode afetar o momento do início e a duração da replicação do DNA durante o primeiro ciclo celular e consequentemente afetar o início da primeira clivagem. Por outro lado, a ausência do efeito paterno no índice de fecundação e no desenvolvimento embrionário inicial pode estar relacionada à alteração do genoma materno (SELI et al., 2004).

Fatores espermáticos são responsáveis pelas primeiras divisões embrionárias. Estudos demonstram que existe influência paterna direta com relação ao índice de blastocisto produzido (COMIZZOLI et al., 2000; WARD et al., 2001; TAMASSIA et al., 2003). Em um estudo realizado em 2006, Fatehi et al. induziram dano de DNA em espermatozóides bovinos e após a PIV de embriões, os autores observaram que as células com alteração de DNA não perderam a capacidade de fecundar o oócito, porém relatam que o bloqueio do desenvolvimento embrionário ocorreu após a $2^{\mathrm{a}}-3^{\mathrm{a}}$ clivagem. Os autores observaram ainda anormalidades na formação do fuso meiótico e na fragmentação de DNA espermático, o que resultou neste bloqueio embrionário.

O desenvolvimento embrionário em mamíferos é dependente de fatores genéticos e não genéticos oriundos dos pais. O espermatozóide pode afetar o desenvolvimento embrionário se o tempo de fecundação ou as primeiras clivagens forem atrasados. Por exemplo, embriões produzidos por touros de alta fertilidade entram na fase $S$ do primeiro ciclo celular mais rápido e tem maior duração do que os embriões produzidos por touros de baixa fertilidade (EID et al., 1994). Segundo estes autores, este atraso ocorre na tentativa da célula em reparar o dano de DNA espermático.

Danos no espermatozóide podem ocorrer ainda no trato reprodutivo masculino ou após a deposição destes no trato reprodutivo feminino. Em bovinos, o estresse térmico escrotal leva à produção de espermatozóides que produzem embriões com formação atrasada ou reduzida de pró-núcleos, embriões com baixa capacidade de atingir o estádio de blastocisto e em alguns casos, leva a apoptose embrionária (HENDRICKS et al., 2009).

A apoptose em células embrionárias tem sido amplamente estudada por causa do potencial destas células em responder às condições sub-ótimas de desenvolvimento e estresse (BETTS et al., 2001). Segundo Fabian et al. 
(2005), a apoptose embrionária não é observada durante o desenvolvimento normal de embriões antes da ativação do genoma embrionário, que ocorre entre 8 - 16 células na espécie bovina sendo que os maiores índices de apoptose espontânea ocorrem no estádio de blastocisto (GOJORRET et al., 2003).

Uma função importante do processo apoptótico durante o desenvolvimento embrionário é a eliminação e o controle das células anormais e excedentes. A consequência deste processo possui relação direta com a extensão (número de células afetadas) da morte celular. Um aumento massivo na proporção dos blastômeros que entram em apoptose é prejudicial para o desenvolvimento embrionário (BRAD et al., 2007).

Trabalhos demonstram que a análise do DNA do espermatozóide é importante para a realização da fecundação in vitro (FIV) ou da injeção intracitoplasmática de espermatozóide (ICSI) (ESTERHUIZEN et al., 2000; FERNANDEZ et al., 2003; ENCISO et al., 2006). Segundo Virro, Larson-Cook e Evenson (2004), as anormalidades do genoma paterno podem afetar o desenvolvimento embrionário, mesmo quando o espermatozóide é diretamente injetado no oócito pela ICSI. Segundo Tesarik, Greco e Mendonza (2004), as falhas na reprodução assistida humana sem causa aparente podem estar relacionadas à fragmentação do DNA espermático. Em concordância, Esterhuizen et al. (2000) observaram que espermatozóides morfologicamente normais podem conter cromossomos com microdeleções, aneuploidias, fragmentação de DNA e estrutura de cromatina anormal, contudo não perdem a capacidade de fecundar o oócito.

Algumas particularidades do espermatozóide podem explicar a presença de alterações de cromatina em células morfologicamente normais. Segundo Fatehi et al. (2006), as células espermáticas não tem expressão gênica, uma vez que a transcrição de DNA está completamente silenciada. Os espermatozóides além de conter baixa quantidade de RNA, também não possuem ribossomos e retículo endoplasmático, maquinarias necessárias para a tradução do RNA. Sendo assim, a síntese protéica é inexistente na célula espermática matura.

$\mathrm{Na}$ reprodução humana, a detecção de danos no DNA de espermatozóides é de grande valia para se obter melhores índices de 
gestação. Já na espécie bovina, muito foi estudado quanto à análise da viabilidade do sêmen criopreservado. Ao se conseguir bons índices de prenhez, a evolução da pesquisa nesta área sofreu uma desaceleração. Desde então, poucos avanços foram feitos quanto ao conhecimento molecular e funcional da célula espermática. Neste sentido, independente da causa que originou o dano de DNA espermático é importante ampliar o conhecimento do real efeito da fragmentação de DNA no desenvolvimento embrionário, a causa e a conseqüência deste dano, os mecanismos regulatórios, que se ausentes fazem com que as células fiquem mais susceptíveis aos danos, quais são os fatores envolvidos no processo de fragmentação, entre outros.

Diante destas informações, talvez seja possível desenvolver novas estratégias para identificar os animais com alto nível de fragmentação de DNA espermático e assim decidir qual o melhor método a ser utilizado e qual o efeito desta fragmentação para os índices reprodutivos do rebanho. 


\section{HIPÓTESE}

A fragmentação de DNA espermático compromete o desenvolvimento embrionário, pois desencadeia a apoptose nas células embrionárias. 
Objetivos 


\section{OBJETIVOS}

\section{Geral}

Verificar a influência do genoma paterno no desenvolvimento embrionário in vitro.

\section{Específicos}

1) Avaliar o índice de fragmentação de DNA espermático em uma população de touros.

2) Correlacionar a fragmentação de DNA espermático com a susceptibilidade ao extresse oxidativo.

3) Avaliar a influência da fragmentação de DNA espermático na qualidade dos embriões produzidos in vitro. 
Material e Método 


\section{MATERIAL E MÉTODO}

O presente estudo foi conduzido nas instalações dos Laboratórios de Fecundação in vitro, Clonagem e Transgenia Animal e no Laboratório de Andrologia, ambos do Departamento de Reprodução Animal da Faculdade de Medicina Veterinária e Zootecnia da Universidade de São Paulo.

\subsection{EXPERIMENTO 1: AVALIAÇÃO DO ÍNDICE DE FRAGMETNAÇÃO DE DNA ESPERMÁTICO DE UMA DETERMINADA POPULAÇÃO DE TOUROS}

Para responder ao objetivo proposto, ou seja, determinar um índice de fragmentação de DNA em uma população de touros, amostras de sêmen de distintos Centros de Coleta e Processamento foram analisadas pelo ensaio SCSA e depois agrupadas em grupos segundo incidência de DNA fragmentado na amostra.

\subsubsection{Avaliação da susceptibilidade da fragmentação de DNA espermático pelo Ensaio de Estrutura de Cromatina Espermática - SCSA para a divisão dos grupos experimentais}

Para verificar a susceptibilidade de fragmentação de DNA espermático na espécie bovina, o ensaio SCSA foi empregado em uma determinada população de touros. Amostras congeladas de sêmen de 221 touros oriundos de diferentes Centros de Coleta e Processamento de Sêmen (CCPs) foram submetidas ao ensaio de SCSA. O teste de SCSA foi padronizado com sêmen de um touro escolhido de maneira aleatória (Apêndice A). 
As palhetas de sêmen foram descongeladas em água a $37^{\circ} \mathrm{C}$ por 30 segundos, sendo então o conteúdo depositado no fundo de um tubo cônico de $15 \mathrm{ml}$ e deixado em gelo até a realização da análise. Alíquotas de sêmen foram diluídas para um volume total de 200 ul com tampão TNE (ANEXO D) e concentração de $2 \times 10^{6}$ células $/ \mathrm{ml}$. Imediatamente depois, $0,40 \mathrm{ml}$ de solução detergente ácida (ANEXO D) foram adicionados. Após 30 segundos, adicionouse $0,6 \mathrm{ml}$ de solução de laranja de acridina (LA) contendo $6 \mathrm{ug} \mathrm{LA} / \mathrm{ml}$ de tampão (Sigma, St. Louis, MO, E.U.A - ANEXO D). As amostras foram analisadas utilizando 0 citômetro de fluxo Guava EasyCyte ${ }^{\circledR}$ (Guava Technologies, Hayward, CA, E.U.A), com exitação de 488 nm e 15 mW.

Após a análise dos índices de fragmentação de DNA de cada touro, os mesmos foram então divididos em seis grupos formando blocos completamente aleatórios, a saber: Grupo 1 (0 a 0,99\% de fragmentação de DNA espermático, $\mathrm{n}=24)$, Grupo 2 (1 a 1,99\%, n = 78), Grupo 3 (2 a 2,99\%, n = 59), Grupo 4 (3 a 4,99\%, n = 34), Grupo 5 (5 a 5,99\%, n = 13) e Grupo 6 (6 a 12\%, n = 13). Sete animais de cada grupo foram escolhidos aleatoriamente para as avaliações espermáticas.

\subsubsection{Análise Estatística}

$\mathrm{Na}$ comparação entre a frequência de indivíduos de cada grupo experimental de acordo com o índice de fragmentação de DNA dentro da população estudada foi utilizado o teste Qui-quadrado com nível de significância de 5\%. Para as comparações dois a dois foi empregada a correção de Yates. 


\subsection{EXPERIMENTO 2: INFLUÊNCIA PATERNA NA PRODUÇÃO IN VITRO DE EMBRIÕES}

Para verificar a influência paterna na produção in vitro de embriões bovinos, sete animais de cada grupo experimental formado no experimento 1 foram submetidos às avaliações seminais descritas a seguir e posteriormente à produção in vitro de embriões.

\subsubsection{Avaliações espermáticas}

Uma palheta de sêmen de cada animal de cada grupo experimental foi descongelada em água a $37^{\circ} \mathrm{C}$ por 30 segundos e submetida a duas lavagens em PBS a $200 \mathrm{~g}$ por 5 minutos cada. Do sedimento da segunda lavagem foram retirados $5 \mu \mathrm{l}$ de sêmen para avaliação da motilidade em $245 \mu \mathrm{l}$ de meio de fecundação (ANEXO B) e outros $5 \mu$ l de sêmen para avaliação da concentração espermática em $245 \mu \mathrm{l}$ de água. A concentração espermática foi ajustada para que todas as amostras apresentassem $1 \times 10^{6}$ espermatozóides $/ \mathrm{mL}$, sendo então o sêmen destinado às distintas avaliações espermáticas: motilidade espermática, ensaio de SCSA (item 5.1.1), ensaio Cometa Alcalino (ítem 5.2.1.1) e ensaio TBARS (ítem 5.2.1.2).

\subsubsection{Ensaio Cometa Alcalino}

O protocolo utilizado foi adaptado de Donnelly et al. (2000). O ensaio Cometa foi realizado em condições alcalinas $(\mathrm{pH}>13)$. Lâminas histológicas foram previamente tratadas com Poli-L-Lisina (ANEXO F) por 15 minutos e secas em temperatura ambiente. Posteriormente, todas as lâminas foram cobertas com uma fina camada de agarose normal melting 1\% (ANEXO F) e 
secas em temperatura ambiente. As lâminas de cada animal foram feitas em duplicata.

Em cada lâmina foram adicionados $100 \mu \mathrm{l}$ de amostra de sêmen diluído $\left(0,5 \times 10^{6}\right.$ espermatozóides $/ \mathrm{mL}$ ) em agarose low melting (ANEXO F) e cobertas por lamínula $24 \times 50 \mathrm{~mm}$. Após o endurecimento da agarose, cerca de 10 minutos a $4^{\circ} \mathrm{C}$, a lamínula foi gentilmente retirada, sendo adicionados $300 \mu \mathrm{l}$ de agarose low melting. As lâminas foram novamente cobertas por lamínula $24 \times 50 \mathrm{~mm}$. Após o endurecimento da agaroses (10 minutos a $\left.4^{\circ} \mathrm{C}\right)$, a lamínula foi gentilmente retirada passando para a etapa de lise.

As lâminas foram cobertas com $1 \mathrm{ml}$ de solução de lise I (ANEXO F) e mantidas a $55^{\circ} \mathrm{C}$ por 1 hora em câmara úmida. Ao término, as lâminas foram lavadas 3 vezes com água Milli $Q$, para remover o excesso da solução de lise I. Após as lavagens, as lâminas foram cobertas com $1 \mathrm{ml}$ de solução de lise II (ANEXO F) e mantidas a $4^{\circ} \mathrm{C}$ por 2 horas.

Após a etapa de lise, as lâminas foram novamente lavadas 3 vezes com água Milli $Q$, para remover o excesso de sais e foram imersas na solução de eletroforese por 20 minutos. A eletroforese foi realizada durante 25 minutos a $3 \mathrm{~V} / \mathrm{cm}$ e amperagem ajustada para $270 \mathrm{~mA}$. Ao término, as lâminas foram lavadas 3 vezes com TBE 1X e submetidas à desidratação. Para esta etapa, as lâminas foram cobertas com etanol $70 \%, 92 \%$ e 100\% por 5 minutos em cada solução e secas em temperatura ambiente.

Depois de secas, as lâminas foram coradas com brometo de etídeo

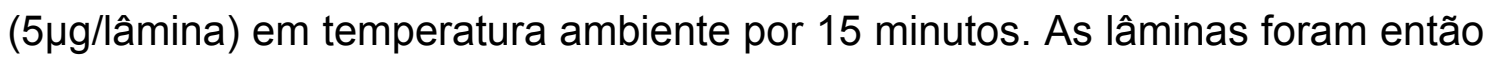
lavadas 3 vezes com TBE $1 \mathrm{X}$, secas com papel absorvente e cobertas com lamínula $24 \times 50 \mathrm{~mm}$. As imagens foram visualizadas em microscópio de epifluorescência Olympus IX80 (Tóquio, Japão) com filtro de excitação de 515$560 \mathrm{~nm}$ e filtro de barreira de $600 \mathrm{~nm}$, equipado com uma câmera OLYMPUS Q-Color5 $5^{\mathrm{TM}}$ de 5 megapixels, em aumento de 200x. As imagens de 100 Cometas de cada animal foram selecionados aleatoriamente e analisadas utilizando um software de imagens (Comet Score ${ }^{T M}$ ) proporcionado gratuitamente na internet pela empresa TriTek-Corp (http://autocomet.com/products_cometscore.php). 
O programa fornece um quadro de mensuração retangular para a avaliação dos Cometas. As células foram avaliadas quanto às variáveis: comprimento do Cometa (número de pixels na direção horizontal do Cometa), área do Cometa (número de pixels no Cometa), intensidade média do Cometa (intensidade média de pixels no Cometa), Olive Moment (soma dos valores dos perfis de intensidade de pixels na cauda, multiplicado pelas distâncias relativas com o centro da cabeça, dividido pela intensidade de pixels total do Cometa), intensidade média da cabeça do Cometa (intensidade média de pixels na cabeça do Cometa), porcentagem de DNA na cabeça (intensidade total de pixels na cabeça, dividido pela intensidade total do Cometa, multiplicado por 100 ), comprimento da cauda do Cometa (perfil resultante da subtração do perfil da cabeça pelo perfil do Cometa), intensidade média da cauda (intensidade média de pixels na cauda do Cometa), porcentagem de DNA na cauda do Cometa (intensidade total da cauda dividido pela intensidade total do Cometa, multiplicado por 100), tail moment (porcentagem de DNA na cauda multiplicada pelo comprimento do Cometa). Nesta técnica, as células adquirem uma morfologia semelhante a um Cometa, na qual a cabeça do Cometa representa o envoltório de DNA intacto e a cauda, os fragmentos de DNA (Figura 1). 

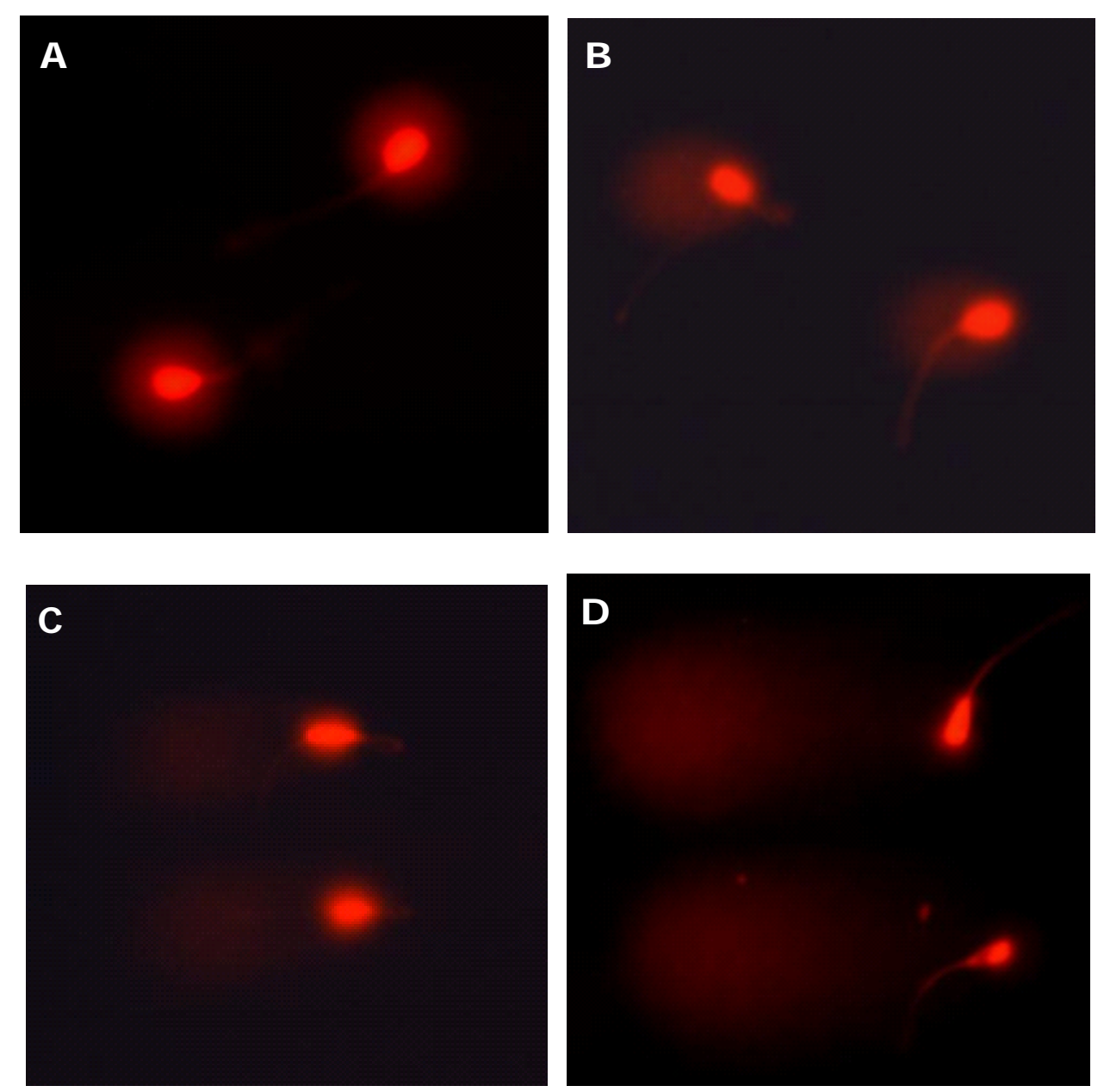

Figura 1 - Imagens ilustrativas da avaliação da fragmentação de DNA espermático pelo Ensaio Cometa Alcalino. (A) células com halo ao redor do núcleo corado, porém sem cauda de Cometa evidente, indicando pouca fragmentação; (B) células com pequena formação de cauda de Cometa, indicando danos leves de DNA espermático; (C) células com cauda de Cometa bem evidente, porém ainda com núcleo corado, indicando dano moderado de DNA espermático; (D) células com cauda de Cometa bem evidente, porém com núcleo fracamente corado, indicando intensa fragmentação de DNA espermático. 


\subsubsection{Ensaio de substâncias reativas ao ácido tiobarbitúrico - TBARS}

Após a fecundação in vitro, a concentração do sêmen de cada animal foi ajustada para $2,5 \times 10^{6}$ espermatozóides $/ \mathrm{ml}$. Ao sêmen diluído $(400 \mu \mathrm{l})$ de cada animal foram adicionados $100 \mu \mathrm{l}$ de sulfato ferroso $(4 \mathrm{mM})$ e $100 \mu \mathrm{l}$ de ascorbato de sódio (20 mM) (ANEXO G), sendo os tubos mantidos abertos e incubados a $37^{\circ} \mathrm{C}$ por 90 minutos. Após a incubação foi adicionado a cada amostra, ácido tricloroacético gelado a 10\% (TCA 10\%) na proporção de 1:2 (ANEXO G). As amostras foram centrifugadas a $18.000 \mathrm{~g}$ por 10 minutos para precipitar as proteínas e recuperar o sobrenadante. Todas as amostras foram congeladas $\left(-20^{\circ} \mathrm{C}\right)$ para posterior leitura.

No dia da leitura, uma alíquota de $500 \mu \mathrm{l}$ de TBA 1\%, dissolvido em hidróxido de sódio $(\mathrm{NaOH})$ a 0,05N (ANEXO G) foi acrescida a $500 \mu \mathrm{l}$ do sobrenadante anteriormente congelado. A mistura foi submetida à água fervente $\left(100^{\circ} \mathrm{C}\right)$ por 15 minutos e posteriormente resfriada em gelo $\left(0^{\circ} \mathrm{C}\right)$ para interromper a reação. O produto a ser mensurado da peroxidação lipídica é o malodialdeído (MDA). A mensuração do MDA ocorre em condições de alta temperatura e baixo $\mathrm{pH}(\mathrm{pH}<3)$, resultando em uma solução de coloração rosa que é então quantificada por espectofotometria. A mensuração do MDA foi realizada no Laboratório de Andrologia do Departamento de Reprodução Animal da FMVZ-USP por espectrofotometria com comprimento de onda de $532 \mathrm{~nm}$ e os resultados comparados à uma curva padrão feita com MDA previamente estabelecida no laboratório. A concentração dos TBARS foi determinada empregando como coeficiente de extinção molar do MDA o valor $1,56 \times 10^{5} \mathrm{X} \mathrm{M}^{-1} \mathrm{~mL}^{-1}$ (BUEGE; AUST, 1978). A peroxidação lipídica no sêmen foi expressa em nanogramas de TBARS $/ 10^{6}$ espermatozóides. 


\subsubsection{Produção in vitro de embriões}

Foram realizadas sete sessões de PIV de embriões. Em cada uma delas, obrigatoriamente foi utilizado sêmen de um animal de cada um dos grupos experimentais (descritos no ítem 5.1.1). Foi utilizado ainda sêmen de um animal, com índice de produção de embriões conhecido no laboratório, onde o experimento foi realizado, passando a ser o controle de qualidade das manipulações. Desta forma, quando os índices de desenvolvimento embrionário deste animal controle apresentaram resultados abaixo do esperado, todo material foi descartado para evitar erros nas avaliações dos grupos experimentais.

\subsubsection{Obtenção e maturação in vitro (MIV) dos oócitos}

Ovários de vacas destinadas ao abate comercial foram colhidos em matadouro localizado em Piracicaba - SP e transportados em recipiente térmico contendo solução fisiológica estéril aquecida a $30^{\circ} \mathrm{C}$. No laboratório, 2 a 3 horas após o abate, os ovários foram lavados duas vezes em solução fisiológica aquecida a $30^{\circ} \mathrm{C}$, sendo em seguida, aspirados os folículos com diâmetro entre 2 e $8 \mathrm{~mm}$ com agulha de calibre 21G acoplada à seringa de $5 \mathrm{ml}$. O líquido folicular aspirado foi depositado em tubo cônico de $15 \mathrm{ml}$, permanecendo em repouso por 10 minutos para decantação dos oócitos. Após este período, o sedimento de cada tubo foi colocado em placa de petri ( $90 \mathrm{~mm}$ ) com meio de lavagem (ANEXO A) para recuperação dos oócitos.

Apenas oócitos apresentando camada de células do cumulus oophorus espessa e compacta e com citoplasma homogêneo foram selecionados para maturação in vitro (MIV). Após a seleção, os oócitos foram lavados três vezes no meio de lavagem e colocados para maturar em microgotas de $90 \mu \mathrm{l}$ de meio de maturação sob óleo mineral (ANEXO A). Os oócitos permaneceram por 22 24 horas em incubadora a $39^{\circ} \mathrm{C}, 5 \% \mathrm{CO}_{2}$ em ar e alta umidade. 
5.2.2.2 Fecundação in vitro (FIV) e culitivo embrionário (CIV)

Os espermatozóides de cada animal foram preparados conforme descrito no item 5.1.1 e a concentração espermática ajustada para $1 \times 10^{6}$ células $/ \mathrm{ml}$. Os oócitos maturados in vitro $\left(\begin{array}{lll}20 & \text { a } 30\end{array}\right)$ e os espermatozóides foram incubados em microgotas $(90 \mu \mathrm{l})$ com meio de fecundação cobertas com óleo mineral, permanecendo em incubadora a $39^{\circ} \mathrm{C}$, $5 \% \mathrm{CO}_{2}$ em ar e alta umidade por 18 horas. Após este procedimento, os presumíveis zigotos foram retirados do meio de fecundação e as células do cumulus oophorus removidas mecanicamente com auxílio de pipeta automática.

Os presumíveis zigotos foram co-cultivados (CIV) em monocamada de células da granulosa em meio SOFaa (ANEXO C), por 7 dias, até o estádio de blastocisto. Foram realizados dois acréscimos de meio de cultivo (feeding), sendo o primeiro, 48 horas após o início do co-cultivo (D2) e o outro no D5.

\subsubsection{Avaliação embrionária}

Os índices de clivagem e de blastocisto foram avaliados nos dias 2 e 7 de cultivo, respectivamente. Estes índices foram calculados em relação ao número total de estruturas de cada grupo. Para verificar a qualidade embrionária, no $\mathrm{D} 7$, os blastocistos produzidos por cada animal foram submetidos ao ensaio de TUNEL para avaliação da apoptose embrionária.

Os embriões foram submetidos ao ensaio de TUNEL utilizando o kit comercial In Situ Cell Death Detection Kit, Fluorescein (Boehringer Mannheim/Roche Diagnostics, USA) como descrito por Paula-Lopes et al. (2003), com pequenas modificações.

No D7, todos os embriões em estádio de blastocisto produzidos por cada um dos touros foram lavados 3 vezes em solução de PBS-PVP (ANEXO E) e fixados em paraformaldeído 4\% (ANEXO E) por 1 hora em temperatura 
ambiente. Posteriormente, os embriões foram lavados novamente em PBSPVP e mantidos em $400 \mu$ l desta solução em geladeira até o dia da leitura.

No dia da leitura, os embriões foram submetidos à solução de Permeabilização (ANEXO E) em câmara escura e úmida e temperatura ambiente por 2 horas e depois lavados 2 vezes em PBS-PVP. Os controles positivos para o ensaio de TUNEL e os embriões de cada grupo experimental foram lavados em PBS/PVP e incubados com $25 \mu \mathrm{L}$ de mistura de reação de TUNEL (contendo fluorescein isothiocyanate-conjugated dUTP e a enzima desoxinucleotidil transferase terminal preparados segundo instruções do fabricante) por 1 hora à $37^{\circ} \mathrm{C}$ em câmara úmida e escura. Os controles negativos para o ensaio de TUNEL foram incubados sem a enzima desoxinucleotidil transferase terminal por 1 hora à $37^{\circ} \mathrm{C}$ em câmara úmida e escura.

Depois de corados para a reação de TUNEL, os embriões foram lavados novamente em solução de PBS-PVP e corados com Hoechst $33342(5 \mu \mathrm{g} / \mathrm{ml})$ (Sigma St. Louis, MO, USA) (ANEXO E) por 10 minutos em temperatura ambiente. Os embriões foram então lavados 6 vezes em PBS-PVP e colocados entre lâmina e lamínula com 1,4 -Diazabicyclo [2.2.2]octane (DABCO - Sigma St. Louis, MO, USA; ANEXO E) para avaliação em microscópio de epifluorescência Olympus IX80 (Tóquio, Japão). Cada embrião foi analisado sendo o número total de células (núcleos azuis) e o número de células embrionárias em apoptose (núcleos verdes), visualizados pelos filtros DAPI e FITC, respectivamente.

\subsubsection{Análise Estatística}

Os dados obtidos nas avaliações espermáticas, PIV de embriões e avaliação embrionária foram analisados pelo programa SAS System for Windows (SAS, 2000). Utilizando o aplicativo Guided Data Analisys, os dados foram testados quanto à normalidade dos resíduos (distribuição normal) e homogeneidade das variâncias. Caso não obedecessem a estas premissas, os 
mesmos foram transformados (logaritmo na base 10 - $\log _{10} X$; Raiz quadrada $R Q$ X; Quadrado $-X^{2}$ ) e se a normalidade não fosse obtida, foi empregado então, o procedimento NPAR1WAY de análise de variância não paramétrica. Para os testes Pos Hoc foi utilizado o teste Least Significant Differences (LSD).

Para a descrição dos resultados foram empregadas as médias e seus respectivos erros padrões (média \pm erro padrão da média) dos dados originais e os níveis de significância (p).

O nível de significância utilizado para rejeitar $\mathrm{HO}$ (hipótese de nulidade) foi de $5 \%$, isto é, para um nível de significância menor que 0,05 foram considerados que ocorreram diferenças significativas entre os diferentes graus de fragmentação avaliados pelo SCSA para uma determinada variável resposta.

As correlações de Pearson e Spearman (PROC CORR) foram utilizadas para calcular a relação entre as variáveis paramétricas e não paramétricas, respectivamente, sendo os resultados expressos pelo coeficiente de correlação $(r)$ e respectivo nível de significância ( $p$ ).

As variáveis respostas área de Cometa, Olive moment, intensidade média da cauda do Cometa, porcentagem de DNA na cauda do Cometa, tail moment, TBARS e SCSA-FIV, não obedeceram às premissas, sendo as mesmas obtidas por transformação para o logarítmo na base 10 de seus valores.

As variáveis respostas número total de núcleos (NT), células positivas para reação de TUNEL, motilidade, índice de clivagem, intensidade média da cabeça do Cometa e porcentagem de DNA na cabeça do Cometa obedeceram às premissas não sendo necessárias quaisquer transformações.

A variável resposta comprimento do Cometa não obedeceu à normalidade dos resíduos, sendo a mesma obtida por transformação para o inverso de seus valores. As variáveis respostas índice de blastocisto e SCSA não obedeceram às premissas, sendo as mesmas transformadas para a Raiz Quadrada de seus valores. 


\subsection{DELINEAMENTO EXPERIMENTAL}

Este trabalho foi delineado de acordo com o esquema apresentado na figura 2.

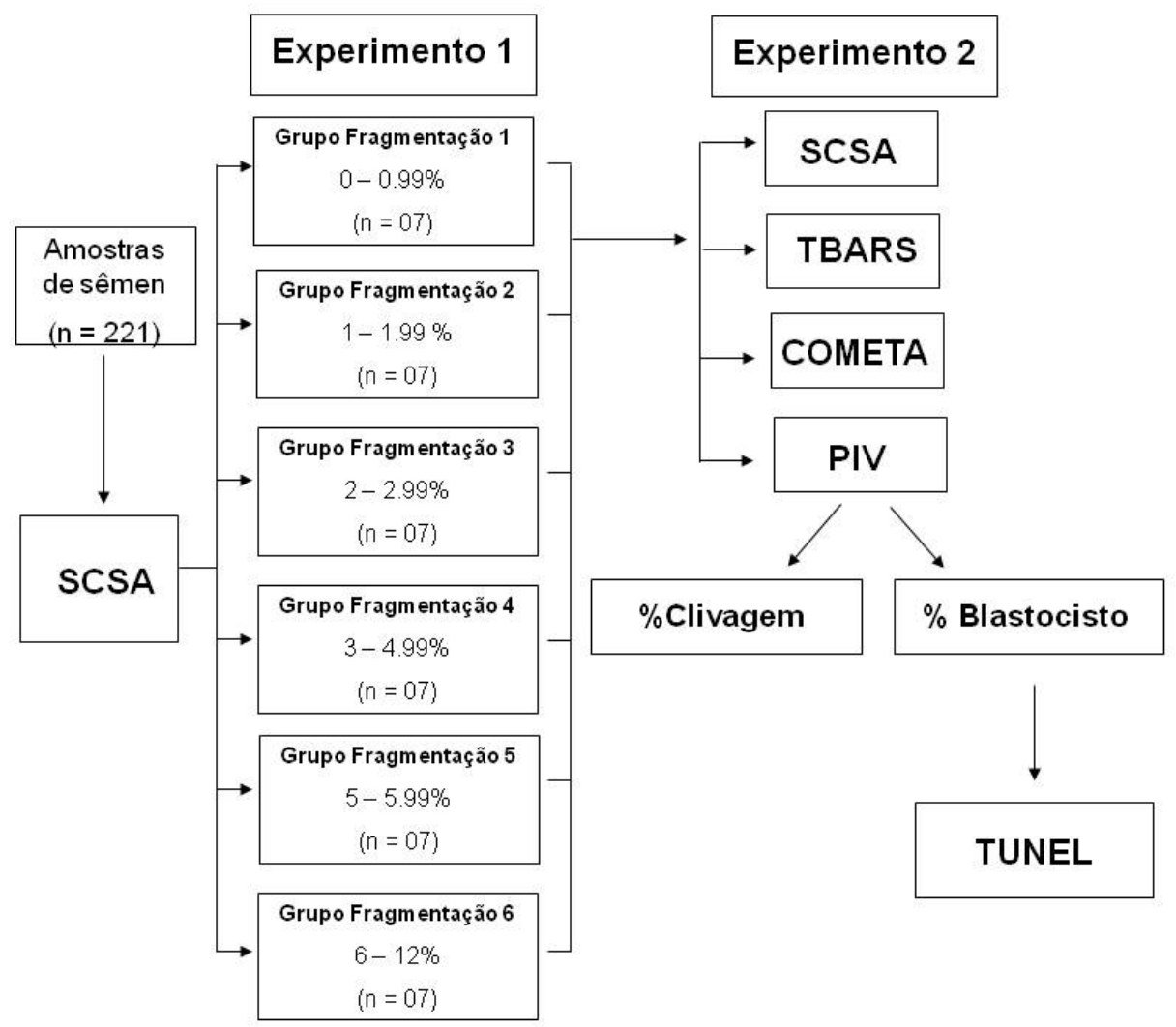

Figura 2 - Esquema ilustrativo do delineamento experimental. SCSA: ensaio de estrutura de cromatina espermática; TBARS: substâncias reativas ao ácido tiobarbitúrico; Cometa: ensaio de Cometa Alcalino. 


\section{Resultados}




\section{RESULTADOS}

Os resultados deste estudo estão apresentados abaixo.

\subsection{EXPERIMENTO 1: AVALIAÇÃO DA SUSCEPTIBILIDADE DA FRAGMENTAÇÃO DE DNA ESPERMÁTICO PELO ENSAIO DE ESTRUTURA DE CROMATINA ESPERMÁTICA (SCSA) PARA A DIVISÃO DOS GRUPOS EXPERIMENTAIS}

A frequência de indivíduos presentes em cada grupo experimental (1 a 6), após a avaliação da susceptibilidade da fragmentação de DNA espermático pelo ensaio de SCSA está representado no gráfico 1.

O grupo 1 apresentou menor frequência de indivíduos em relação aos grupos 2 e 3 . Os grupos 2 e 3 não apresentaram diferença significativa entre si, mas foram os grupos com maior frequência de indivíduos, quando comparados aos grupos 1, 4, 5 e 6 . Os grupos 1, 5 e 6 não apresentaram diferença significativa entre si, mas foram os grupos que apresentaram menor frequência de indivíduos, quando comparados aos grupos 2, 3 e 4 (Gráfico 1). 


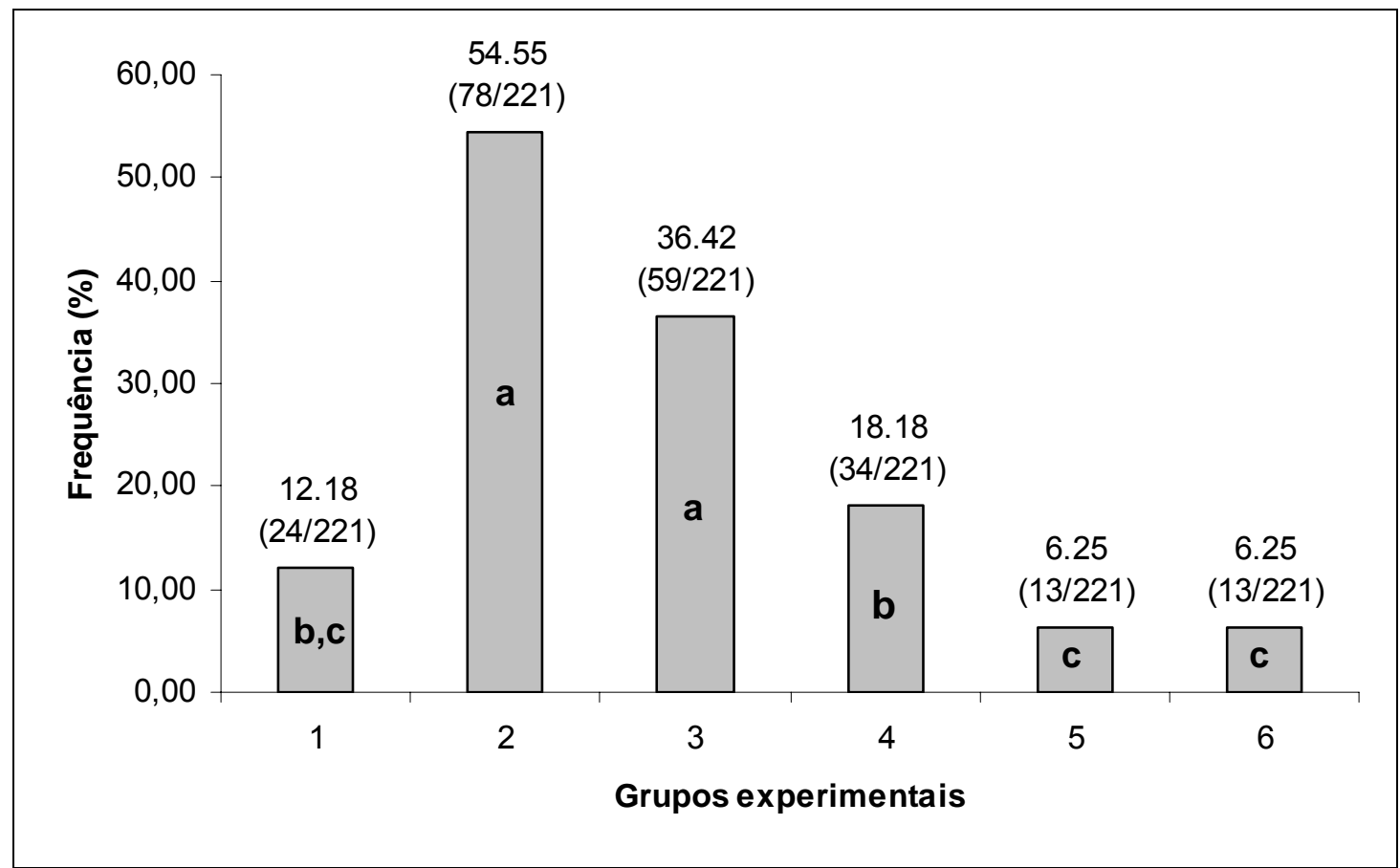

Gráfico 1 - Frequência média dos indivíduos distribuídos entre os grupos experimentais (1 a 6) após a avaliação da susceptibilidade à fragmentação de DNA espermático pelo ensaio de SCSA.

\subsection{EXPERIMENTO 2: INFLUÊNCIA PATERNA NA PRODUÇÃO IN VITRO DE EMBRIOÕES}

Os resultados das avaliações espermáticas estão descritos abaixo.

\subsubsection{Motilidade espermática}

O grupo 1 apresentou menor motilidade espermática em relação ao grupo 4 (36,67 $\pm 7,15$ e 58,33 $\pm 4,77$, respectivamente, $p<0,05)$. Não foi verificada diferença significativa entre os demais grupos experimentais (Gráfico 2). 


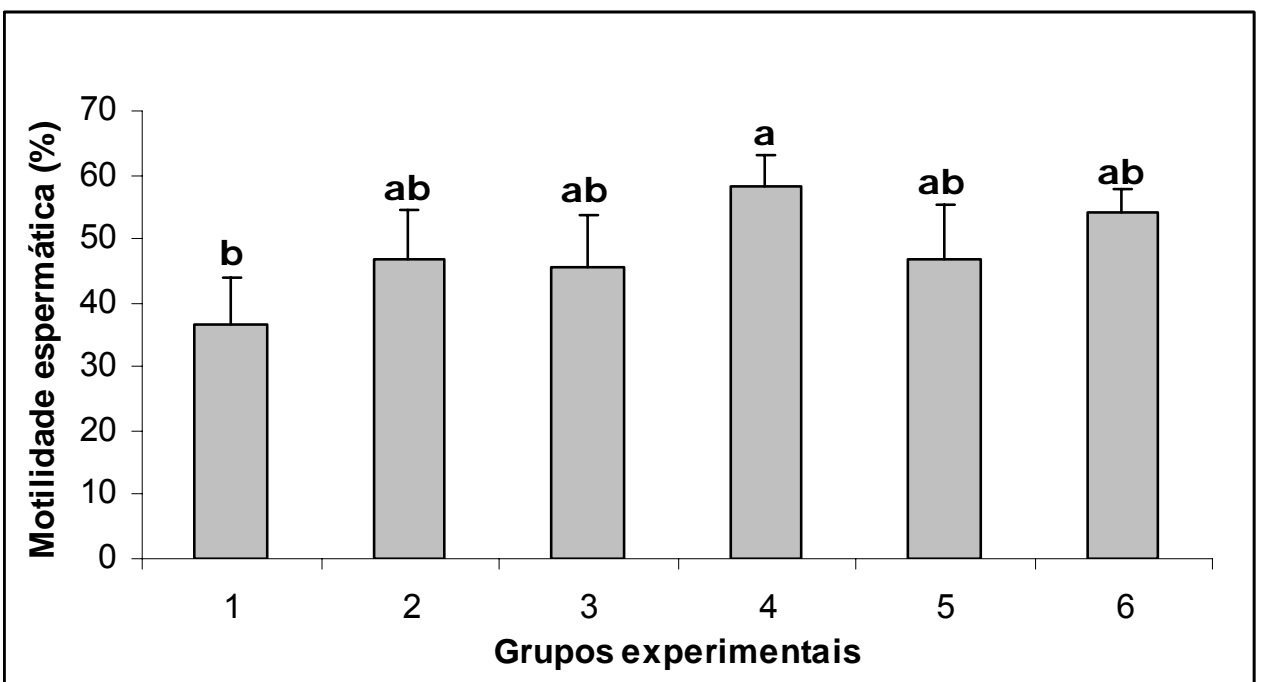

Gráfico 2 - Média da motilidade espermática (\%) das amostras de sêmen dos touros distribuídos nos distintos grupos experimentais (1 a 6).

\subsubsection{Ensaio SCSA}

A susceptibilidade à fragmentação do DNA do grupo 1 não diferiu da apresentada pelo grupo 2. No entanto, o grupo 1 apresentou menor susceptibilidade à fragmentação de DNA espermático, quando comparado ao grupo 5 (4,78 $\pm 1,43$ e 7,77 $\pm 1,26$, respectivamente, $p<0,05)$. O grupo $2(3,49$ $\pm 0,78)$ apresentou susceptibilidade inferior quando comparado aos grupos 3 , 4,5 e $6(6,07 \pm 0,69,5,73 \pm 0,59,7,77 \pm 1,26$ e 5,57 $\pm 0,59$, respectivamente, p<0,05) (Gráfico 3). 


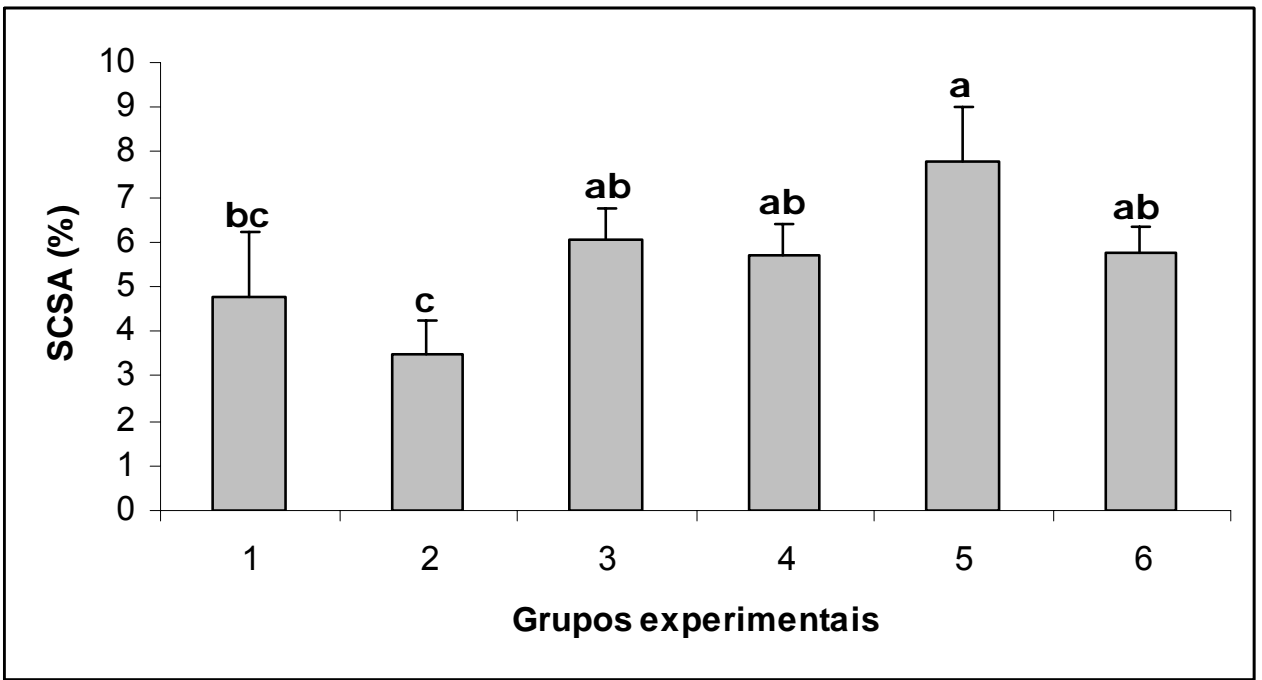

Gráfico 3 - Média da susceptibilidade à fragmentação de DNA espermático das amostras dos touros dos grupos experimentais ( 1 a 6 ), avaliada pelo ensaio de SCSA.

\subsubsection{Ensaio Cometa Alcalino}

Os resultados do ensaio Cometa alcalino estão apresentados na tabela 1. Não houve diferença significativa entre os grupos experimentais (1 a 6) em relação às variáveis mensuradas. 
Tabela 1- Variáveis (média \pm erro padrão) avaliadas pelo Comet Score ${ }^{\circledR}$ utilizado na análise de dados do ensaio Cometa das células espermáticas de touros distribuídos nos diferentes grupos experimentais ( 1 a 6 )

\begin{tabular}{|c|c|c|c|c|c|c|c|}
\hline & \multicolumn{6}{|c|}{ Grupos experimentais $^{1}$} & \multirow[t]{2}{*}{$\begin{array}{l}\text { Valor } \\
\text { de } P^{2}\end{array}$} \\
\hline & 1 & 2 & 3 & 4 & 5 & 6 & \\
\hline \multicolumn{8}{|l|}{ COMETA TOTAL } \\
\hline Comprimento (px) & $63,82 \pm 6,21$ & $61,50 \pm 3,81$ & $74,03 \pm 10,20$ & $72,68 \pm 9,00$ & $61,10 \pm 8,34$ & $52,91 \pm 4,13$ & 0,1495 \\
\hline Área (px) & $2919,09 \pm 508,99$ & $2722,34 \pm 319,70$ & $3605,57 \pm 795,36$ & $3522,87 \pm 708,83$ & $2493,81 \pm 539,74$ & $1979,98 \pm 268,00$ & 0,0872 \\
\hline Intensidade media $(p x)$ & $50,44 \pm 4,58$ & $48,93 \pm 2,72$ & $51,52 \pm 4,23$ & $50,89 \pm 3,46$ & $42,53 \pm 1,72$ & $48,50 \pm 4,15$ & 0,6209 \\
\hline Olive moment (px) & $0,82 \pm 0,28$ & $2,16 \pm 1,17$ & $2,06 \pm 1,29$ & $2,26 \pm 1,87$ & $3,92 \pm 2,39$ & $1,33 \pm 0,38$ & 0,5578 \\
\hline \multicolumn{8}{|l|}{ CABEÇA DO COMETA } \\
\hline Intensidade média (px) & $50,32 \pm 4,39$ & $49,76 \pm 2,94$ & $51,97 \pm 4,39$ & $51,49 \pm 2,76$ & $43,81 \pm 1,20$ & $49,16 \pm 4,05$ & 0,7329 \\
\hline$\%$ DNA (px) & $95,70 \pm 0,94$ & $92,73 \pm 2,55$ & $94,65 \pm 2,19$ & $93,12 \pm 4,38$ & $90,32 \pm 1,95$ & $92,03 \pm 1,60$ & 0,7151 \\
\hline \multicolumn{8}{|l|}{ CAUDA DO COMETA } \\
\hline Comprimento (px) & $2,83 \pm 1,52$ & $6,63 \pm 3,30$ & $5,57 \pm 3,30$ & $6,62 \pm 5,53$ & $11,29 \pm 6,48$ & $0,50 \pm 0,13$ & 0,5873 \\
\hline Intensidade média (px) & $145,60 \pm 56,15$ & $93,56 \pm 21,99$ & $116,59 \pm 17,10$ & $171,70 \pm 28,70$ & $62,23 \pm 21,70$ & $83,37 \pm 23,39$ & 0,1379 \\
\hline$\%$ DNA (px) & $4,30 \pm 0,94$ & $7,27 \pm 2,55$ & $5,35 \pm 2,19$ & $6,88 \pm 4,38$ & $9,68 \pm 1,95$ & $7,97 \pm 1,60$ & 0,2468 \\
\hline Tail moment (px) & $0,42 \pm 0,28$ & $2,32 \pm 1,71$ & $2,21 \pm 1,63$ & $2,80 \pm 2,67$ & $4,30 \pm 3,34$ & $0,82 \pm 0,39$ & 0,4858 \\
\hline
\end{tabular}

1 Grupos experimentais divididos de acordo com o índice de fragmentação de DNA espermático avaliado pelo ensaio SCSA. Grupo 1 (0 a $0,99 \%$ de fragmentação de DNA espermático), Grupo 2 (1 a 2,99\%), Grupo 3 (2 a 2,99\%9), Grupo 4 (3 a 4,99\%), Grupo 5 (5 a 5,99\%) e Grupo 6 (6 a 57,78\%).

${ }^{2}$ Valores de $\mathrm{P}$ referentes ao efeito dos grupos experimentais sobre as variáveis respostas 


\subsubsection{Ensaio de substâncias reativas ao ácido tiobarbitúrico - TBARS}

O gráfico 4 mostra as médias e os respectivos erros padrões da susceptibilidade das células espermáticas frente ao estresse oxidativo. Não foram observadas diferenças significativas entre os grupos experimentais.

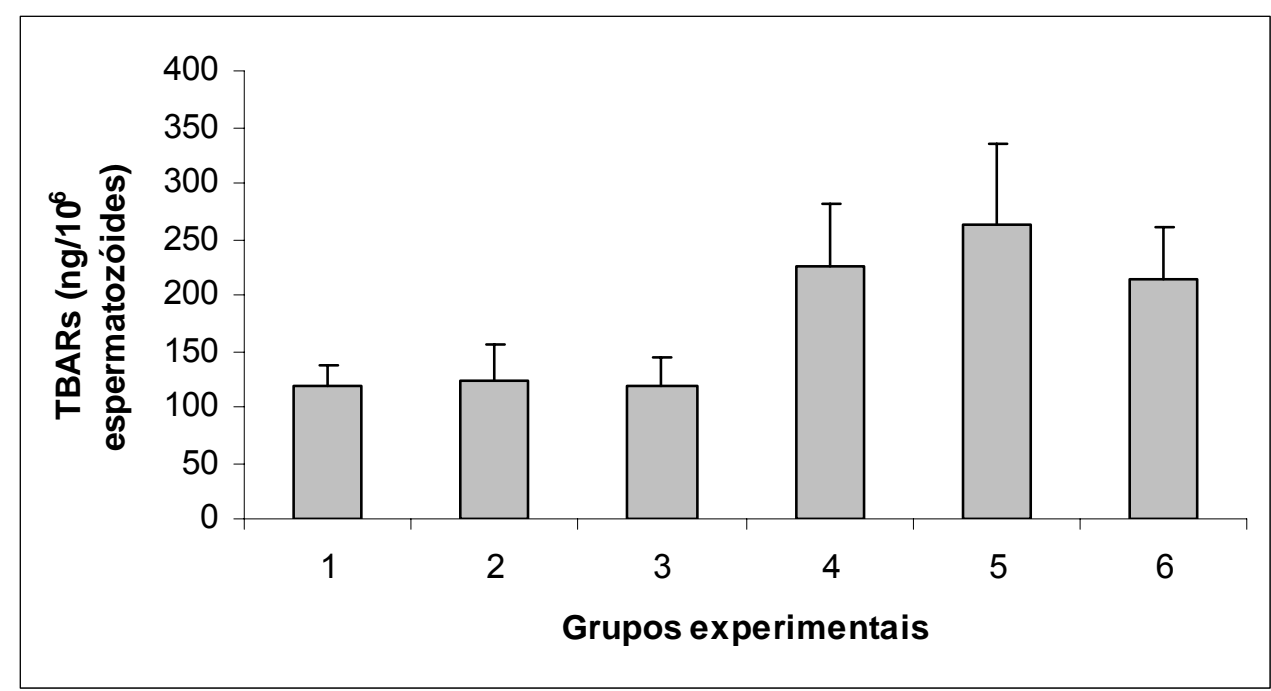

Gráfico 4 - Média da susceptibilidade das células ao estresse oxidativo mensurado nas amostras de sêmen de touros dos distintos grupos experimentais.

\subsection{PRODUÇÃO IN VITRO DE EMBRIÕES}

Para cada um dos sete animais aleatoriamente selecionados nos seis grupos de fragmentação de DNA espermático selecionados para a produção in vitro de embriões foram avaliados os índices de clivagem embrionária (\%CLIV) e o de blastocistos (\%BL). Não foram observadas diferenças entre os índices de clivagem (Gráfico 5) e o de blastocisto (Gráfico 6), entre os grupos experimentais. 


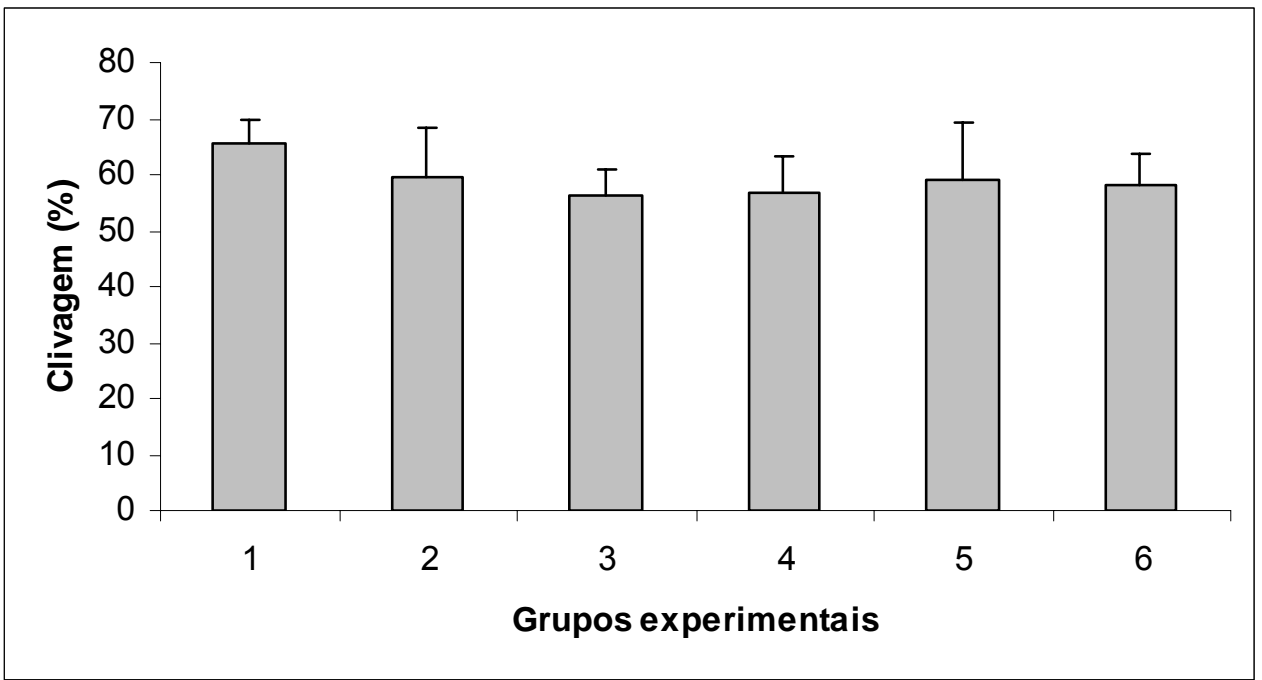

Gráfico 5 - Índice de clivagem (\%) dos embriões produzidos com sêmen de touros de cada grupo experimental (1 a 6).

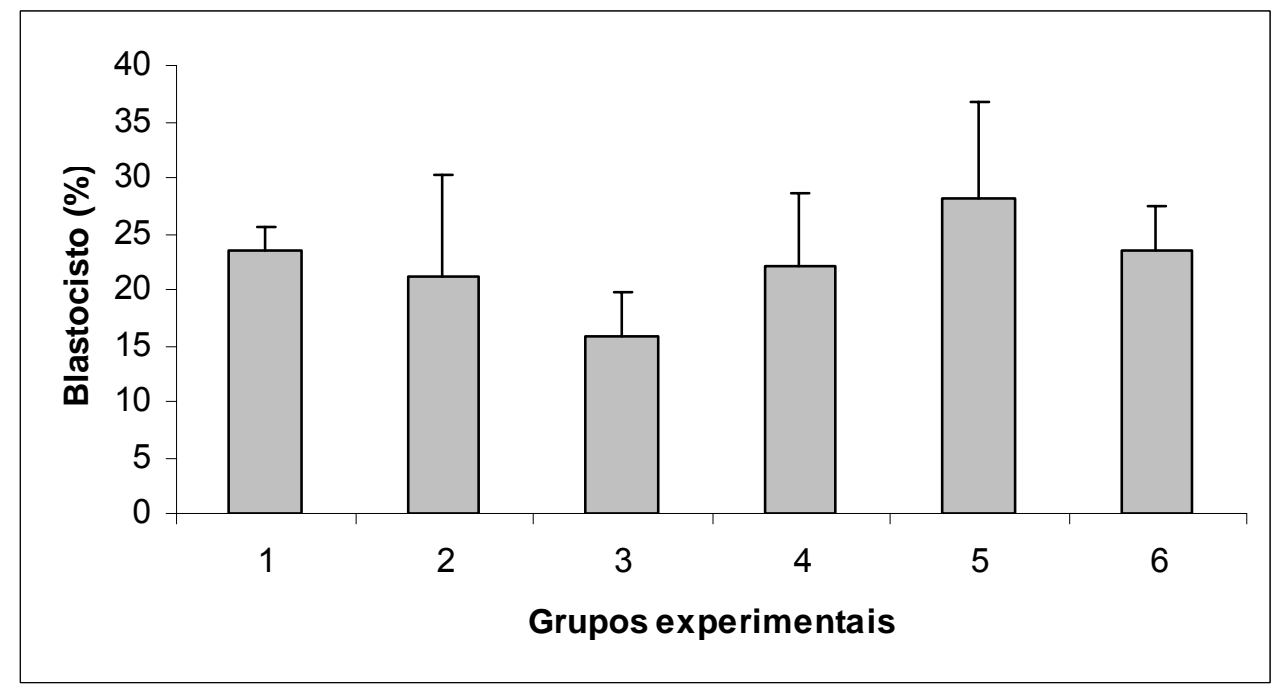

Gráfico 6 - Índice de blastocisto (\%) produzido com sêmen de touros de cada grupo experimental (1 a 6$)$.

\subsubsection{Ensaio de TUNEL}

Os embriões controle positivo apresentaram reação de TUNEL em todos os núcleos e os embriões controle negativo não apresentaram reação de TUNEL em nenhum núcleo (Figura 3). 

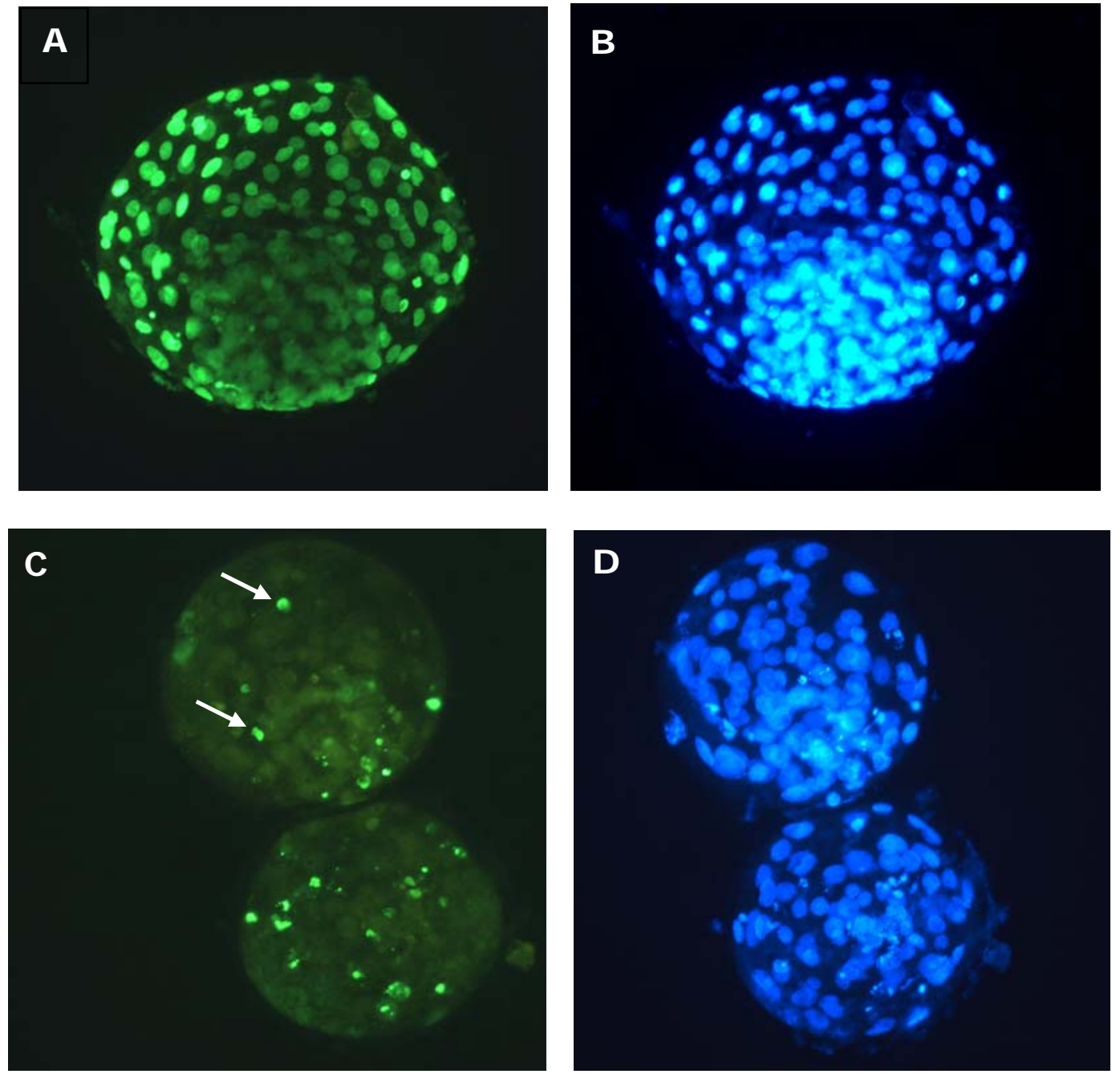

Figura 3 - Imagens ilustrativas da avaliação de fragmentação de DNA em embriões em estádio de blastocisto (D7) pelo Ensaio de TUNEL. (A) Blastocisto controle positivo com todos os núcleos corados; (B) Blastocisto corado com Hoechst 33342 para avaliação do número total de núcleos. (C) Blastocisto com células positivas marcadas para o ensaio TUNEL (setas). (D) Blastocisto corado com Hoechst 33342 para avaliação do número total de núcleos

O número total de núcleos (NT) e de núcleos positivos para reação de TUNEL $(T+)$, não diferiram entre os grupos experimentais (Gráficos 7 e 8 , respectivamente). 


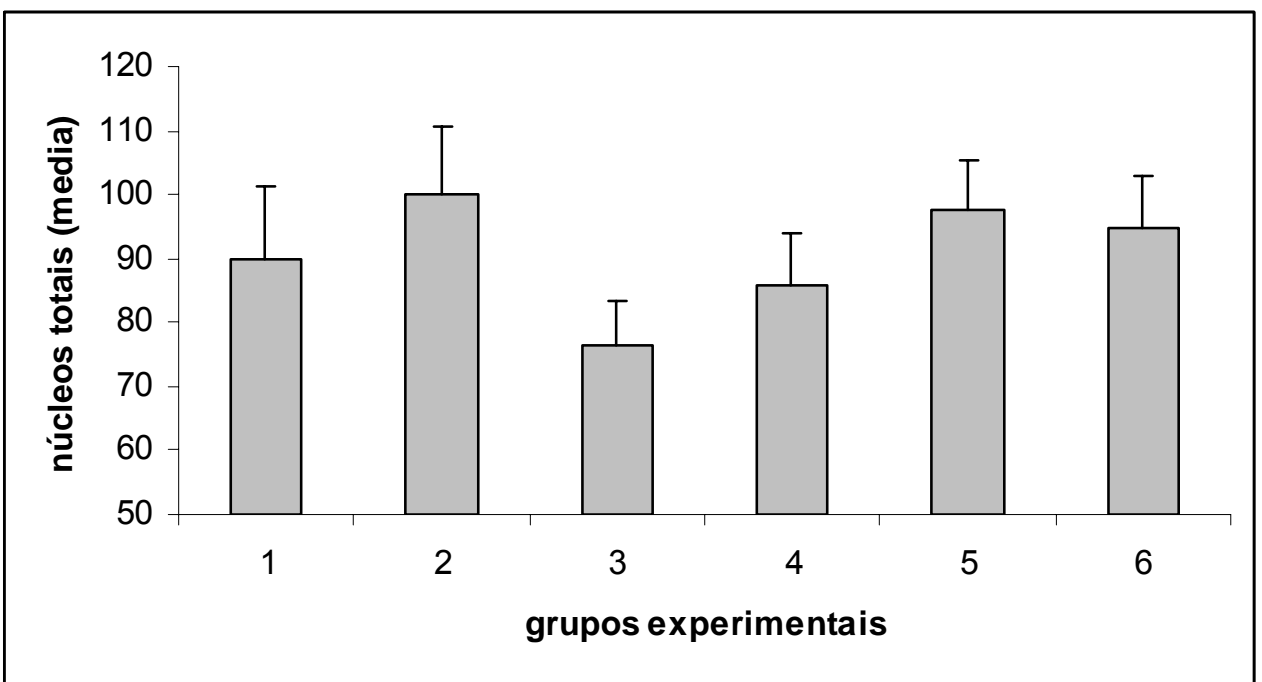

Gráfico 7 - Média do número total de núcleos dos embriões produzidos in vitro com sêmen de touros de cada grupo experimental (1 a 6)

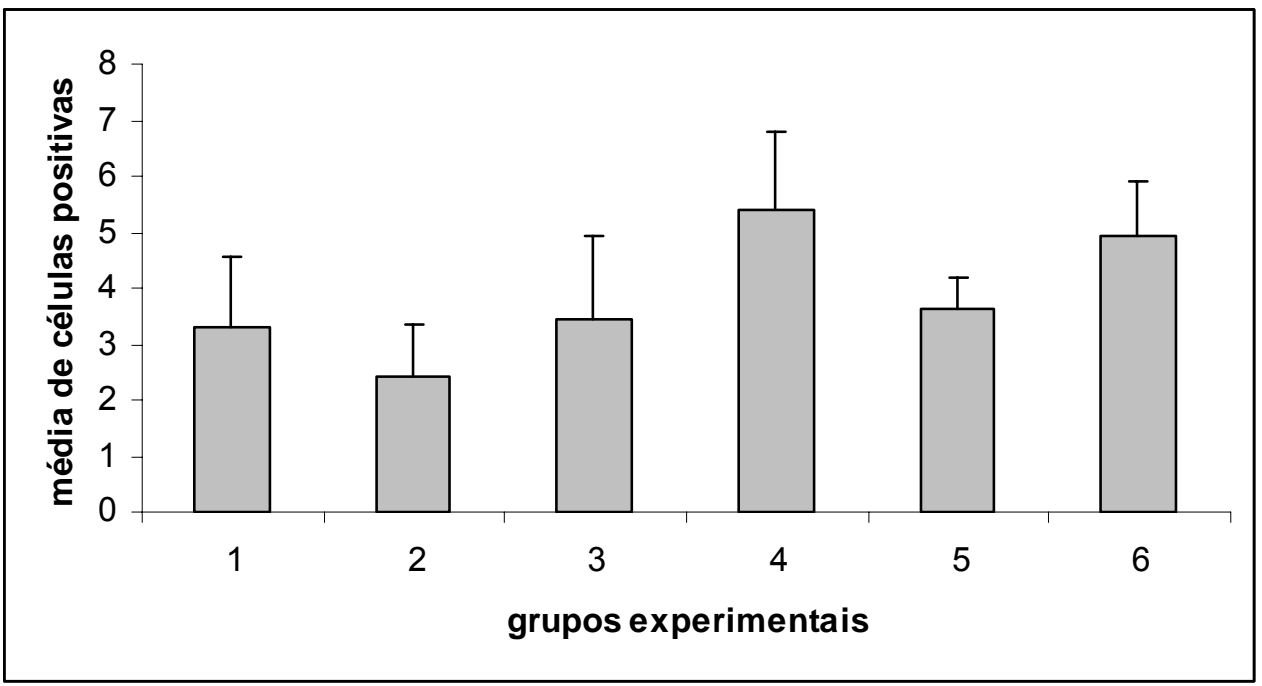

Gráfico 8 - Número médio de células positivas dos embriões produzidos in vitro com sêmen de touros de cada grupo experimental (1 a 6).

\subsection{CORRELAÇÕES}

Os índices de correlação entre motilidade, índice de clivagem, índice de blastocisto, número de núcleos totais (NT), número de núcleos positivos para reação de TUNEL $(\mathrm{T}+)$, TBARS, SCSA-FIV e as mensurações do ensaio Cometa alcalino (comprimento do Cometa, área do Cometa, intensidade média 
do Cometa, intensidade média da cabeça do Cometa, porcentagem de DNA na cabeça do Cometa, comprimento da cauda do Cometa, intensidade média do Cometa, porcentagem de DNA na cauda do Cometa, tail moment e Olive moment) estão apresentados na tabela 2. Apenas os índices de correlação com nível descritivo significativo $(p<0,05)$ foram incluídos na tabela.

Foi observada correlação negativa entre a intensidade média do Cometa e o índice de blastocistos produzidos in vitro. O índice de blastocisto também apresentou correlação negativa com a intensidade média da cabeça do Cometa e ao ensaio TBARS. O ensaio TBARS apresentou correlação negativa com 0 índice de clivagem dos embriões produzidos in vitro. Por outro lado 0 ensaio TBARS apresentou correlação positiva com os ensaios SCSA e TUNEL. 
Tabela 2 - Correlações ( $r$ ) e nível de significância $(p)$ entre as variáveis respostas mensuradas

\begin{tabular}{|c|c|c|c|c|c|c|c|c|c|c|c|c|c|c|c|c|}
\hline & 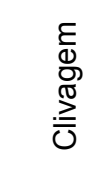 & $\begin{array}{l}\frac{0}{0} \\
\frac{0}{0} \\
\frac{0}{0} \\
\frac{0}{0} \\
\frac{0}{0}\end{array}$ & 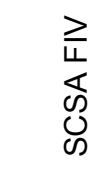 & 々 & $\begin{array}{l}\vec{u} \\
\stackrel{\rightleftarrows}{丂}\end{array}$ & 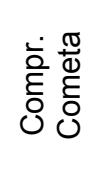 & 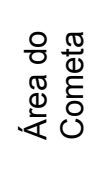 & 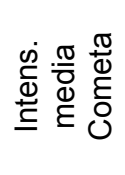 & 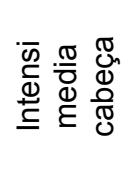 & 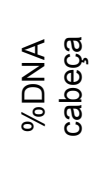 & 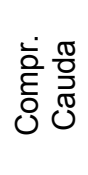 & 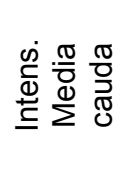 & $\begin{array}{l}\nwarrow \frac{\pi}{O} \\
\frac{0}{0} \\
\text { 잉 }\end{array}$ & 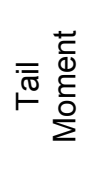 & 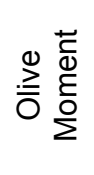 & $\begin{array}{l}\text { O } \\
\frac{1}{\alpha} \\
\stackrel{m}{F}\end{array}$ \\
\hline Motilidade & * & * & * & * & * & * & * & * & * & * & * & * & * & * & * & * \\
\hline Clivagem & 1,00 & * & * & * & * & * & * & * & * & * & * & * & * & * & * & $\begin{array}{l}-0.417 \\
(0,009)\end{array}$ \\
\hline Blastocisto & * & 1,00 & * & * & * & * & * & $\begin{array}{c}-0.375 \\
(0,02)\end{array}$ & $\begin{array}{l}-0.389 \\
(0,016)\end{array}$ & * & * & * & * & * & * & $\begin{array}{l}-0.367 \\
(0,023)\end{array}$ \\
\hline SCSA FIV & * & * & 1,00 & * & * & * & * & * & * & * & * & * & * & * & * & $\begin{array}{c}0.416 \\
(0,009)\end{array}$ \\
\hline Núcleos totais (NT) & * & * & * & 1,00 & * & * & * & * & * & * & * & * & * & * & * & * \\
\hline TUNEL & * & * & * & * & 1,00 & * & * & * & * & * & * & * & * & * & * & $\begin{array}{c}0.417 \\
(0,009)\end{array}$ \\
\hline
\end{tabular}

* não significativo $(p \geq 0,05)$

SCSA=ensaio de estrutura de cromatina espermática; NT= número de núcleos totais; TUNEL= células positivas para a reação de TUNEL; compr. Cometa=comprimento do Cometa; Intens. média Cometa= intensidade média do Cometa; \%DNA cabeça= porcentagem de DNA presente na cabeça do Cometa; Compr. Cauda= comprimento da cauda do Cometa; Intens. média cauda= intensidade média da cauda do Cometa; \%DNA cauda= porcentagem de DNA presente na cauda do Cometa; TBARS =ensaio de substâncias reativas ao ácido tiobarbitúrico 


\section{DISCUSSÃO}

Animais que apresentam alta fertilidade a campo podem não apresentar o mesmo desempenho quando submetidos à reprodução in vitro. Entretanto, as causas desta diferença de fertilidade ainda não foram totalmente elucidadas. $O$ presente trabalho investigou a influência da fragmentação de DNA espermático no desenvolvimento embrionário in vitro na espécie bovina.

\subsection{ENSAIO SCSA}

Amostras de sêmen de 221 touros foram avaliadas pelo ensaio SCSA para verificar a incidência da fragmentação de DNA espermático em uma amostragem de animais da espécie bovina. Apesar de ser um teste desafio que avalia a susceptibilidade do DNA espermático frente à denaturação ácida in situ, esta técnica tem a capacidade de estimar, com acurácia, a porcentagem de espermatozóides com dano de cromatina (VIRRO; LARSON-COOK; EVENSON, 2004; ANDRABI, 2007). Por ser uma técnica simples e de rápida execução, facilita a avaliação de um grande número de amostras de sêmen. $O$ índice de fragmentação de DNA espermático dos animais utilizados no presente estudo variou de $0,46 \%$ a $11,91 \%$. Estes dados estão de acordo com os estudos de avaliação de dano de DNA espermático na espécie bovina pelo ensaio SCSA descritos na literatura (BOCHENEK et al., 2001).

Entretanto, quando comparados com a espécie humana, estes índices são bastante modestos. Em humanos, diversos trabalhos verificaram a influência do dano de cromatina espermática no desenvolvimento embrionário. Segundo Virro, Larson-Cook e Evenson (2004), pacientes com mais de 30\% das células espermáticas com dano de DNA, avaliados pelo SCSA, apresentam diminuição significativa no índice de blastocisto e baixo sucesso de gestação. Neste sentido, o índice de fragmentação de DNA espermático descrito no presente estudo pode não ter sido suficiente para causar um efeito negativo nos índices de PIV de embriões em bovinos. 
Já foi descrito que o ensaio SCSA é uma das avaliações de eleição para diagnosticar fragmentação de DNA espermático em humanos. No entanto, ao escolher um ensaio para avaliar a qualidade da cromatina deve-se considerar qual tipo de lesão que este teste é capaz de identificar (quebras simples ou de dupla fita de DNA) e ainda qual o nível de acessibilidade à cromatina o teste promove.

Segundo Shaman e Ward (2006), é possível acessar a cromatina espermática em três níveis. Segundo estes autores, o primeiro nível de acesso e o mais vulnerável é a região de ligação entre os complexos DNA-protamina que contém DNA ainda associado às histonas. Estas regiões são mais sensíveis à ação de enzimas do que as regiões de DNA ligadas à protamina. $O$ segundo nível refere-se às fitas de DNA que estão na superfície dos complexos DNA-protamina. Estas porções podem ser os locais mais susceptíveis à ação de enzimas, porém as protaminas que estão intimamente ligadas ao DNA podem impedir a atividade destas enzimas. Por fim, o terceiro nível de acesso à cromatina refere-se a maioria das fitas de cromatina localizada no interior dos complexos DNA-protamina, que são totalmente recobertas por outras fitas de DNA associadas à protamina. Estas fitas não são acessíveis às proteínas exógenas, ao menos enquanto estes complexos estiverem compactos.

No ensaio SCSA, os espermatozóides não são tratados com uma solução ácida capaz de remover as protaminas, ou seja, o teste só consegue avaliar as alterações de DNA no primeiro nível de acesso da cromatina (SHAMAN; WARD, 2006). Apesar desta limitação, como o DNA é altamente compactado, este só pode ser denaturado se houver uma quebra de DNA préexistente. Neste sentido, o ensaio SCSA é capaz de mensurar as quebras simples ou duplas de DNA. Assim, esta instabilidade de cromatina, mesmo que em regiões mais susceptíveis a danos, pode ser um indício de que estes danos podem ser agravados frente à outras situações de estresse, o que pode prejudicar o desenvolvimento embrionário, ou frente a um ensaio que consiga remover protaminas como o ensaio Cometa Alcalino. Desta forma os ensaios SCSA e Cometa demonstram ser complementares, sendo que o SCSA por ser rápido e fácil pode ser utilizado para rastrear os indivíduos com danos de fragmentação de DNA e o Cometa um ensaio utilizado para quantificar o 
número de células e analisar o grau do dano das células avaliadas em uma determinada população de espermatozóides..

No presente trabalho, os animais foram divididos em 6 grupos experimentais, de acordo com o índice de fragmentação de DNA espermático avaliado pelo SCSA. Os animais que foram alocados nos grupos 5 e 6 apresentavam os maiores índices de fragmentação (5 a 5,99\% e 6 a 12\%, respectivamente), contudo estes dois grupos foram os que apresentaram menor número de indivíduos em relação aos outros grupos $(p<0,05)$. Por outro lado, os grupos que apresentaram o maior número de indivíduos foram os grupos 2 e 3 que representam índice fragmentação de DNA espermático de até $2,99 \%$, ou seja, mais de $60 \%$ dos animais avaliados pelo SCSA apresentaram no máximo $2,99 \%$ de índice de fragmentação de DNA espermático. Alguns fatores podem explicar estes resultados.

As amostras de sêmen avaliadas neste trabalho foram obtidas em CCPs, ou seja, animais geneticamente selecionados. A seleção genética data da época do período Neolítico (10.000 a.C a 3.000 a.C), quando ocorreu a domesticação dos animais. Neste período, a seleção genética foi feita baseada na observação visual do fenótipo destes animais. Contudo, a seleção genética em larga escala passou a ser empregada de fato após o uso da técnica de inseminação artificial. A primeira inseminação artificial feita com sucesso foi realizada, em cães, por Spallanzani em 1784, mas só a partir de 1907 esta tecnologia foi empregada em outras espécies (animais de produção, galinhas e coelhos) pelo russo Ivanoff. Em 1936 foi o marco do início da seleção genética para a espécie bovina com a criação da primeira cooperativa de inseminação artificial para gado de leite (FOOTE, 2002). Além da seleção genética, os touros nas CCPs são mantidos em condições ótimas de manejo alimentar, sanitário e reprodutivo. Estes animais também devem apresentar alta eficiência na produção de espermatozóides, já que participam de uma rotina de coleta de sêmen que pode ocorrer até 3 vezes por semana, dependendo do animal.

Ainda que o espermatozóide na espécie bovina não apresente um alto índice de fragmentação de DNA, a avaliação da qualidade da cromatina desta célula não deve ser descartada, uma vez que própria manipulação do sêmen, como a criopreservação, pode causar danos ao espermatozóide (TARTAGLIONE; RITTA, 2004). Durante a espermatogênese, a célula que 
apresentar danos de cromatina pode ser eliminada por apoptose (BAUM; McCALL, 2005); contudo, o espermatozóide com dano de cromatina pode sobreviver e participar do processo de fecundação (FATEHI et al., 2006). Neste caso, o desenvolvimento embrionário inicial não é prejudicado, uma vez que esta fase é praticamente dependente do genoma materno. Entretanto, pode ocorrer o bloqueio no momento da ativação do genoma embrionário, já que nesta fase são necessárias as informações oriundas do gameta masculino. Já foram relatadas na literatura as conseqüências que a fragmentação de DNA espermático pode causar na prole. Segundo Brinkworth (2000), Aitken e Krausz (2001) e Perreault (2003), algumas doenças como câncer infantil e infertilidade podem ser decorrentes das alterações de cromatina espermática. A fragmentação de DNA espermático pode apresentar algumas causas, sendo que as mais comuns são deficiência de protamina, a apoptose espermática e danos causados pelas EROs.

A cromatina de espermatozóides mamíferos maduros difere em composição e estrutura da cromatina de células somáticas (ROCHA et al., 2002; McLAY; CLARKE, 2003). A troca de histonas por protaminas promove maior compactação e rigidez do núcleo espermático, conferindo mais resistência contra injúrias físicas e químicas durante o processo de fecundação (OLIVA, 2006; CARRELL; EMERY; HAMMOUND, 2007).

Em humanos, não é apenas o aumento (ou a diminuição) da P1 ou da P2 que pode acarretar em dano no DNA do espermatozóide. Segundo Aoki, Liu e Carrel (2005), a relação P1/P2 também é importante para predizer a fertilidade sendo a razão 1:1 a ideal. Segundo Oliva (2006) estas alterações da razão P1/P2 podem ser conseqüências de falha generalizada na substituição das histonas por protaminas durante a espermiogênese. Em camundongos, também foi observado que o desequilíbrio da razão P1/P2 altera a integridade do DNA e o subseqüente desenvolvimento embrionário (SUGANUMA et al., 2005).

Em um estudo realizado por Simões et al. (2009), os autores demonstraram que alterações de protamina nas células espermáticas de touros não parece influenciar a fertilidade destes animais. Considerando as diferenças que existem entre a protaminação em humanos e bovinos, os resultados deste estudo podem ter duas explicações. Pelo fato dos touros não possuírem P2, a 
P1 é a única protamina responsável pela compactação do DNA espermático nesta espécie. Por isso, para manter o DNA espermático intacto e permitir que o espermatozóide consiga carrear o genoma até o oócito no momento da fecundação, a P1 deve ser menos susceptível a danos, quando comparado com a P1 da espécie humana. Além disso, em humanos existem estudos mostrando que alterações de P2 são mais comuns em pacientes inférteis do que nos férteis (CARRELL et al., 2001), o que não pode ser atribuído aos animais utilizados no trabalho que provinham de CCPs (SIMÕES et al., 2009).

A segunda causa de fragmentação de DNA espermático de espermatozóides ejaculados descrita na literatura está relacionada à falha na apoptose espermática durante a espermatogênese. Como visto anteriormente, a baixa produção de espermatozóides não é capaz de desencadear o processo de apoptose (FRANCAVILLA et al., 2000). Sendo assim, em indivíduos com alta produção de espermatozóides, a apoptose pode ocorrer de forma mais intensa, ou seja, a eliminação de células defeituosas e/ou com dano de DNA pode ser mais eficiente nestes indivíduos quando comparados com os animais que não estão em regime de coleta de sêmen nos CCPs.

Outra origem importante de fragmentação de DNA espermático ocorre pelos danos causados pela formação de EROs. Além das causas já descritas anteriormente, o processo de criopreservação também pode contribuir para a formação de EROs no sêmen. Segundo Amirat et al. (2005) podem ocorrer efeitos deletérios ao espermatozóide durante as primeiras diluições do sêmen e até mesmo durante o processo de congelação. O objetivo cerne deste trabalho consistia em avaliar os danos espermáticos voltados à fragmentação do DNA, ou seja, relacionados à cromatina. No entanto, analisando os resultados, os índices de fragmentação de DNA mostram que possivelmente a criopreservação de espermatozóide, embora seja um processo que cause alterações celulares, não causou dano à cromatina.

Contudo, ao avaliar a produção de EROs, o mesmo processo de criopreservação parece ter aumentado a produção destes subprodutos de reações. A consequência do aumento de EROs é a maior susceptibilidade à fragmentação de DNA espermático, fato confirmado pelos resultados apresentados, já que houve correlação positiva entre o ensaio SCSA e o TBARS $(r=0,416 ; p=0,009)$, o que corrobora com os dados de literatura 
(AITKEN et al., 1992; AITKEN; KRAUSZ, 2001; MAKKER; ARGAWAL; SHARMA, 2009). Este resultado sugere que quanto maior a susceptibilidade da célula ao estresse oxidativo, maior a susceptibilidade da mesma à fragmentação de DNA espermático.

\subsection{MOTILIDADE ESPERMÁTICA}

Neste estudo, uma das avaliações realizadas foi a motilidade espermática das amostras dos touros de cada um dos grupos experimentais. Apesar da diferença significativa encontrada entre o grupo 1 e $4(36,67 \pm 7,15$ e $58,33 \pm 4,77$, respectivamente; $p<0,05)$, todos os grupos apresentaram motilidade adequada para sêmen criopreservado que deve ser de no mínimo $30 \%$. Diversos estudos em humanos têm demonstrado que diferenças de fertilidade podem estar relacionadas à diminuição da motilidade espermática (JANUSKAUKAS et al., 2000; BRITO et al., 2003; TARTAGLIONE; RITTA, 2004; RODRIGUEZ-MARTINEZ, 2007); entretanto, para a espécie bovina a correlação entre a motilidade e a fertilidade a campo é baixa (JANUSKAUSKAS; JOHANNISSON; RODRIGUEZ-MARTINEZ, $\quad 2000$; RECKOVA et al., 2008).

Em humanos, as técnicas de reprodução assistida são empregadas em casos de problemas de fertilidade. Diferente dos bovinos, em humanos não existe seleção genética e não é possível controlar alguns hábitos de vida (tabagismo, álcool, alimentação, estresse); além disso, estes pacientes que procuram as clínicas de reprodução assistida, normalmente apresentam alterações nos parâmetros seminais (motilidade, concentração, morfologia) e até mesmo doenças como a varicocele que é uma das causas de infertilidade masculina.

Por outro lado, os touros que participam de coletas de sêmen em CCPs são selecionados geneticamente e dificilmente são animais com alterações dos padrões seminais. Neste sentido, diversos fatores que poderiam afetar a fertilidade, já foram minimizados antes da criopreservação de sêmen. A diferença encontrada de motilidade espermática entre os grupos experimentais 
neste estudo pode estar relacionada aos diferentes métodos de congelação de sêmen ou crioprotetores utilizados e por este motivo apresentar variação individual, já que as amostras de sêmen foram obtidas em diferentes CCPs. Vale ressaltar que para este estudo, a motilidade não foi um parâmetro utilizado para a divisão dos animais nos grupos experimentais, já que esta avaliação é subjetiva; além disso, diversas alterações nos espermatozóides não refletem em mudança de motilidade ou da capacidade fecundante. A correlação entre motilidade espermática e fertilidade varia muito entre os trabalhos publicados na literatura. De acordo com Rodríguez-Martinez (2007), mesmo utilizando análise seminal computadorisada (Computer-Assisted Sperm Analysis - CASA), ainda existem variações entre características de motilidade como linearidade e fertilidade a campo. Neste sentido, outros testes mais acurados foram usados para a divisão dos animais nos grupos experimentais.

\subsection{ENSAIO COMETA ALCALINO}

As amostras de sêmen dos animais selecionados para a PIV de embriões foram submetidas à avaliação da fragmentação de DNA espermático tanto pelo ensaio SCSA como pelo ensaio Cometa. Diferentemente do SCSA que avalia a susceptibilidade de fragmentação de DNA frente a um desafio ácido, o ensaio Cometa é capaz de mensurar de fato a fragmentação de DNA de cada célula individualmente (SHAMSI; KUMAR; DADA, 2008). Apesar de ser uma técnica sensível para detecção de fragmentação de DNA, a mesma requer treinamento e demanda muito tempo para sua execução, o que dificulta a avaliação de diversas amostras em um curto período de tempo. Neste trabalho, os resultados do ensaio Cometa mostraram que não houve diferença significativa entre os grupos experimentais em relação à fragmentação de DNA espermático.

Como dito anteriormente, os espermatozóides são células com DNA extremamente compactado, quando comparado com as células somáticas. Em estudos realizados em nossos laboratórios foi observado que os protocolos utilizados para avaliar a qualidade de cromatina espermática em humanos 
(Teste de dispersão de cromatina, Cometa alcalino) tiveram que ser modificados para a espécie bovina por causa da dificuldade em denaturar a cromatina. Estas modificações, nestes ensaios, sugerem que em bovinos, a compactação de DNA parece ser mais eficiente quando comparada com a mesma de outras espécies. Pode ser que esta característica da cromatina espermática da espécie bovina dificulte a visualização dos fragmentos de DNA pelo ensaio Cometa sugerindo que talvez este não seja o melhor teste para avaliar fragmentação de DNA espermático em bovinos.

Neste trabalho não foi observada correlação entre o SCSA e o ensaio Cometa. Pode ser que pelo fato do SCSA provocar um estresse ácido no DNA dos espermatozóides, este seja um teste mais eficiente na identificação de possíveis danos de cromatina que, devido ao fato do DNA espermático bovino estar muito compactado, o ensaio Cometa, nesta espécie, possa não conseguir detectar este dano com a mesma acurácia.

\subsection{ENSAIO TBARS}

O sêmen também foi avaliado quanto a susceptibilidade dos espermatozóides ao estresse oxidativo. As alterações seminais causadas pelo estresse oxidativo são ainda mais evidentes quando as células espermáticas são retiradas do plasma seminal que contém a única fonte de antioxidante para prevenir a formação excessiva de EROs (AITKEN et al., 2001). Os resultados do ensaio TBARS do presente estudo mostraram que não houve diferença significativa entre os grupos experimentais.

Apesar da ausência de diferenças entre os grupos experimentais, neste trabalho foi observada uma correlação positiva entre os ensaios de TBARS e SCSA, como descrito anteriormente. Por outro lado, não foi observada correlação entre o ensaio TBARS e a fragmentação de DNA espermático avaliado pelo ensaio Cometa. Este fato pode ter ocorrido devido a uma característica muito peculiar do malondialdeído (MDA). A peroxidação lipídica em espermatozóides promove um acúmulo progressivo de hidroperóxidos lipídicos na membrana plasmática destas células que posteriormente se 
decompõe e formam o MDA (NICHI, 2003). Segundo Voitkun e Zhitkovich (1999), o MDA tem a capacidade de reagir de forma covalente com o DNA formando múltiplos complexos. Desta forma, durante a eletroforese feita no ensaio Cometa, estes fragmentos de DNA ligados ao MDA migram pelo gel mais lentamente do que os fragmentos menores. Diante destas informações pode-se sugerir que as amostras de sêmen avaliadas neste estudo sejam mais susceptíveis ao estresse oxidativo e à fragmentação de DNA espermático e que a possível ligação entre o DNA e o MDA tenha mascarado os resultados do ensaio Cometa.

\subsection{PRODUÇÃO IN VITRO DE EMBRIÕES}

Os índices de clivagem e de blastocisto não apresentaram diferença significativa entre os grupos experimentais. Entretanto, as médias destas variáveis foram modestas. O índice de clivagem variou entre os grupos de $56,46 \%$ a $65,67 \%$, enquanto que a produção de blastocistos variou de $15,75 \%$ a $28,05 \%$. Houve uma correlação negativa tanto do índice de clivagem ( $r=-$ $0,417 ; p=0,009)$ quanto $o$ de blastocisto $(r=-0,367 ; p=0,023)$ com o ensaio TBARS. Este resultado sugere que quanto mais susceptíveis ao estresse oxidativo forem os espermatozóides, menores serão os índices de PIV de embriões. De acordo com Barros (2007), amostras de sêmen mais susceptíveis ao estresse oxidativo podem apresentar maior dano de mitocôndria, acrossomo e de membrana plasmática. Neste sentido, mesmo que não tenha existido a influência da fragmentação de DNA espermático na PIV de embriões, a mensuração da capacidade de resistir ao estresse oxidativo (i.e., TBARS) pôde avaliar com mais eficiência os danos em outras estruturas espermáticas que provalvemente diminuiram os índices de PIV de embriões.

Neste experimento foram utilizadas amostras de sêmen criopreservadas e, como dito anteriormente, o processo de congelação por si só, pode causar danos aos espermatozóides e aumentar o estresse oxidativo nestas células. A membrana plasmática é vulnerável às EROs por apresentar grande quantidade de PUFAs. Esta lesão de membrana pode prejudicar a reação acrossômica, a 
capacitação espermática e também a interação entre espermatozóide e oócito (NICHI, 2003), o que poderia justificar a diminuição dos índices de PIV, observados no presente estudo. Além disso, a lesão de membrana mitocondrial pode liberar fatores pró-oxidantes que atacam outras membranas como a acrossomal e a membrana plasmática da própria célula como também de células vizinhas (BARROS, 2007). Conseqüentemente, essa alteração também pode prejudicar a função espermática e consequentemente o processo de fecundação.

Apesar de não existir diferença significativa de núcleos positivos para TUNEL entre os grupos foi observada correlação positiva entre o ensaio TUNEL e o TBARS ( $r=0,417 ; p=0,009)$, ou seja, quanto mais susceptíveis forem os espermatozóides ao estresse oxidativo, maior a quantidade de núcleos marcados para apoptose. Sabe-se que umas das causas de apoptose durante o desenvolvimento embrionário é o aparecimento de anormalidades cromossômicas (FABIAN; KOPPEL; MADDOX-HYTTEL, 2005) e segundo Marnett (1999), o MDA pode ser considerado um fator mutagênico e carcinogênico. De acordo com estas informações, o estresse oxidativo pode ser uma das causas da diminuição do desenvolvimento embrionário, independente da existência da fragmentação de DNA espermático.

Por outro lado, sabe-se que as consequências da apoptose no desenvolvimento embrionário dependem da extensão das lesões (BRAD; HENDRICKS e HANSEN, 2007). De acordo com estes autores, o aumento de células apoptóticas é prejudicial ao desenvolvimento embrionário. Segundo Paula-Lopes e Hansen (2000), o estresse térmico é uma das causas de apoptose embrionária podendo afetar até 15-25\% dos blastômeros. Contudo, os autores ressaltam que este índice de apoptose não é necessariamente deletério ao embrião. Mesmo considerando que o estresse térmico não fazia parte do delineamento experimental do presente estudo, estes valores de apoptose embrionária descritos na literatura diferem das médias de células positivas para TUNEL observadas no presente estudo $(2,42 \%$ a $5,41 \%)$, o que pode explicar a não influência da apoptose no desenvolvimento embrionário, apresentado neste trabalho. 


\subsection{CONSIDERAÇÕES FINAIS}

Existem poucos estudos na literatura sobre fragmentação de DNA espermático na espécie bovina e respectiva influência no desenvolvimento embrionário. Neste presente trabalho, as amostras de sêmen avaliadas mostraram baixo índice de fragmentação de DNA espermático, quando comparado aos dados descritos na literatura para a espécie humana, por exemplo. É possível que a maior resistência dos espermatozóides bovinos à injúria juntamente com as condições ideais de manejo e genética destes animais confiram uma maior proteção ao material genético destas células. Como os resultados de fragmentação de DNA neste estudo não foram superiores a $12 \%$, pode ser que grande parte deste dano tenha sido reparado pelo oócito já que o gameta feminino tem a capacidade de reparar estes danos, permitindo o desenvolvimento embrionário normal.

Porém, ainda que este DNA tenha sido reparado é importante manter em mente que algumas informações genéticas podem ser transmitidas à prole de forma errada e que só serão identificadas em outras gerações (BARROS, 2007). Neste sentido, mais estudos sobre a integridade do material genético paterno devem ser realizados, principalmente em se tratando de uma espécie que apresenta uma grande quantidade de material genético armazenado em bancos de germoplasma.

Por outro lado, apesar dos danos de DNA não terem sido muito evidentes e não terem influenciado no desenvolvimento embrionário até o estádio de blastocisto, neste estudo foi observada a influência da susceptibilidade das células espermáticas ao estresse oxidativo na PIV de embriões. Talvez esta influência seja conseqüência do próprio processo de criopreservação do sêmen. No entanto, a problemática ainda está sem solução. Existem animais que possuem avaliação espermática compatível com os padrões aceitáveis para a espécie. Contudo, a fertilidade in vitro e, algumas vezes, até mesmo a in vivo, não condizem com estas avaliações. Neste estudo apostou-se nos altos índices de fragmentação do DNA espermático para explicar esse problema. No entanto, os resultados aqui apresentados demonstraram que a espécie bovina não apresenta altos índices de 
fragmentação como vistos em outras espécies, negando a hipótese de que na espécie bovina existe influência da qualidade da cromatina no desenvolvimento embrionário até o estádio de blastocisto.

Assim, surgem diversas dúvidas que ainda permanecem sem respostas: Para a espécie bovina, qual seria a real causa que faz com que não haja correlação entre a fertilidade e os parâmetros espermáticos utilizados de rotina? Qual o real papel da protamina nesta espécie? Como acontece o processo de protaminação? $O$ que 0 estresse oxidativo afeta no espermatozóide que leva à diminuição do desenvolvimento embrionário? Será que existem outras causas que afetem a qualidade da cromatina espermática na espécie bovina?

Para sanar estas dúvidas, mais pesquisas sobre fragmentação de DNA espermático devem ser realizadas. Talvez seja importante considerar nestes novos estudos que as lesões no material genético paterno possam ter consequências em longo prazo e não no período pré-implantacional do desenvolvimento embrionário. Sendo assim, as implicações do dano de cromatina espermática na espécie bovina continuam em pauta. 


\section{CONCLUSÕES}

Diante dos resultados apresentados conclui-se que o desenvolvimento embrionário in vitro não foi influenciado pela fragmentação de DNA espermático, contrariando a hipótese formulada. Entretanto, o desenvolvimento embrionário foi influenciado por espermatozóides mais susceptíveis ao estresse oxidativo. 


\section{REFERÊNCIAS}

AGARWAL, A.; SHYAM, S. R.; ALLAMANENI, M. D. Sperm DNA damage assessment: a test whose time has come. Fertility and sterility, v. 84, n. 4, p. 850-853, 2005.

AITKEN, R. J.; BUCKINGHAM, D.; WEST, K.; WU, F. C.; ZIKOPOULOS, K.; RICHARDSON, D. W. Differential contribution of leucocytes and spermatozoa to the generation of reactive oxygen species in the ejaculates of oligozoospermic patients and fertile donors. Journal of reproduction and fertility, v. 94, n. 2, p. 451-462, 1992.

AITKEN, R. J.; CLARKSON, J. S. Significance of reactive oxygen species and antioxidants in defining the efficacy of sperm preparation techniques. Journal of andrology, v. 9, n.6, p. 367-376, 1988.

AITKEN, R. J.; KRAUSZ, C. Oxidative stress, DNA damage and the $Y$ chromosome. Reproduction, v. 122, p. 497-506, 2001.

AHMADI, A.; NG, S. C. Fertilizing ability of DNA-damaged spermatozoa. The Journal of experimental zoology, v. 284, n. 6, p. 696-704, 1999.

ALLAMANENI, S. S.; AGARWAL, A.; NALLELLA, K. P.; SHARMA, R. K.; THOMAS Jr., A. J.; SIKKA, S. C. Characterization of oxidative stress status by evaluation of reactive oxygen species levels in whole semen and isolated spermatozoa. Fertility and sterility, v. 83, n. 3, p. 800-803, 2005.

ALOMAR, M.; MAHIEU, J.; VERHAEGHE, B.; DEFOIN, L.; DONNAY, I. Assessment of sperm quality parameters of six bulls showing different abilities to promote embryo development in vitro. Reproduction, fertility, and development, v. 18, n. 3, p. 395-402, 2006.

AMANN, R. P. Endocrine changes associated with onset of spermatogenesis in Holstein bulls. Journal of dairy science, v. 66, n. 12, p. 2606-2622, 1983.

AMIRAT, L.; ANTON, M.; TAINTURIER, D.; CHATAGNON, G.; BATTUT, I.; COURTENS, J. L. Modifications of bull spermatozoa induced by three extenders: Biociphos, low density lipoprotein and Triladyl, before, during and after freezing and thawing. Reproduction, v. 129, n. 4, p. 535-543, 2005. 
ANDRABI, S. M. H. Mammalian sperm chromatin structure and assessment of DNA fragmentation. Journal of assisted reproduction and genetics, v. 24, n. 12, p. 561-569, 2007.

AOKI, V. W.; LIU, L.; CARRELL, D. T. Identification and evaluation of a novel sperm protamine abnormality in a population of infertile males. Human reproduction, v. 20, n. 5, p.1298-1306, 2005.

BALHORN, R. A model for the structure of chromatin in mammalian sperm. The Journal of cell biology, v. 93, n. 2, p. 298-305, 1982.

BARROS, P. M. H. Estresse oxidativo e integridade de DNA em sêmen resfriado de gato-do-mato-pequeno (Leopardus tigrinus, SCHREBER, 1775). 2007. 120f. Tese (Doutorado emCiências). Faculdade de Medicina Veterinária e Zootecnia, Universidade de São Paulo, São Paulo, 2007.

BARROSO, G.; VALDESPIN, C.; VEGA, E.; KERSHENOVICH, R.; AVILA, R.; AVENDAÑO, C.; OEHNINGER, S. Developmental sperm contributions: fertilization and beyond. Fertility and sterility, v. 92, n. 3, p. 835-848, 2009.

BAUM, J. S.; St. GEORGE, J. P.; McCALL, K. Programmed cell death in the germline. Seminars in cell \& developmental biology, v. 16, n. 2, p. 245-259, 2005.

BETTS, D. H.; KING, W. A. Genetic regulation of embryo death and senescensce. Theriogenology, v. 55, n. 1, p. 171-191, 2001.

BIANCHI, P. G.; MANICARDI, G. C.; BIZZARO, D.; BIANCHI, U.; SAKKAS, D. Effect of deoxyribonucleic acid protamination on fluorochrome staining and in situ nick-translation of murine and human mature spermatozoa. Biology Reproduction, v. 49, n. 5, p. 1083-1088, 1993.

BIZZARO, D.; MANICARDI, G. C.; BIANCHI, P. G.; BIANCHI, U.; MARIETHOZ, E.; SAKKAS, D. In-situ competition between protamine and fluorochromes for sperm DNA. Molecular human reproduction, v. 4, n. 2, p. 127-132, 1998.

BLUMER, C. G.; FARINELLO, R. M.; RESTELLI, A. E.; SPAINE, D. M.; BERTOLLA, R. P.; CEDENHO, A. P. Sperm nuclear DNA fragmentation and mitochondrial activity in men with varicocele. Fertility and sterility, v. 90, n. 5, p. 1716-1722, 2007. 
BOCHENEK, M.; SMORAG, Z.; PILCH, J. Sperm chromatin structure assay of bulls qualified for artificial insemination. Theriogenology, v. 56, n. 4, p. 557567, 2001.

BOE-HANSEN, G. B.; AVERZ, B.; CHRISTENSEN, P.; LEHN-JENSEN, H.; GREVE, T. Sperm chromatin structure and IVF in bull with low fertilization in vivo. Theriogenology, v. 59, n. 1, p. 439, 2003.

BRAD, A. M.; HENDRICKS, K. E. M.; HANSEN, P. J. The block to apoptosis in bovine two-cell embryos involves inhibition of caspase- 9 activation and caspase-mediated DNA damage. Reproduction, v. 134, n. 6, p. 789-797, 2007.

BRINKWORTH, M. H. Paternal transmission of genetic damage: findings in animals and humans. International Journal of Andrology, v. 23, p. 123-135, 2000.

BRITO, L. F. C.; BARTH, A. D.; BILODEAU-GOESEELS, S.; PANICH, P. L.; KASTELIC, J. P. Comparison of methods to evaluate the plasmalemma of bovine sperm and their relationship with in vitro fertilization rate.

Theriogenology, v. 60, n. 8, p. 1539-1551, 2003.

CARRELL, D. T.; EMERY, B. R.; HAMMOUD, S. Altered protamine expression and diminished spermatogenesis: what is the link? Human reproduction update, v. 13, n. 3, p. 1-15, 2007.

CARRELL, D. T.; LIU, L. Altered protamine 2 expression is uncommon in donors of known fertility, but common among men with poor fertilizing capacity, and may reflect other abnormalities of spermiogenesis. Journal of andrology, v. 22, n. 4 , p. $604-610,2001$

COMIZZOLI, P.; MARQUANT-LE GUIENNE, B.; HEYMAN, Y.; RENARD, J. P. Onset of the first $\mathrm{S}$-phase is determined by a paternal effect during the G1phase in bovine zygotes. Biology of Reproduction, v. 62, n. 6, p. 1677-1684, 2000.

DERIJCK, A.; VAN DER HEIJDEN, G.; GIELE, M.; PHILIPPENS, M.; DE BOER, P. DNA double-strand break repair in paternal chromatin of mouse zygotes, the first cell cycle as an origin of de novo mutation. Human molecular genetics, v. 17, n. 13, p. 1922-1937, 2008. 
DONNELLY, E. T.; O'CONNELL, M.; MCCLURE, N.; LEWIS, S. E. M. Differences in nuclear DNA fragmentation and mitochondrial integrity of semen and prepared human spermatozoa. Human Reproduction, v. 15, n. 7, p. 1552$1561,2000$.

EID, L. N.; LORTON, S. P.; PARRISH, J. J. Paternal influence on S-Phase in the first cell cycle of bovine embryo. Biology of Reproduction, v. 51, n. 6, p. 1232-1237, 1994.

ENCISO, M.; LÓPEZ-FERNÁNDEZ, C.; FERNÁNDEZ, J. L.; GARCÍA, P.; GOSÁLBEZ, A.; GOSÁLVEZ, J. A new method to analyze boar sperm DNA fragmentation under bright-field or fluorescence microscopy. Theriogenology, v. 65 , n. 2 , p. $308-316,2006$.

ERENPREISS, J.; SPANO, M.; ERENPREISA, J.; BUNGUM, M.; GIWERCMAN, A. Sperm chromatin structure and male fertility: biological and clinical aspects. Asian journal of andrology, v. 8, n. 1, p. 11-29, 2006.

ESTERHUIZEN, A. D.; FRANKEN, D. R.; LOURENS, J. G. H.; PRINSLOO, E.; ROOYEN L. H. Sperm chromatin packaging as an indicationr of in-vitro fertilization rates. Human Reproduction, v. 15, n. 3, p. 657-661, 2000.

EVENSON, D. P.; LARSON, K. L.; JOST, L. K. Sperm chromatin structure assay: its clinical use for detecting sperm DNA fragmentation in male infertility and comparisons with other techniques. Journal of andrology, v. 23, n. 1, p. 25-43, 2002.

FABIAN, D.; KOPPEL, J.; MADDOX-HYTTEL, P. Apoptotic processes during mammalian preimplantation development. Theriogenology, v. 64, n. 2, p. 221231, 2005.

FATEHI, A. N.; BEVERS, M. M.; SCHOEVERS, E.; ROELEN, B. A. J.; COLENBRANDER, B.; GADELLA, B. M. DNA damage in bovine sperm does not block fertilization and early embryonic development but induces apoptosis after the first cleavages. Journal of Andrology, v. 27, n. 2, p. 176-188, 2006.

FERNÁNDEZ, J. L.; MURIEL, L.; RIVERO, M. T.; GOYANES, V.; VAZQUEZ, R.; ALVAREZ, J. G. The sperm chromatin dispersion test: a simple method for the determination of sperm DNA fragmentation. Journal of Andrology, v. 24, n. 1, p. 59-66, 2003. 
FOOTE, R. H. The history of artificial insemination: Selected notes and notables. Journal of animal science, v. 80, n.1, p. 1-10, 2002.

FRANCAVILLA, S.; D'ABRIZIO, P.; RUCCI, N.; SILVANO, G.; PROPERZI, G.; STRAFACE, E.; CORDESCHI, G.; NECOZIONE, S.; GNESSI, L.; ARIZZI, M.; ULISSE, S. Fas and Fas ligand expression in fetal and adult human testis with normal with normal or deranged spermatogenesis. The Journal of clinical endocrinology and metabolism, v. 85, n. 8, p. 2692-2700, 2000.

GJORRET, J. O.; KNIJN, H. M.; DIELEMAN, S. J.; AVERY, B.; LARSSON, L. I.; MADDOX-HYTTEL, P. Chronology of apoptosis in bovine embryos produced in vivo and in vitro. Biology of reproduction, v. 69, n. 4, p. 1193-1200, 2003.

HENDRICKS, K. E. M.; MARTINS, L.; HANSEN, P. J. Consequences for the bovine embryo of being derived from a spermatozoon subjected to postejaculatory aging and heat shock: development to blastocyst stage and sex ratio. The Journal of reproduction and development, v. 55, n. 1, p. 69-74, 2009.

HENKEL, R.; HAJIMOHAMMAD, M.; STALF, T.; HOOGENDIJK, C.; MEHNERT, C.; MENKVELD, R.; GIPS, H.; SCHILL, W. B.; KRUGER, T. F. Influence of deoxyribonucleic acid damage on fertilization and pregnancy. Fertility and sterility, v. 81, n. 4, p. 965-972, 2004.

JANUSKAUSKAS, A.; JOHANNISSON, A.; RODRIGUEZ-MARTINEZ, H. Assessment of sperm characteristics post-thaw and response to calcium ionophore in relation to fertility in Swedish dairy Al bulls. Theriogenology, $v$. 53, n. 4, p. 859-875, 2000.

SHAMAN, J. A.; WARD, W. S. Sperm DNA stability. In: De JONGE, C.; BARRATT, C. The Sperm Cell: Production, Maturation, Fertilization, Regeneration. Inglaterra: Cambridge, 2006. p. 31-48.

KAUFMANN, S. H.; HENGARTNER, M. O. Programmed cell death: alive and well in the new millennium. Trends in cell biology, v. 11, n. 12, p. 526-534, 2001.

KHURANA, N. K.; NIEMANN, H. Effects of oocyte quality, oxygen tension, embryo density, cummulus cells and energy substrates on cleavage and morula/blastocyst formation of bovine embryos. Theriogenology, v. 54, n. 5, p. 741-756, 2000. 
LEWIS, S. E.; AGBAJE, I. M. Using the alkaline comet assay in prognostic test for male infertility and assisted reproductive technology outcome. Mutagenesis, v. 23, n. 3, p. 163-170, 2008.

MAIER, W. M.; NUSSBAUM, G.; DOMENJOUD, L.; KLEMM, U.; ENGEL, W. The lack of protamine $2(P 2)$ in boar and bull spermatozoa is due to mutations within the P2 gene. Nuclei Acid Research, v. 18, n. 5, p. 1249-1254, 1990.

MAKKER, K.; AGARWAL, A.; SHARMA, R. Oxidative stress \& male infertility. The Indian journal of medical research, v. 129, n. 4, p. 357-367, 2009.

MARNETT, L. J. Lipid peroxidation - DNA damage by malondialdehyde. Mutation Research, v. 424, n. 1-2,p. 83-95 1999.

MCLAY, D. W.; CLARKE, H. J. Remodelling the paternal chromatin at fertilization in mammals. Reproduction, v. 125, n. 5, p. 625-633, 2003.

MCPHERSON, S. M.; LONGO, F. J. Localization of DNase I-Hypersensitive regions during rats spermatogenesis: stage-dependent patterns and unique sensitivity of elongating spermatids. Molecular reproduction and development, v. 31, n. 4, p. 268-279, 1992.

NANASSY, L.; CARRELL, D. T. Paternal effects on early embriogenesis. Journal of experimental \& clinical assisted reproduction, v. 5, n.1, p. 2 2008

NASR-ESFAHANI, M. H.; RAZAVI, S.; MOZDARANI, H.; MARDANI, M.; AZVAGI, H. Relationship between protamine deficiency with fertilization rate and incidence of sperm premature chromosomal condensation post-ICSI. Andrologia, v. 36, n. 3, p. 95-100, 2004.

NICHI, M. Sistemas de proteção enzimática e níveis de peroxidação espontânea de lipídios seminais de touros zebuínos e taurinos criados a campo na região de Dourados, MS. 2003. 101f. Dissertação (Mestrado em Medicina Veterinária) - Faculdade de Medicina Veterinária e Zootecnia, Universidade de São Paulo, São Paulo, 2003.

$\mathrm{NICHI}, \mathrm{M}$. Efeito do tratamento com antioxidantes e ácidos graxos poliinsaturados em amostras espermáticas epididimárias de touros. 2009. 120 f. Tese (Doutorado em Ciências) - Faculdade de Medicina Veterinária e Zootecnia, Universidade de São Paulo, São Paulo, 2009. 
NICHI, M.; BOLS, P. E. J.; ZUGE, R. M.; BARNABE, V. H.; GOOVAERTS, I. G. F.; BARNABE, R. C.; CORTADA, C. N. M. Seasonal variation in semen quality of Bos indicus and Bos Taurus bulls raised under tropical conditions.

Theriogenology, v. 66, n. 4, p. 822-828, 2006.

OLIVA, R. Protamines and male fertility. Human reproduction update, v. 12, n. 4, p. 417-435, 2006.

PALMA, G. A.; SINOWATZ, F. Male and female effects on in the in vitro production of bovine embryos. Anatomia, histologia, embryologia, v. 33, n. 5, p. 257-262, 2004.

PARRISH, J. J.; KROGENAES, A.; SUSKO-PARRISH, J. L. Effect of bovine sperm separation by either swim-up or percoll method on success of in vitro fertilization and early embryonic development. Theriogenology, v. 44, n. 6, p. 859-69, 1995.

PARRISH, J. J.; SUSKO-PARRISH, J. L.; WINER, M. A.; FIRST, N. L.; Capacitation of bovine sperm by heparin. Biology of reproduction, v. 38, n. 1, p. 1171-1180, 1988.

PASQUALOTTO, F. F.; HALLAK, J.; PAGANI, R. L. Avanços na investigação do homem infértil - Testes de função espermática. In: WROCLAWSKI, E. R.; BORGES JR, E. II Consenso Brasileiro de Infertilidade Masculina. São Paulo: Casa de Tipos Bureau e Editora, 2003. p. 32-40.

PAULA-LOPES, F. F.; HANSEN, P. J. Heat-shock induced apoptosis in preimplantation bovine embryos is a developmentally-regulated phenomenon. Biology of reproduction, v. 66, n. 4 , p. 169-177, 2002.

PAULA-LOPES, F. F.; JOUSAN, F. D.; ROTH, Z.; SOTO, P.; HANSEN, P. J. TUNEL procedure in bovine embryo. 2003. Disponível em: <http://www.animal.ufl.edu/hansen/protocols/tunel.htm>. Acesso em: 10 nov. 2009.

PEREIRA, R. J. T. A.; TULI, R. K.; WALLENHORST, S.; HOLTZ, W. The effect of heparin, caffeine and calcium ionophore A23187 in frozen-thawed bovine and caprine spermatozoa. Theriogenology, v. 54, n. 2, 185-192, 2000. 
PERREAULT, S. D. Distinguishing between fertilization failure and early pregnancy loss when identifying male-mediated adverse pregnancy outcome.

Advances in Experimental Medicine and Biology, v. 518, p. 189-198, 2003.

RAFF, M. Cell suicide for beginners. Nature, v. 396, n. 6707, p. 119-122, 1998.

RECKOVA, Z.; MACHATKOVA, M.; RYBAR, R.; HORAKOVA, J.; HULINSKA, P.; MACHAL, L. Evaluation of chromatin integrity of motile bovine spermatozoa capacitated in vitro. Zygote, v. 16, n. 3, p. 195-202, 2008.

ROCHA, H. L. O. G.; BELETTI, M. E.; MARCOLINI, T. T.; AMORIM, D. A. Z. Uso de laranja de acridina e azul de toluidina na avaliação da fertilidade masculina. Journal of biosciences, v.18, n. 1, p. 65-77, 2002.

RODRIGUEZ, I.; ODY, C.; ARAKI, K.; GARCIA, I.; VASSALLI, P. An early and massive wave of germinal cell apoptosis is required for the development of functional spermatogenesis. The EMBO journal, v. 16, n. 9, p. 2262-2270, 1997.

RODRÍGUEZ-MARTINEZ, H. State of the art in farm animal sperm evaluation. Reproduction, Fertility and Development, v. 19, n.1, p. 91-101, 2007

RODRIGUEZ-MARTINEZ, H.; BARTH, A. D. In vitro evaluation of sperm quality related to in vivo function and fertility. Soc Reprod Fertil Suppl, v. 64, n.1, p. 39-54, 2002.

RUSSEL, L. D.; CHIARINI-GARCIA, H.; KORSMEYER, S. J.; KNUDSON, M. Bax-dependent spermatogonia apoptosis is required for testicular development and spermatogenesis. Biology of Reproduction, v. 66, n. 4, p. 950-958, 2002.

SAKKAS, D.; MARIETHOZ, E.; MANICARDI, G.; BIZZARO, D.; BIANCHI, P. G.; BIANCHI, U. Origin of DNA damage in ejaculated human spermatozoa. Reviews of reproduction, v. 4, n. 1, p. 31-37, 1999.

SAKKAS, D.; MOFFATT, O.; MANICARDI, G. C.; MARIETHOZ, E.; TAROZZI, $\mathrm{N}$.; BIZZARO, D. Nature of DNA damage in ejaculated human spermatozoa and the possible involvement of apoptosis. Biology of Reproduction, v. 66, n. 4, p. 1061-1067, 2002.

SAS. The Statistical Analyze Systems for Windows V8. Cary, 1999-2001. 
SELI, E.; GARDNER, D. K.; SCHOOLCRAFT, W. B.; MOFFATT, O.; SAKKAS, $D$. Extent of nuclear DNA damage in ejaculated spermatozoa impacts on blastocyst development after in vitro fertilization. Fertility and sterility, v. 82, n. 2, p. 378-383, 2004.

SHAMSI, M. B.; KUMAR, R.; DADA, R. Evaluation of nuclear DNA damage in human spermatozoa in men of opting for assisted reproduction. The Indian journal of medical research, v. 127, n. 2, p. 115-123, 2008.

SIMÕES, R.; FEITOSA, W. B.; MENDES, C. M.; MARQUES, M. G.; NICACIO, A. C.; de BARROS, F. R. O.; VISINTIN, J. A.; ASSUMPÇÃO, M. E. O. A. Use of chromomycin A3 staining in bovine sperm cells for detection of protamine deficiency. Biotechnic \& histochemistry, v. 84, n. 3, p. 79-83, 2009.

SINGH, N. P.; MULLER, C. H.; BERGER, R. E. Effect of age on DNA doublestrand breaks and apoptosis in human sperm. Fertility and sterility, v. 80, n. 6 , p. 1420-1430, 2003.

SREENAN, J. M.; DISKIN, M. G. Early embryonic mortality in the cow: its relationship with progesterone concentration. The Veterinary record, v. 112, n. 22, p. 517-521, 1983.

SUGANUMA, R.; YANAGIMACHI, R.; MEISTRICH, M. L. Decline in fertility of mouse sperm with abnormal chromatin during epididymal passage as revealed by ICSI. Human Reproduction, v. 20, n. 11, p. 3101-3108, 2005.

TAMASSIA, M.; HEYMAN, Y.; LAVERGNE, Y.; RICHARD, C.; GELIN, V.; RENARD, J. P.; CHASTANT-MAILLARD, S. Evidence of oocyte donor cow effect over oocyte production and embryo development in vitro. Reproduction, v. 126 , n. 5, p. 629-637, 2003.

TAROZZI, N.; BIZZARO, D.; FLAMIGNI, C.; BORINI, A. Clinical relevance of sperm DNA damage in assisted reproduction. Reproductive biomedicine online, v. 14, n. 6, p. 746-757, 2007.

TARTAGLIONE, C. M.; RITTA, M. N. Prognostic value of spermatological parameters as predictors of in vitro fertility of frozen-thawed bull semen. Theriogenology, v. 62, n. 7, p.1245-1252, 2004.

TESARIK, J. Paternal effects on cell division in the human preimplantation embryo. Reproductive biomedicine online, v. 10, n. 3, p. 370-375, 2005. 
TESARIK, J.; GRECO, E.; MENDONZA, C. Late, but not early, paternal effect on human embryo development is related to sperm DNA fragmentation. Human Reproduction, v. 19, n. 3, p. 611-615, 2004.

TESARIK, J.; MENDONZA, C.; GRECO, E. Paternal effects acting during the first cell cycle of human preimplantation development after ICSI. Human Reproduction, v. 17, n. 1, p. 184-189, 2002.

URREGO, R.; RIOS, A.; ÁNGEL, M. O.; CAMARGO, O. Efecto de la centrifugación sobre la membrana plasmática y el ADN de espermatozoides bovinos. Revista Colombiana de Ciencias Pecuarias, v. 21, n. 1, p. 19-26, 2008.

VIRRO, M. R.; LARSON-COOK, K. L.; EVENSON, D. P. Sperm chromatin structure assay (SCSA) parameters are related to fertilization, blastocyst development, and ongoing pregnancy in in vitro fertilization and intracytoplasmic sperm injection cycles. Fertility and Sterility, v. 81, n. 5, p. 1289-1295, 2004.

VOITKUN, V.; ZHITKOVICH, A. Analysis of DNA-protein crosslinking activity of malondialdehyde in vitro. Mutation research, v. 424, n. 1-2, p. 97-106, 1999.

WARD, F.; RIZOS, D.; CORRIDAN, D.; QUINN, K.; BOLAND, M.; LONERGAN, $P$. Paternal influence on the time of first embryonic cleavage post insemination and the implications for subsequent bovine embryo development in vitro and fertility in vivo. Molecular Reproduction and development, v. 60, n. 1, p. 47$55,2001$.

WOLFF, $\mathrm{H}$. The biologic significance of whit blood cells in semen. Fertility and Sterility, v. 63, n. 6, p. 1143-1157, 1995.

WOUTERS-TYROU, D.; MARTINAGE, A.; CHEVAILLIER, P.; SAUTIĖRE, P. Nuclear basic proteins in spermiogenesis. Biochimie, v.80, n. 2, p.117-128, 1998.

YIN, Y.; STAHL, B. C.; DEWOLF, W. C.; MORGENTALER, A. p53-mediated germ cell quality control in spermatogenesis. Developmental biology, v. 204, n. 1, p. 165-171, 1998. 
APÊNDICE A - Padronização da técnica de Estrutura de Cromatina Espermática (SCSA) para o citômetro de fluxo Guava EasyCyte $^{\circledR}$ (Guava Technologies, Hayward, CA, E.U.A)

O teste de SCSA foi realizado de acordo com o protocolo descrito por Evenson et al. (2002), com pequenas alterações. O SCSA foi utilizado para avaliar a compactação do DNA espermático pela avaliação da susceptibilidade do DNA à denaturação ácida in situ. A propriedade metacromática da laranja de acridina (LA - Sigma ${ }^{\circledR}$, St. Louis, MO, E.U.A) é usada para distinguir entre o DNA íntegro (fita dupla) e o lesado (fita simples). Quando a LA se intercala com o DNA íntegro, ela fluoresce em verde e quando se liga ao DNA lesado, a LA fluoresce em vermelho.

As análises foram feitas utilizando o programa FlowJo v8.7 (Flow Cytometry Analysis Software - Tree Star Inc., Ashland, Oregon, USA), com o qual se calculou o AlfaT, que quantifica a extensão da denaturação do DNA de cada espermatozóide da amostra. O AlfaT é definido como o resultado da divisão da fluorescência vermelha pela fluorescência total $[\alpha T=$ vermelho/(vermelho + verde)]. As células fora da população principal (COMPaT, cell outside the mains population) são marcadas visualmente a partir do histograma de $\alpha \mathrm{T}$ e representa a porcentagem de DNA denaturado na amostra.

Foi utilizada uma amostra de sêmen de um animal aleatório. Uma alíquota $(250 \mu \mathrm{l})$ da amostra foi submetida à fragmentação de DNA utilizando $500 \mu$ l de peróxido de hidrogênio $30 \%\left(\mathrm{H}_{2} \mathrm{O}_{2}\right)$. As células foram incubadas por 2 horas e depois lavadas duas vezes por centrifugação em PBS (600g/5 minutos) e a concentração ajustada para 1-5 milhões de espermatozóides/ml.

Após as lavagens para remoção do peróxido de hidrogênio foi realizada a coloração com L.A adaptada a partir do protocolo descrito por Boe-Hansen et al. (2005). Resumidamente, as células espermáticas (1-5 milhões $/ \mathrm{ml}$ ) foram colocadas em $100 \mu$ le tampão TNE acrescido de $200 \mu l$ de detergente ácido. Após 30 segundos foi acrescentada a L.A $(600 \mu l)$ e avaliado por citometria de fluxo (excitação de $488 \mathrm{~nm}$ e $15 \mathrm{~mW}$ ) após 3-5 minutos. Foram avaliadas: a) amostra não fragmentada (0\%); b) amostra fragmentada (100\%); c) amostra a 
+ b (50\%). Foram avaliadas 10.000 células em cada amostra de sêmen de cada animal (Figura 12).
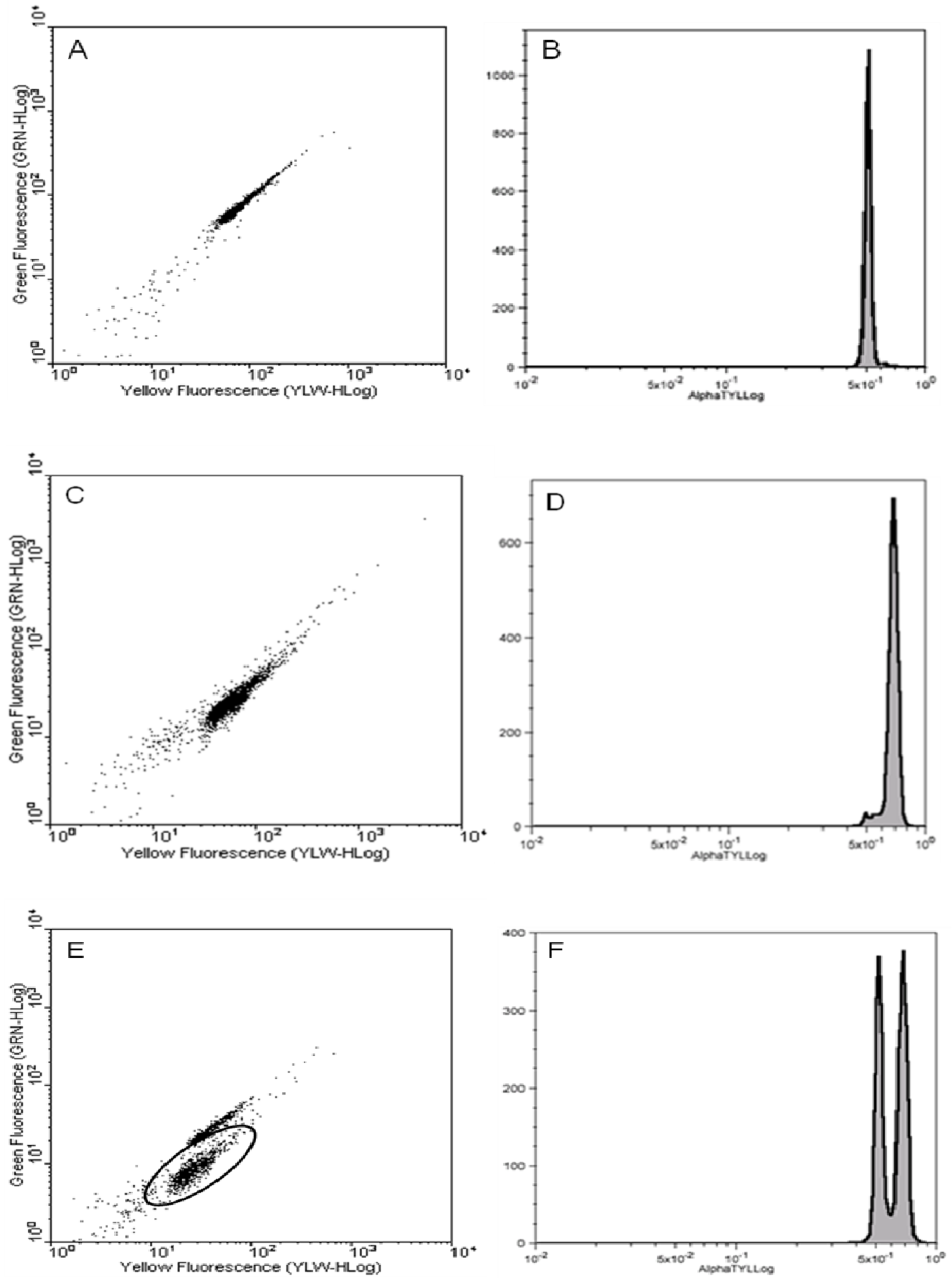

Figura 4 - Exemplos de gráficos gerados pelo teste SCSA. Gráficos B, D e F - histogramas correspondentes de aT. Gráficos A e B - espermatozóides com cromatina normal; Gráficos C e D - espermatozóides com DNA fragmentado; Gráficos E e $\mathrm{F}$ - população com $50 \%$ dos espermatozóides com DNA fragmentado, na qual as células com fragmentação de DNA. 
Anexos 
ANEXO A - Meios para maturação in vitro - MIV

- Meio de lavagem MIV (Pré-MIV)

\begin{tabular}{c|c|c|c}
\hline Reagente & Fabricante & Catálogo & Volume \\
\hline M-199 com HEPES & Gibco & $12380-028$ & $9 \mathrm{ml}$ \\
\hline Soro Fetal Bovino 10\% & Gibco & $16140-014$ & $1 \mathrm{ml}$ \\
\hline Pyruvato 0,2mM & Sigma & P-4562 & $20 \mu \mathrm{l}$ \\
\hline Gentamicina $50 \mu \mathrm{g} / \mathrm{ml}$ & Sigma & G-1264 & $50 \mu \mathrm{l}$ \\
\hline
\end{tabular}

Filtrar em $0,22 \mu \mathrm{m}$

- Meio de maturação in vitro

\begin{tabular}{|c|c|c|c|}
\hline Reagente & Fabricante & Catálogo & Volume \\
\hline M-199 com BICARBONATO & Gibco & $11150-026$ & $9 \mathrm{ml}$ \\
\hline Soro Fetal Bovino 10\% & Gibco & $16140-014$ & $1 \mathrm{ml}$ \\
\hline Piruvato $0,2 \mathrm{mM}$ & Sigma & P-4562 & $20 \mu \mathrm{l}$ \\
\hline Gentamicina $50 \mu \mathrm{g} / \mathrm{ml}$ & Sigma & G-1264 & $50 \mu \mathrm{l}$ \\
\hline $\mathrm{FSH} 0,5 \mu \mathrm{g} / \mathrm{ml}$ & Bioniche & Folltropin-V & $10 \mu \mathrm{l}$ \\
\hline hCG $7 U \mathrm{Ul} / \mathrm{ml}$ & Intervet & Chorulon & $100 \mu \mathrm{l}$ \\
\hline \multicolumn{4}{|c|}{$0,22 \mu \mathrm{m}$} \\
\hline Estradiol $1 \mu \mathrm{g} / \mathrm{ml}$ & Sigma & $E-4389$ & $10 \mu \mathrm{l}$ \\
\hline
\end{tabular}


ANEXO B - Soluções estoques e meio para FIV

- Soluções estoque para FIV (Parrish et al., 1988)

\begin{tabular}{|c|c|c|c|c|}
\hline Reagente & Fabricante & Catálogo & $\begin{array}{c}\text { TALP } \\
\text { STOCK }(50 \mathrm{ml})\end{array}$ & $\begin{array}{c}\text { TALP } \\
\text { SÊMEN }(50 \mathrm{ml})\end{array}$ \\
\hline $\mathrm{NaCl}$ & Sigma & S-5886 & $0,3330 \mathrm{~g}$ & $0,2910 \mathrm{~g}$ \\
\hline $\mathrm{KCl}$ & Sigma & P-5405 & $0,0120 \mathrm{~g}$ & $0,0115 g$ \\
\hline $\mathrm{MgCl}_{2}$ & Sigma & M-2393 & $0,0050 \mathrm{~g}$ & $0,0040 \mathrm{~g}$ \\
\hline $\mathrm{NaH}_{2} \mathrm{PO}_{4}$ & Sigma & S-0876 & $0,00205 \mathrm{~g}$ & $0,00175 \mathrm{~g}$ \\
\hline $\mathrm{NaHCO}_{3}$ & Sigma & S-8875 & $0,1050 \mathrm{~g}$ & $0,1050 \mathrm{~g}$ \\
\hline $\mathrm{CaCl}_{2} \mathrm{H}_{2} \mathrm{O}$ & Sigma & C-5670 & $0,0150 \mathrm{~g}$ & $0,015 \mathrm{~g}$ \\
\hline Ác.Lactico syr. & Sigma & L-7900 & $71,5 \mu \mathrm{l}$ & $155 \mu \mathrm{l}$ \\
\hline Hepes & Sigma & $\mathrm{H}-0891$ & $\star * \star * \star * \star * * * * *$ & $0,1190 \mathrm{~g}$ \\
\hline \multicolumn{2}{|c|}{$\mathrm{pH}=7,4$} & & & $O S M=295-300$ \\
\hline
\end{tabular}

Filtrar em $0,22 \mu \mathrm{m}$

- Solução de Gentamicina

\begin{tabular}{c|c|c|c}
\hline Reagentes & Fabricante & Catálogo & 100ml \\
\hline Sulfato de Gentamicina & Sigma & G-1264 & $50 \mathrm{mg}$ \\
\hline Solução fisiológica & & & $100 \mathrm{ml}$ \\
\hline
\end{tabular}

Aliquotar e manter a $-20^{\circ} \mathrm{C}$.

- Solução de Piruvato

\begin{tabular}{c|c|c|c}
\hline Reagentes & Fabricante & Catálogo & 10ml \\
\hline Ácido Pirúvico & Sigma & P-3662 & $22 \mathrm{mg}$ \\
\hline Água Destilada & & & $10 \mathrm{ml}$ \\
\hline
\end{tabular}

Aliquotar e manter a $-20^{\circ} \mathrm{C}$.

- Solução pH 4.0

\begin{tabular}{c|c|c|c}
\hline Reagente & Fabricante & Catálogo & 50ml \\
\hline Na Lactato & Sigma & L-7900 & $165 \mathrm{mg}$ \\
\hline Na metabisulfito & Sigma & S-1516 & $0,050 \mathrm{~g}$ \\
\hline Água Milli-Q (q.s.p) & & & $50 \mathrm{ml}$ \\
\hline
\end{tabular}

$$
\mathrm{pH}=4,0
$$


- Componentes da solução PHE

\begin{tabular}{c|c|c|c}
\hline Reagente & Fabricante & Catálogo & \\
\hline Penicilamina $2 \mu \mathrm{M}$ & Sigma & P-40-3 & $3 \mathrm{mg} / 10 \mathrm{ml}$ salina $0,9 \%$ \\
\hline Hipotaurina $1 \mu \mathrm{M}$ & Sigma & $\mathrm{H}-1384$ & $1,09 \mathrm{mg} / 10 \mathrm{ml}$ salina $0,9 \%$ \\
\hline Epinefrina $0,25 \mu \mathrm{M}$ & Sigma & $21,930-4$ & $1,83 \mathrm{mg} / 40 \mathrm{ml}$ sol. $\mathrm{pH} 4,0$ \\
\hline
\end{tabular}

- Solução PHE

\begin{tabular}{c|c|c|c}
\hline Reagente & Fabricante & Catálogo & Volume \\
\hline Penicilamina & Sigma & $\mathrm{P}-40-3$ & $2,5 \mathrm{ml}$ \\
\hline Hipotaurina & Sigma & $\mathrm{H}-1384$ & $2,5 \mathrm{ml}$ \\
\hline Epinefrina & Sigma & $21,930-4$ & $2 \mathrm{ml}$ \\
\hline Solução salina $0,9 \%$ & & & $4 \mathrm{ml}$ \\
\hline
\end{tabular}

- Meio de lavagem FIV (Pré-FIV)

\begin{tabular}{c|c|c|c}
\hline Reagente & Fabricante & Catálogo & Volume \\
\hline M-199 com HEPES & Gibco & $12380-028$ & $10 \mathrm{ml}$ \\
\hline BSA - V & Sigma & A-9647 & $0,030 \mathrm{~g}$ \\
\hline Piruvato 0,2mM & Sigma & P-4562 & $20 \mu \mathrm{l}$ \\
\hline Gentamicina $50 \mu \mathrm{g} / \mathrm{ml}$ & Sigma & G-1264 & $50 \mu \mathrm{l}$ \\
\hline
\end{tabular}

Filtrar em 0,22 $\mu \mathrm{m}$

- Meio FIV

\begin{tabular}{c|c|c|c}
\hline Reagente & Fabricante & Catálogo & 10ml \\
\hline TL - Stock & & & $10 \mathrm{ml}$ \\
\hline BSA - Livre de Ácidos Graxos & Sigma & A-7511 & $0,060 \mathrm{~g}$ \\
\hline Piruvato 0,2mM & Sigma & P-4562 & $20 \mu \mathrm{l}$ \\
\hline Gentamicina $50 \mu \mathrm{g} / \mathrm{ml}$ & Sigma & G-1264 & $50 \mu \mathrm{l}$ \\
\hline
\end{tabular}

Filtrar em $0,22 \mu \mathrm{m}$

- Meio FIV gotas

\begin{tabular}{c|c|c|c}
\hline Reagente & Fabricante & Catálogo & 4ml \\
\hline Meio - FIV & & & $3.640 \mathrm{ml}$ \\
\hline Heparina 140usp/mg & Sigma & $\mathrm{H}-9399$ & $40 \mu \mathrm{l}$ \\
\hline PHE & & & $160 \mu \mathrm{l}$ \\
\hline
\end{tabular}

Filtrar em 0,22 $\mu \mathrm{m}$ 
ANEXO C - Meio para cultivo (SOFaa)

- Solução SOFaa estoque

\begin{tabular}{c|c|c|c}
\hline Reagentes & Fabricante & Catálogo & $\mathbf{1 0 0 m l}$ \\
\hline $\mathrm{NaCl}$ & Sigma & S-5886 & $0,6294 \mathrm{~g}$ \\
\hline $\mathrm{KCl}$ & Sigma & P-5405 & $0,0534 \mathrm{~g}$ \\
\hline $\mathrm{KH}_{2} \mathrm{PO}_{4}$ & Sigma & P-5655 & $0,0162 \mathrm{~g}$ \\
\hline $\mathrm{NaHCO}_{3}$ & Sigma & S-5761 & $0,2106 \mathrm{~g}$ \\
\hline $\mathrm{Na} \mathrm{Lactato}$ & Sigma & L-7900 & $0,0370 \mathrm{~g}$ \\
\hline Ácido Pirúvico & Sigma & P-3662 & $0,0034 \mathrm{~g}$ \\
\hline L-glutamina & Sigma & G-8540 & $0,0146 \mathrm{~g}$ \\
\hline $\mathrm{MgCl}_{2} 7 \mathrm{H}_{2} \mathrm{O}$ & Sigma & M-2393 & $0,0098 \mathrm{~g}$ \\
\hline $\mathrm{CaCl}_{2}$ & Sigma & C-5670 & $0,0252 \mathrm{~g}$ \\
\hline
\end{tabular}

Filtrar em 0,22 $\mu \mathrm{m}$

- Meio SOFaa (Uso)

\begin{tabular}{c|c|c|c}
\hline Reagentes & Fabricante & Catálogo & $\mathbf{5 m l}$ \\
\hline Meio SOF estoque & & & $4,6 \mathrm{ml}$ \\
\hline Aminoácidos essenciais & Sigma & M-5550 & $0,100 \mathrm{ml}$ \\
\hline Aminoácidos não essenciais & Sigma & M-7145 & $0,050 \mathrm{ml}$ \\
\hline Soro Fetal Bovino & Gibco & $16140-014$ & $0,250 \mathrm{ml}$ \\
\hline
\end{tabular}

Preparar na hora do uso 


\section{ANEXO D - Soluções para teste SCSA}

- Tampão TNE

\begin{tabular}{c|c|c|c}
\hline Reagente & Fabricante & Catálogo & $\mathbf{5 0 0 m l}$ \\
\hline Tris-HCl 0,01M & Fluka & 93363 & \\
\hline $\mathrm{NaCl} 0,15 \mathrm{M}$ & Sigma & S-5886 & \\
\hline EDTA 1mM & Sigma & E-5134 & \\
\hline Água destilada & & & $500 \mathrm{ml}$ \\
\hline
\end{tabular}

Solução pH 7.4

- Solução detergente ácida

\begin{tabular}{|c|c|c|c|}
\hline Reagente & Fabricante & Catálogo & $500 \mathrm{ml}$ \\
\hline $\mathrm{HCl} 0,08 \mathrm{M}$ & Merck & K24537117 & \\
\hline $\mathrm{NaCl} 0,15 \mathrm{M}$ & Sigma & S-5886 & \\
\hline Triton $\mathrm{x}-1000,1 \%$ & Sigma & $X-100$ & \\
\hline Água destilada & & & $500 \mathrm{ml}$ \\
\hline
\end{tabular}

Solução pH 1.2

- Solução de Laranja de Acridina (L.A) - estoque

\begin{tabular}{c|c|c|c}
\hline Reagente & Fabricante & Catálogo & 10ml \\
\hline Laranja de Acridina & Sigma & A-6014 & $60 \mu \mathrm{g}$ \\
\hline Água destilada & & & $10 \mathrm{ml}$ \\
\hline
\end{tabular}

- Solução de Laranja de Acridina - Uso

\begin{tabular}{c|c|c|c}
\hline Reagente & Fabricante & Catálogo & $\mathbf{1 2 0} \mathbf{m l}$ \\
\hline Ácido cítrico & Sigma & C-1909 & $2,52 \mathrm{~g}$ \\
\hline $\mathrm{Na}_{2} \mathrm{HPO}_{4}$ & Sigma & $\mathrm{S}-5136$ & $3,408 \mathrm{~g}$ \\
\hline EDTA & Sigma & $\mathrm{E}-5134$ & $0,04466 \mathrm{~g}$ \\
\hline $\mathrm{NaCl}$ & Sigma & S-5886 & $1,05192 \mathrm{~g}$ \\
\hline L.A estoque & & & $720 \mu \mathrm{l}$ \\
\hline Água destilada q.s.p. & & & $120 \mathrm{ml}$
\end{tabular}

Solução pH 6.0 
ANEXO E - Soluções para ensaio de TUNEL

- Solução de PBS 0.2M

\begin{tabular}{c|c|c|c}
\hline Reagentes & Fabricante & Catálogo & 1L \\
\hline $\mathrm{K}_{2} \mathrm{HPO}_{4} 0.2 \mathrm{M}$ & Sigma & $\mathrm{P}-5655$ & $34,83 \mathrm{~g}$ \\
\hline $\mathrm{NaCl}$ & Sigma & $\mathrm{S}-5886$ & $9 \mathrm{~g}$ \\
\hline Água Milli Q & & & $1 \mathrm{~L}$ \\
\hline
\end{tabular}

pH 7.4

- Solução de PBS 10mM

\begin{tabular}{c|c|c|c}
\hline Reagentes & Fabricante & Catálogo & 1L \\
\hline $\mathrm{K}_{2} \mathrm{HPO}_{4} 10 \mathrm{mM}$ & Sigma & $\mathrm{P}-5655$ & $1,742 \mathrm{~g}$ \\
\hline $\mathrm{NaCl}$ & Sigma & $\mathrm{S}-5886$ & $9 \mathrm{~g}$ \\
\hline Água Milli Q & & & $1 \mathrm{~L}$ \\
\hline
\end{tabular}

pH 7.4

- Solução de PBS-PVP

\begin{tabular}{c|c|c|c}
\hline Reagentes & Fabricante & Catálogo & 1L \\
\hline PBS 10mM & & & $1000 \mathrm{ml}$ \\
\hline Polivinilpirrolidona (PVP) & Sigma & P-0930 & $1 \mathrm{~g}$ \\
\hline
\end{tabular}

- Solução de Hidróxido de Sódio 2N

\begin{tabular}{c|c|c|c}
\hline Reagentes & Fabricante & Catálogo & 1L \\
\hline $\mathrm{NaOH} 2 \mathrm{~N}$ & Synth & $\mathrm{H} 1017.01 . \mathrm{AH}$ & $80 \mathrm{~g}$ \\
\hline Água Milli Q & & & $1 \mathrm{~L}$ \\
\hline
\end{tabular}

- Solução de Paraformaldeído 8\% (estoque)

\begin{tabular}{c|c|c|c}
\hline Reagentes & Fabricante & Catálogo & 1L \\
\hline Paraformaldeído & EMS & 19210 & $8 \mathrm{~g}$ \\
\hline Água Milli $\mathrm{Q}\left(55-60^{\circ} \mathrm{C}\right)$ & & & $1 \mathrm{~L}$ \\
\hline
\end{tabular}

* adicionar algumas gotas de $\mathrm{NaOH} 2 \mathrm{~N}$ até a solução ficar incolor. Filtrar $(0,22 \mu \mathrm{m}) \mathrm{e}$ estocar a $-20^{\circ} \mathrm{C}$

- Solução de Paraformaldeído 4\% (uso)

* fazer uma solução 1:1 de paraformaldeído 8\% e PBS 0.2M no momento do uso. 
- Solução de Permeabilização

\begin{tabular}{c|c|c|c}
\hline Reagentes & Fabricante & Catálogo & $\mathbf{2 0 0 m l}$ \\
\hline Triton X-100 0,5\% & Sigma & X-100 & $1 \mathrm{ml}$ \\
\hline Solução de Citrato de Sódio 0,1\% & & & $199 \mathrm{ml}$ \\
\hline
\end{tabular}

- Solução de citrato de sódio $0,1 \%$

\begin{tabular}{c|c|c|c}
\hline Reagentes & Fabricante & Catálogo & 200ml \\
\hline Citrato de Sódio & Sigma & S-4641 & $2 \mathrm{~g}$ \\
\hline Água MilliQ & & & $200 \mathrm{ml}$ \\
\hline
\end{tabular}

- Solução de DNase (50U/ml)

\begin{tabular}{c|c|c|c}
\hline Reagentes & Fabricante & Catálogo & $\mathbf{1 0 0 \mu l}$ \\
\hline DNase I (RNase free) & BioLabs & M0303S & $2,5 \mu \mathrm{l}$ \\
\hline PBS-PVP & & & $97,5 \mu \mathrm{l}$ \\
\hline
\end{tabular}

* preparar a solução apenas no momento do uso

- Solução de Hoechst $33342(5 \mu \mathrm{g} / \mathrm{ml})$ - Estoque

\begin{tabular}{c|c|c|c}
\hline Reagentes & Fabricante & Catálogo & 1ml \\
\hline Hoechst 33342 & Sigma & B-2261 & $5 \mu \mathrm{g}$ \\
\hline PBS & Nutricell & 01.002 .1000 & $1 \mathrm{ml}$ \\
\hline
\end{tabular}

Estocar a $-20^{\circ} \mathrm{C}$

- Solução de Hoechst 33342 - Uso

\begin{tabular}{c|c|c|c}
\hline Reagentes & Fabricante & Catálogo & $\mathbf{1 m l}$ \\
\hline Solução de Hoechst 33342 estoque & & & $1 \mu \mathrm{l}$ \\
\hline PBS-PVP & & & $1 \mathrm{ml}$ \\
\hline
\end{tabular}

* Preparar apenas no momento do uso

- Solução de DABCO

\begin{tabular}{c|c|c|c}
\hline Reagentes & Fabricante & Catálogo & $\mathbf{1 0 m l}$ \\
\hline 1,4-Diazabicyclo [2.2.2]octane (DABCO) & Sigma & $\mathrm{D}-2522$ & $0,23 \mathrm{~g}$ \\
\hline Tris 0.5M, pH 8.0 & Fluka & 93363 & $0,4 \mathrm{ml}$ \\
\hline Glicerol & Sigma & $\mathrm{G}-5516$ & $5 \mathrm{ml}$ \\
\hline Água destilada & & & $4,6 \mathrm{ml}$ \\
\hline
\end{tabular}

Manter a $4^{\circ} \mathrm{C}$, abrigado da luz. 
ANEXO F - Soluções para ensaio COMETA

- Solução de TBE 1X

\begin{tabular}{c|c|c|c}
\hline Reagentes & Fabricante & Catálogo & 1L \\
\hline Trizma Base 0,089M & Fluka & 93362 & \\
\hline Ácido Bórico 0,089M & Carlo Erba & 402766 & \\
\hline EDTA 0,002M & Sigma & E-5134 & \\
\hline Água destilada q.s.p & & & $1 \mathrm{~L}$ \\
\hline
\end{tabular}

- Agarose Normal Melting (NM) 1\%

\begin{tabular}{c|c|c|c}
\hline Reagentes & Fabricante & Catálogo & $\mathbf{1 0 0} \mathbf{m l}$ \\
\hline Agarose Normal Menting & Sigma & A-9539 & $1 \mathrm{~g}$ \\
\hline TBE 1X & & & $100 \mathrm{ml}$ \\
\hline
\end{tabular}

Manter a $4^{\circ} \mathrm{C}$

- Agarose Low Melting (LM) 0,75\%

\begin{tabular}{c|c|c|c}
\hline Reagentes & Fabricante & Catálogo & $\mathbf{1 0 0 m l}$ \\
\hline Agarose Low Melting & Sigma & A-4018 & $0,75 \mathrm{~g}$ \\
\hline TBE 1X & & & $100 \mathrm{ml}$ \\
\hline
\end{tabular}

- EDTA-Na $1 \mathrm{M}$

\begin{tabular}{c|c|c|c}
\hline Reagentes & Fabricante & Catálogo & 1L \\
\hline EDTA & Sigma & E-5134 & $372,24 \mathrm{~g}$ \\
\hline Água MilliQ & & & $1 \mathrm{~L}$ \\
\hline
\end{tabular}

pH 7.8

- Tris-HCl 1M

\begin{tabular}{c|c|c|c}
\hline Reagentes & Fabricante & Catálogo & 100ml \\
\hline Tris-HCl & Fluka & 93363 & $15,76 \mathrm{~g}$ \\
\hline Água MilliQ & & & $100 \mathrm{ml}$ \\
\hline
\end{tabular}

pH 7.8

- $\mathrm{NaCl} 5 \mathrm{M}$

\begin{tabular}{c|c|c|c}
\hline Reagentes & Fabricante & Catálogo & 1L \\
\hline $\mathrm{NaCl}$ & Sigma & S-5886 & $292,2 \mathrm{~g}$ \\
\hline Água MilliQ & & & $1 \mathrm{~L}$ \\
\hline
\end{tabular}


- DTT 1M

\begin{tabular}{c|c|c|c}
\hline Reagentes & Fabricante & Catálogo & $\mathbf{4 m l}$ \\
\hline Dithiothreitol (DTT) & Invitrogen & $15508-013$ & $0,617 \mathrm{~g}$ \\
\hline Água MilliQ & & & $4 \mathrm{ml}$ \\
\hline
\end{tabular}

Aliquotar e manter a $-20^{\circ} \mathrm{C}$

- Solução de ressuspensão da proteinase K

\begin{tabular}{c|c|c|c}
\hline Reagentes & Fabricante & Catálogo & 10ml \\
\hline Tris-HCl 10mM; $\mathrm{pH} 7.5$ & Fluka & 93363 & \\
\hline $\mathrm{CaCl}_{2} 20 \mathrm{mM}$ & Sigma & C-5670 & \\
\hline Glicerol & Sigma & G-5516 & $5 \mathrm{ml}$ \\
\hline Água MilliQ q.s.p & & & $10 \mathrm{ml}$ \\
\hline
\end{tabular}

pH 7.5

- Solução de Proteinase K (2mg/ml)

\begin{tabular}{c|c|c|c}
\hline Reagentes & Fabricante & Catálogo & $\mathbf{2 m l}$ \\
\hline Proteinase K & Invitrogen & $25530-015$ & $4 \mathrm{mg}$ \\
\hline Solução de ressuspensão & & & $2 \mathrm{ml}$ \\
\hline
\end{tabular}

Aliquotar e manter a $-20^{\circ} \mathrm{C}$

- Solução de Cloreto de cálcio hidratado 0,2M

\begin{tabular}{c|c|c|c}
\hline Reagentes & Fabricante & Catálogo & $\mathbf{1 0 m l}$ \\
\hline $\mathrm{CaCl}_{2}$ & Sigma & C-5670 & $0,29404 \mathrm{~g}$ \\
\hline Água MilliQ & & & $10 \mathrm{ml}$ \\
\hline
\end{tabular}

- Poli-L-Lisina 0,01\%

\begin{tabular}{c|c|c|c}
\hline Reagentes & Fabricante & Catálogo & $\mathbf{2 0 0 \mathrm { ml }}$ \\
\hline Poly-L-Lysine & Sigma & P-8920 & $20 \mathrm{ml}$ \\
\hline Água destilada & & & $180 \mathrm{ml}$ \\
\hline
\end{tabular}

Manter $\mathbf{a}-4^{\circ} \mathrm{C}$

- Solução de Lise I

\begin{tabular}{c|c|c|c}
\hline Reagentes & Fabricante & Catálogo & $\mathbf{1 L}$ \\
\hline $\mathrm{EDTA}^{\mathrm{Na}} \mathrm{H}_{2} 100 \mathrm{mM}$ & & & \\
\hline Tris $\mathrm{HCl} 10 \mathrm{mM}$ & Fluka & 93363 & \\
\hline $\mathrm{NaCl} 2,5 \mathrm{M}$ & Sigma & S-5886 & \\
\hline Proteinase K $(20 \mu \mathrm{g} / \mathrm{mL})$ & Invitrogen & $25530-015$ & \\
\hline Água MilliQ & & & $1 \mathrm{~L}$ \\
\hline
\end{tabular}

Manter $\mathbf{a}-4^{\circ} \mathrm{C}$ 
- Solução de Lise II

\begin{tabular}{c|c|c|c}
\hline Reagentes & Fabricante & Catálogo & 1L \\
\hline EDTA-Na $100 \mathrm{mM}$ & & & \\
\hline Tris HCl 10mM & Fluka & 93363 & \\
\hline $\mathrm{NaCl} 2,5 \mathrm{M}$ & Sigma & S-5886 & \\
\hline Triton X-100 4\% & Sigma & X-100 & \\
\hline DTT 40mM, pH 11.0 & Invitrogen & $15508-013$ & \\
\hline Água MilliQ & & & $1 \mathrm{~L}$ \\
\hline
\end{tabular}

Manter $\mathbf{a}-4^{\circ} \mathrm{C}$

- Solução alcalina de eletroforese

\begin{tabular}{c|c|c|c}
\hline Reagentes & Fabricante & Catálogo & 1L \\
\hline $\mathrm{NaOH} 300 \mathrm{mM}$ & Synth & H1017.01.AH & \\
\hline EDTA-Na $1 \mathrm{mM}$ & & & \\
\hline Água MilliQ & & & $1 \mathrm{~L}$ \\
\hline
\end{tabular}

$\mathrm{pH}>13.0$

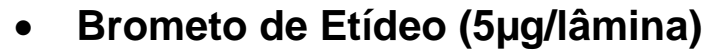

\begin{tabular}{c|c|c|c}
\hline Reagentes & Fabricante & Catálogo & \\
\hline Brometo de etídeo & BioAgency & $01-0433 \mathrm{~N}$ & $0,5 \mu \mathrm{l}$ \\
\hline TBE 1X & & & $1,5 \mathrm{ml}$ \\
\hline
\end{tabular}

* solução para coloração de cada lâmina 
ANEXO G - Soluções para ensaio de TBARS

- Sulfato de Ferro $4 \mathrm{mM}$

\begin{tabular}{c|c|c|c}
\hline Reagentes & Fabricante & Catálogo & $\mathbf{5 0 m l}$ \\
\hline Sulfato de Ferro & Sigma & F-8263 & $0,05560 \mathrm{~g}$ \\
\hline Água MilliQ & & & $50 \mathrm{ml}$ \\
\hline
\end{tabular}

Manter em temperatura ambiente e abrigado da luz

- Ascorbato $20 \mathrm{mM}$

\begin{tabular}{c|c|c|c}
\hline Reagentes & Fabricante & Catálogo & $\mathbf{5 0 m l}$ \\
\hline Ascobarto & Sigma & A-4034 & $0,17615 \mathrm{~g}$ \\
\hline Água MilliQ & & & $50 \mathrm{ml}$ \\
\hline
\end{tabular}

Manter em temperatura ambiente e abrigado da luz

- Ácido Tricloroacético 10\% (TCA 10\%)

\begin{tabular}{c|c|c|c}
\hline Reagentes & Fabricante & Catálogo & $\mathbf{1 ~ L}$ \\
\hline TCA 10\% & Sigma & T-9195 & $0,17615 \mathrm{~g}$ \\
\hline Água MilliQ q.s.p & & & $1 \mathrm{~L}$ \\
\hline
\end{tabular}

- Ácido Tiobarbitúrico (TBA 1\%)

\begin{tabular}{|c|c|c|c|}
\hline Reagentes & Fabricante & Catálogo & $100 \mathrm{ml}$ \\
\hline TBA $1 \%$ & Sigma & T-5500 & $1 \mathrm{~g}$ \\
\hline $\mathrm{NaOH} 0,05 \mathrm{~N}$ & Synth & $\mathrm{H} 1017.01 . \mathrm{AH}$ & $100 \mathrm{ml}$ \\
\hline
\end{tabular}

Preparar apenas no momento do uso 